DÍAZ, ALEJANDRA. "La experiencia de la mediación penal en Chile".

Polít. crim. Vol. 5, № 9 (Julio 2010), Art. 1, pp. 1-67.

[http://www.politicacriminal.cl/Vol_05/n_09/Vol5N9A1.pdf]

\title{
La Experiencia de la Mediación Penal en Chile ${ }^{1}$
}

\author{
Alejandra Díaz Gude \\ $\mathrm{PhD}$ in Law, University of Leeds \\ alediazgude@gmail.com
}

\section{Resumen}

El artículo analiza el desarrollo de la mediación penal en Chile, tanto desde un punto de vista de la teoría y el marco legal aplicable, como de su desarrollo práctico, e intenta a la vez articular una mirada histórica respecto de los movimientos socio-jurídicos que han surgido en Chile y que han cimentado la recepción y desarrollo de la mediación penal en el mismo. La autora identifica a la mediación penal como una práctica específica de justicia restaurativa, si bien muestra cómo en Chile, la asociación entre ambos conceptos no es pacífica. Finaliza con una reflexión que intenta explicar el escaso nivel de desarrollo que han alcanzado estos procesos restaurativos en Chile, particularmente a partir de un análisis de los rasgos de la cultura legal chilena y de la implementación de la reforma al proceso penal en el país durante la última década.

\section{Palabras clave}

Justicia restaurativa, mediación penal, Chile, justicia penal, justicia penal juvenil, reparación víctimas,

\begin{abstract}
The article analyses the development of penal mediation in Chile, from a theoretical, legal and practical perspective. It also attempts to make a historical account of the socio-legal movements that have taken place in Chile and which have contribute to the reception and development of penal mediation therein. The author identifies penal mediation as a specific practice of restorative justice, although also showing that this association in Chile is not at all uncontested. It ends with a reflection about the reasons why restorative justice processes have had yet a marginal place in Chilean criminal justice system, exploring among those reasons, the features of Chilean legal culture and the implementation of the criminal procedure reform during the last decade.
\end{abstract}

\section{Key words}

Restorative justice, penal mediation, Chile, criminal justice, juvenile justice, reparation to victims.

\footnotetext{
${ }^{1}$ Deseo agradecer los valiosos comentarios y sugerencias realizados a este trabajo por los Prof. María Angélica Jiménez y Raúl Carnevali.
} 
DÍAZ, ALEJANDRA. "La experiencia de la mediación penal en Chile".

\section{Introducción}

Este artículo intenta esbozar el panorama o desarrollo de la mediación penal y la justicia restaurativa en Chile, tanto desde un punto de vista práctico, como teórico. Primero, se presenta el concepto de justicia restaurativa y mediación penal que sustenta el presente análisis, y luego se exploran las diversas definiciones y percepciones sobre estos conceptos que surgen del movimiento que se ha dado en Chile. Luego, se analiza el marco legal que hace posible la mediación penal en Chile para ofensores adultos. A continuación, se articula una mirada acerca de los orígenes de la mediación penal en Chile, las iniciativas y proyectos implementados y la ideología que los ha permeado. En seguida, se analiza brevemente la experiencia de la mediación penal y la justicia restaurativa en el ámbito de la justicia juvenil. Finalmente, se esbozan algunas hipótesis que pueden explicar el particular desarrollo que ha tenido la justicia restaurativa y la mediación penal en Chile, finalizando con las conclusiones a este trabajo.

\section{Concepto de justicia restaurativa.}

La justicia restaurativa es un movimiento de carácter internacional cada vez más creciente de reforma a la justicia penal occidental, surgido básicamente en la cultura jurídica anglosajona, pero que ha comenzado a extenderse paulatinamente hacia otros países de Europa, África, Oceanía y, recientemente, a Latinoamérica. El criminólogo australiano John Braithwaite ${ }^{2}$ ha afirmado que la justicia restaurativa constituye el principal movimiento de reforma a la justicia criminal del período de los noventa y entrando al nuevo milenio.

Es también una teoría en formación, y un conjunto de prácticas diversas surgidas en distintas partes del mundo, unidas por algunos elementos o principios comunes.

Una definición generalmente aceptada de justicia restaurativa, es la proporcionada por Tony Marshall, ${ }^{3}$ quien señala: "la justicia restaurativa es un proceso a través del cual las partes que se han visto involucradas y/o que poseen un interés en un delito en particular, resuelven de manera colectiva la manera de lidiar con las consecuencias inmediatas de éste y sus repercusiones para el futuro." Este concepto enfatiza dos principios o ideas centrales de la justicia restaurativa. Primero, se refiere a la inclusión de nuevos actores o partes en la resolución del conflicto jurídico-penal: la víctima, el autor, y otras personas afectadas por el delito como las familias de las partes y los miembros de la comunidad. En esta noción subyace la idea de que el delito no es sólo un problema entre el Estado y el imputado sino que, antes que nada, y como ha afirmado Nils Christie, ${ }^{4}$ es un conflicto entre las partes directamente afectadas por el delito, conflicto que ha sido históricamente usurpado a sus dueños por los profesionales de la justicia penal formal. Segundo, este concepto enfatiza la idea de la justicia restaurativa como un proceso participativo y deliberativo, que reúne -

\footnotetext{
${ }^{2}$ BRAITHWAITE, John, "Restorative justice" en: TONRY, Michael (Ed.), The Handbook of Crime and Punishment, Oxford: Oxford University Press, 1998, pp. 323-44.

${ }^{3}$ MARSHALL, T.F., Restorative Justice. An Overview. Home Office, 1999.

${ }^{4}$ CHRISTIE, Nils, "Conflicts as property", The British Journal of Criminology, vol. 17, nº 1 (1977), pp. 1-14.
} 
Polít. crim. Vol. 5, No 9 (Julio 2010), Art. 1, pp. 1-68.

[http://www.politicacriminal.cl/Vol_05/n_09/Vol5N9A1.pdf]

ojalá en un mismo lugar y mediante un encuentro personal- a las partes directamente afectadas por el delito, a fin de que, a través del diálogo y la comunicación de hechos e intercambio de emociones, puedan llegar a un acuerdo mutuamente satisfactorio sobre cómo reparar el daño originado por el delito.

A la visión de Marshall se le ha criticado el hecho de no enfatizar suficientemente los resultados de carácter restaurativo, prestando demasiada atención a los procesos restaurativos. Así, Bazemore y Walgrave ${ }^{5}$ proporcionan una definición distinta pero complementaria a la de Marshall, señalando que ella constituye "toda acción orientada principalmente a hacer justicia a través de la restauración o reparación del daño causado por el delito." De esta definición surgen cuatro preguntas que orientan la reflexión teórica acerca de la justicia restaurativa: (1) ¿cuál es el daño causado por el delito?, (2) ¿quién (y qué) debe considerarse como víctima del delito?, (3) ¿cómo puede ese daño ser restaurado o reparado?, (4) ¿qué es la justicia y cómo puede obtenerse?

La tercera de estas preguntas apunta precisamente a la distinción entre procesos y resultados restauradores. Para Walgrave ${ }^{6}$ y otros autores, constituyen justicia restaurativa tanto los resultados reparadores, incluyendo la restitución, compensación, reparación, reconciliación y disculpas, como los procesos restaurativos, que incorporan mediación (in)directa, conferencias comunitarias, entre otras opciones. En cuanto a éstos últimos, se señala que su característica distintiva radica en la voluntariedad de la participación de las partes.

El concepto de Walgrave plantea una visión maximalista de justicia restaurativa, que apunta a constituirla en la principal respuesta jurídico-penal al delito, puesto que Walgrave considera que la justicia restaurativa también tiene lugar tratándose de procesos coercitivos con intervención judicial, y no sólo en los niveles informales de resolución del conflicto al interior de la comunidad. De no aceptar la co-existencia entre justicia restaurativa y procesos coercitivos, la justicia restaurativa quedaría siempre relegada a una justicia marginal dentro de los sistemas de justicia criminal formales. Sin embargo, esto plantea el desafío de pensar en formas de interacción entre la justicia restaurativa y la coerción, sin traicionar los propios principios y valores de la primera. Desde ya, debe aceptarse que cuando la justicia restaurativa se desarrolle en el marco de procesos coercitivos judiciales, lo propiamente restaurativo radicará en los resultados vgr.: reparación, restitución, etc.) y no tanto en los procesos, por cuanto estos últimos requerirían del elemento de voluntariedad en la participación. Una respuesta restaurativa de este tipo estaría constituida, por ejemplo, por los servicios en beneficio de la comunidad impuestos por una autoridad judicial. En todo caso, este es un tema bastante debatido al interior de la justicia restaurativa.

\footnotetext{
${ }^{5}$ BAZEMORE, G.; WALGRAVE, L., Restorative Juvenile Justice: Repairing the Harm of Youth Crime, Monsey: Criminal Justice Press, 1999, p. 48.

${ }^{6}$ WALGRAVE, L., "Extending the Victim Perspective Towards a Systemic Restorative Justice Alternative" en: CRAWFORD, A.; GOODEY, J. (Eds.), Integrating a Victim Perspective Within Criminal justice: International Debates, Aldershot: Ashgate, 2000, pp. 253-83.
} 
DÍAZ, ALEJANDRA. "La experiencia de la mediación penal en Chile".

En este artículo, se adopta la definición de Marshall $^{7}$ de justicia restaurativa, complementada con la de Walgrave ${ }^{8}$ aceptando o adhiriendo a la tesis maximalista, que cree posible la coexistencia entre justicia restaurativa y procesos judiciales coercitivos.

Pero, además, se complementan los dos conceptos anteriores con la definición de justicia restaurativa en base a valores o principios, proporcionada por Van Ness y Strong. ${ }^{9}$ Para los autores, cuatro son los valores básicos de la justicia restaurativa: a) Encuentro; b) Reparación; c) Reintegración, y d) Participación o Inclusión.

a) Encuentro: consiste en el encuentro personal y directo entre víctimas, autores $y / u$ otras personas que puedan servir de apoyo a las partes y que constituyen sus comunidades de cuidado. ${ }^{10}$ Además, requiere que en lo posible se den tres elementos adicionales al encuentro entre los participantes, a saber: (1) narrativa, es decir, que las partes relaten sus propias historias del conflicto, desde su propia subjetividad; (2) las emociones, esto es, que las partes muestren sus emociones durante el encuentro; finalmente, (3) entendimiento mutuo, que implica que las partes hablen a la vez que escuchen al otro, y que lo hagan con entendimiento, de manera tal que pueda surgir empatía entre ellas. Los elementos de encuentro, narrativa y emociones conducen al entendimiento y, a su vez, cuando hay entendimiento, las posibilidades de alcanzar un acuerdo que satisfaga las necesidades de todos los involucrados y que sea practicable o realista se incrementan.

b) Reparación: es la forma restaurativa por medio de la cual el sistema de justicia responde al daño causado a la víctima. Incluye restitución (devolución de la propiedad, pago monetario y trabajo en beneficio de la víctima) y otras sanciones reparativas que requieren que el autor asuma su responsabilidad por el hecho delictivo. Para Van Ness y Strong ${ }^{11}$ la reparación debe ir primero que nada en beneficio de la víctima concreta y real, y luego, dependiendo de las circunstancias, puede beneficiar a víctimas secundarias y a la comunidad.

c) Reintegración: se refiere a la reintegración tanto de la víctima como del autor en la comunidad. Esto significa no sólo tolerar la presencia de la persona en el seno de la comunidad sino que, más aún, contribuir a su reingreso como una persona integral, cooperadora y productiva. La necesidad de reintegración surge de la experiencia común de alienación y estigmatización que sufren víctimas y ofensores y, por tanto, requiere la superación de este estado de alienación. La comunidad tiene en la perspectiva restauradora un rol fundamental que cumplir en ayudar a víctimas y ofensores a reintegrarse en la misma. Para las víctimas esto puede consistir en tener acceso a servicios de ayuda a sus necesidades materiales, sicológicas y médicas. La reintegración es particularmente

\footnotetext{
${ }^{7}$ MARSHALL, cit. nota $\mathrm{n}^{\circ} 3$.

${ }^{8}$ MARSHALL, cit. nota ${ }^{\circ} 3$.

${ }^{9}$ VAN NESS, D.; STRONG, K.H., Restoring Justice, Cincinnati, Ohio: Anderson Publishing, 1997, p. 92.

${ }^{10}$ BRAITHWAITE, J., Crime, Shame and Reintegration, Cambridge: Cambridge University Press, 1989.

${ }^{11}$ VAN NESS/STRONG, Restoring Justice, cit nota ${ }^{\circ}$ 9, p. 92.
} 
Polít. crim. Vol. 5, No 9 (Julio 2010), Art. 1, pp. 1-68.

[http://www.politicacriminal.cl/Vol_05/n_09/Vol5N9A1.pdf]

importante para el ofensor cuando ya ha sido sancionado y sobre todo cuando sale de prisión.

d) Participación o Inclusión: se destacan las oportunidades de cada parte para involucrarse de forma directa y completa en todas las etapas de encuentro, reparación y reintegración. Requiere de procesos que transformen la inclusión de las partes en algo relevante y valioso, y que aumenten las posibilidades de que dicha participación sea voluntaria. ${ }^{12}$

Estos valores pueden ser realizados en distintas etapas de los procedimientos penales, y bajo diversas prácticas. Permiten, por tanto, el diseño de agendas progresivas de incorporación de valores restaurativos en los sistemas legales, lo cual adquiere especial relevancia tratándose de sistemas de justicia que se encuentran en una fase inicial de implementación de la justicia restaurativa, como es el caso de Chile.

Por su parte, se entiende a la mediación penal en este artículo, como una técnica o práctica específica de justicia restaurativa, que entronca con distintas tradiciones, siendo las más conocidas, la tradición Cristiana y sus modelos de Reconciliación Víctima e Infractor (en adelante, VORP), y los modelos de mediación penal desarrollados en la Tradición Continental Europea, como Francia, España y Alemania. Si bien ellas pueden estar inspiradas por objetivos y principios diversos, un aspecto común es la centralidad que conceden a la relación bilateral entre víctima e infractor, y la ausencia o menor participación de la comunidad en dichos modelos, comparado con las prácticas de conferencias comunitarias o del grupo familiar. En este sentido, y siguiendo a McCold y Wachtel, ${ }^{13}$ la mediación penal es una práctica "mayormente restaurativa", pues involucra de manera activa y significativa en el proceso sólo a la víctima y al ofensor, pero no a la comunidad. Una definición útil de mediación penal a estos efectos, es la proporcionada por Gema Varona: "Es un proceso de comunicación en el que la víctima y el infractor llegan a un acuerdo, con ayuda de un tercero neutral, que supone una reparación de los daños causado, materiales e inmateriales, y que en su caso, afectará el proceso penal entendiendo éste en sentido amplio-". ${ }^{14}$ Este concepto tiene la virtud de su amplitud, en el sentido de que no excluye a ninguna tradición de mediación en particular, y a la vez, enfatiza los elementos propiamente penales del modelo, para diferenciarlo de la mediación como técnica de resolución de conflictos en los ámbitos de familia, civil, o laboral.

\section{Marco legal aplicable.}

En esta sección se analizará el marco legal que hace posible la incorporación de la mediación penal en Chile, analizando la normativa aplicable específicamente en el ámbito

\footnotetext{
${ }^{12}$ VAN NESS/STRONG, Restoring Justice, cit nota ${ }^{\circ}$ 9, p. 35.

${ }^{13}$ McCOLD, P.; WACHTEL, T., "Restorative Justice Theory Validation", ponencia presentada en la Fourth International Conference on Restorative Justice for Juveniles, Tübingen, Alemania, 1 a 4 de Octubre de 2000. Versión en español: "En busca de un paradigma, una teoría sobre justicia restaurativa", Revista EForum, Agosto 12 (2003), en: http://www.restorativepractices.org

14 VARONA, G., La mediación reparadora como estrategia de control social. Una perspectiva criminológica, Granada: Editorial Comares, 1998, p. 2.
} 
DÍAZ, ALEJANDRA. "La experiencia de la mediación penal en Chile".

de adultos, que es donde primero surge la posibilidad de incorporar mecanismos alternativos de resolución de conflictos de manera formal, en el contexto de la Reforma Procesal Penal, la cual, posteriormente, se extiende a la justicia penal juvenil. La mediación penal juvenil se analizará más adelante en este artículo (Titulo 5).

\subsection{Mediación Penal en Adultos.}

En Chile, la posibilidad del desarrollo de la mediación penal y la justicia restaurativa de manera formal se produjo a nivel legislativo, por primera vez, con la Reforma Procesal Penal, ${ }^{15}$ que comenzó a regir desde diciembre del año 2000 de manera gradual en distintas regiones del país, y que cambió el modelo inquisitivo de enjuiciamiento criminal vigente en Chile desde el Código de Procedimiento Penal de 1906, hacia un modelo acusatorio, con juicio oral, público y contradictorio. El nuevo Código Procesal Penal incorporó las llamadas Salidas Alternativas al Proceso Penal que constituyen formas de término anticipado al proceso, establecidas como excepción al principio de legalidad en la persecución penal, y que implican el reconocimiento por parte del Estado de la necesidad de establecer mecanismos de solución al conflicto penal distintos al proceso penal y la pena tradicionales. Estas Salidas Alternativas consisten básicamente en la Suspensión Condicional del Procedimiento y los Acuerdos Reparatorios. ${ }^{16}$ Además de las Salidas Alternativas, es posible desarrollar procesos de mediación penal en el marco del principio de oportunidad, que es una forma de término anticipado al proceso, facultativa del fiscal. Debido a que las mayores posibilidades de incorporación de la Justicia Restaurativa y la Mediación Penal en Chile se dan a través de los Acuerdos Reparatorios, se analizará básicamente esta institución $\mathrm{y}$, en menor detalle, la Suspensión Condicional del Procedimiento.

\subsubsection{Los Acuerdos Reparatorios.}

Los acuerdos reparatorios (en adelante, AR) son una clara manifestación de la incorporación en el derecho penal chileno del interés preponderante de la víctima en la obtención de la reparación de los daños causados por el delito, así como de la orientación del Derecho Penal y Procesal Penal hacia una diversidad de respuestas al conflicto jurídico penal, que constituyan alternativas a la pena y al proceso penal estatal. Asimismo, aunque en menor medida, los AR forman parte de los mecanismos de descongestión de los sistemas penales de tipo acusatorio que incorporan el principio de oportunidad en la persecución penal, posibilitando que muchos casos se resuelvan por vías más informales sin necesidad de incurrir en los costos de tiempo y recursos que supone llevar un caso a juicio.

\footnotetext{
${ }^{15}$ Si bien esta afirmación debe ser matizada pues en el sistema penal previo a la Reforma existían mecanismos legales que permitían llegar a formas de justicia negociada, aún cuando ésta no se identificara con la idea de la resolución alternativa de conflictos ni con la justicia restaurativa. Así, en los procesos ante el Servicio de Impuestos Internos y los tribunales aduaneros se daba pie para poder negociar la acción penal, y en los delitos por giro doloso de cheques.

${ }^{16}$ HORWITZ, M. I.; LÓPEZ, J., Derecho Procesal Penal Chileno, Tomo I, Santiago de Chile: Editorial Jurídica, 2002, pp. 448-52.
} 
Polít. crim. Vol. 5, No 9 (Julio 2010), Art. 1, pp. 1-68.

[http://www.politicacriminal.cl/Vol_05/n_09/Vol5N9A1.pdf]

Por ello, si bien ni en la ley ni en la historia de su establecimiento aparece una mención expresa a la justicia restaurativa, es posible afirmar que los acuerdos reparatorios incorporan valores que son propiamente restaurativos: la orientación hacia la reparación, la posibilidad de incluir a nuevos actores en el proceso penal, antes no considerados o mínimamente considerados (víctima, imputado y comunidad), y que sea posible la reintegración del ofensor y de la víctima en la comunidad. ${ }^{17}$

Los acuerdos reparatorios consisten en un acuerdo entre víctima e imputado, prestado en forma libre y con pleno conocimiento de sus derechos, mediante el cual el imputado se compromete a reparar a la víctima de una forma que resulte satisfactoria para ésta, y que es aprobado por el juez de garantía, produciendo la extinción de la responsabilidad penal una vez que el acuerdo se encuentra cumplido (Art. 241 del Código Procesal Penal). La doctrina y jurisprudencia han entendido que esta reparación puede ser material o simbólica y consistir, incluso, en una disculpa.

Proceden respecto de ciertos y determinados delitos, cuales son: hechos que afecten bienes jurídicos disponibles de carácter patrimonial ${ }^{18}$ (básicamente delitos contra la propiedad sin violencia contra las personas); lesiones menos graves, y delitos culposos, incluyéndose entre éstos últimos, a los cuasidelitos de homicidio u homicidio culposo.

La oportunidad para celebrarlos es con posterioridad a la "formalización de la investigación", es decir, desde que se han formulado cargos al imputado, y hasta la audiencia de preparación del juicio oral.

Los acuerdos reparatorios no implican aceptación de la responsabilidad penal por parte del imputado, sólo suponen la manifestación de su voluntad de poner término al caso por esta vía. Esto permite resguardar el principio de inocencia y el derecho al juicio, frente a las críticas formuladas en contra de estos mecanismos de descongestión procesal, consistentes en que por la vía de la amenaza de la sanción penal, se estaría presionando a las personas a aceptar culpabilidad. Con esta fórmula de aceptación de una forma alternativa de resolver el conflicto, que no implica necesariamente aceptación de culpabilidad, se resguarda, al menos en parte, ese principio. Por ello, la celebración de un acuerdo reparatorio no puede ser considerada como una condena ni configurar antecedentes penales respecto del imputado que acepta esta salida.

Otra garantía del derecho a ser presumido inocente se encuentra en el Art. 335 del Código Procesal Penal (en adelante, CPP), el cual consagra la "confidencialidad" de los acuerdos, al señalar: "No se podrá invocar, dar lectura ni incorporar como medio de prueba al juicio oral ningún antecedente que dijere relación con la proposición, discusión, aceptación,

\footnotetext{
${ }^{17}$ VAN NESS/STRONG, Restoring Justice, cit nota $n^{\circ} 9$.

${ }^{18} \mathrm{La}$ ley no define expresamente qué se entiende por "bienes jurídicos disponibles de carácter patrimonial", de manera que esto da pie para el desarrollo de jurisprudencia que permita ir llenándolo de contenido (Ver HORWITZ/LÓPEZ, Derecho Procesal Penal Chileno, cit. nota ${ }^{\circ}$ 16, p. 571). El Fiscal Nacional ha dictado un Oficio en el cual señala los delitos que son susceptibles de acuerdo reparatorio, indicando cuándo los fiscales deberán promoverlo, evaluar con atención su procedencia, y derechamente oponerse a él (Oficio FN $\left.\mathrm{N}^{\circ} 38\right)$.
} 
DÍAZ, ALEJANDRA. "La experiencia de la mediación penal en Chile".

procedencia, rechazo o revocación de una suspensión condicional del procedimiento, de un acuerdo reparatorio o de la tramitación de un procedimiento abreviado". Por su parte, el artículo 415 del CPP hace extensible este principio de confidencialidad a la no mención de los antecedentes sobre acuerdos reparatorios en el procedimiento abreviado. ${ }^{19}$ Sin embargo, un problema que se plantea en este caso es que el juez de garantía, que es quien da su aprobación o rechazo a los acuerdos, es también el juez que conduce posteriormente el procedimiento abreviado, así como el procedimiento simplificado ${ }^{20}$ de manera que, este juez, que presenció la audiencia de celebración de acuerdos, y en el evento de no haberlos aprobado por cualquier motivo, es el juez que posteriormente debe decidir el caso si éste va a procedimiento abreviado o simplificado, con lo cual, la protección legal de la presunción de inocencia y de la confidencialidad en la discusión de los acuerdos, pierde su eficacia. En la práctica, algunos jueces en estos casos se han inhabilitado para seguir conociendo del asunto, pero ello no está regulado expresamente.

El resguardo del principio de confidencialidad en la discusión o rechazo de los acuerdos es también un mecanismo que fomenta la participación en procesos de Resolución Alternativa de Conflictos (en adelante, RAC) o de mediación penal conducentes al acuerdo, pues si el ofensor o imputado supiera que si no llega a un acuerdo, el fiscal podría invocar en el juicio el hecho de que él/ella estuvo dispuesto a llegar a un acuerdo con la víctima o, incluso, que en el proceso de RAC confesó los hechos, ello sería un desincentivo a la participación del imputado en estos procesos.

La exigencia legal de aprobación judicial del AR, posibilita que el juez controle la existencia de los requisitos legales de procedencia del acuerdo, así como de ciertos derechos básicos de las partes. Así, el juez debe verificar que el acuerdo haya sido prestado libre y voluntariamente ${ }^{21}$ por las partes y que verse sobre los delitos para los cuales la ley lo autoriza. Pero, además, el juez puede negar la aprobación de los acuerdos reparatorios cuando existe "un interés público prevalente en la persecución penal" (Art. 241 inciso $3^{\circ}$ $\mathrm{CPP}$ ). La preponderancia del interés público en la persecución penal la puede decidir el juez de oficio, negando su aprobación al acuerdo, o a petición del Ministerio Público, quien se opondrá a su aprobación en la audiencia respectiva, invocando dicho interés público, en cuyo caso resolverá el juez. La ley señala que "se entenderá especialmente que concurre este interés si el imputado hubiere incurrido reiteradamente en hechos como los que se

${ }^{19}$ Este procedimiento establecido en la legislación procesal penal chilena es similar al plea bargain estadounidense.

${ }^{20}$ Se trata de un procedimiento más breve y sumario para delitos de menor gravedad, el cual se tramita ante el juez de garantía, a diferencia del juicio oral, que se tramita ante un tribunal oral de tres jueces.

${ }^{21}$ En la literatura sobre justicia restaurativa existe debate en cuanto a las formas de asegurar que ciertos derechos mínimos de las partes sean respetados en estos procesos, en la medida que, si bien ellos implican una alternativa al juicio penal y la pena, de todas maneras constituyen formas de intervención en la vida y derechos del ofensor, que son posibles, en gran medida, gracias a la amenaza de coerción que subyace a estos procesos, en el evento de que el ofensor se niegue a participar. Ello conduce a cuestionarse acerca de temas fundamentales como los derechos del debido proceso, y la legitimidad de los procesos restaurativos. Según Cormier (2000), la aprobación judicial de estas salidas es un mecanismo que permite asegurar la observancia de estos derechos mínimos, y en esa medida, puede señalarse que constituye una buena "técnica legislativa". Si bien, por otro lado, la desventaja es que formaliza a los procesos restaurativos. 
Polít. crim. Vol. 5, No 9 (Julio 2010), Art. 1, pp. 1-68.

[http://www.politicacriminal.cl/Vol_05/n_09/Vol5N9A1.pdf]

investigaren en el caso particular" (Art. 241 inciso $3^{\circ} \mathrm{CPP}$ ). De acuerdo al Oficio $\mathrm{N}^{\circ} 38 \mathrm{del}$ Fiscal Nacional de 21 de enero de 2003, que entrega criterios de actuación a los fiscales en relación a los acuerdos reparatorios, la reiteración se refiere a que el imputado haya sido condenado anteriormente por delitos de la misma especie que el hecho punible objeto del acuerdo reparatorio, debiendo considerarse delitos de la misma especie aquellos que afectan un mismo bien jurídico, de acuerdo al art. 351 inc. $4^{\circ}$ del CPP. ${ }^{22}$

De esta manera, podrían eventualmente celebrarse varios acuerdos reparatorios respecto de un mismo imputado, pero esto dependerá en gran medida de los criterios jurisprudenciales y de las políticas de persecución penal de la Fiscalía. El mismo Oficio 38 del Fiscal Nacional (en adelante, FN), luego de señalar que el concepto de "reiteración" utilizado en el art 241 CPP se refiere a condenas anteriores por delitos de la misma especia, aclara, en su numeral 11 que, en todo caso:

"El art. 241 inc. $3^{\circ}$ del CPP contempla especialmente un caso de interés público prevalente en la persecución penal, por lo tanto, pueden darse otras circunstancias donde se estime que concurre tal interés. Por ende, los fiscales podrán considerar que concurre un interés público prevalente cuando:

- Exista otro bien jurídico afectado por el delito objeto de acuerdo reparatorio, que sea de mayor entidad que el principalmente protegido por el tipo (v. gr.: delito de manejo en estado de ebriedad con resultado de lesiones menos graves).

- Exista constancia de haber llegado a acuerdo reparatorio por delitos de la misma especie al menos en dos oportunidades anteriores, según el registro previsto por el art. 246 del CPP." 23

De esta manera, el Oficio 38 deja entregado a criterio de los fiscales la posibilidad de considerar que concurre interés prevalente en la persecución penal cuando existen acuerdos reparatorios anteriores por delitos de la misma especie.

\footnotetext{
${ }^{22}$ El referido Oficio fundamenta esta interpretación en el siguiente razonamiento: "La exigencia de condenas anteriores se condice con el principio de inocencia, el cual se vería vulnerado de entender que esta norma alude a hechos anteriores de la misma especie que no hubieren sido objeto de sentencias condenatorias firmes. "Así, el hecho de considerar, para los efectos de evaluar la procedencia de los acuerdos reparatorios, como conductas anteriores hechos por los cuales no se ha sido condenado, pone en cuestión la vigencia de la presunción de inocencia ya que se impediría acceder a los acuerdos basados en hechos que no han sido formalmente probados y por los cuales el imputado no ha sido considerado culpable en un juicio previo" (Mauricio Duce, ob. cit., p. 165)".

${ }^{23}$ El Oficio 38 cita también la siguiente jurisprudencia: "En este sentido se ha pronunciado la Corte de Apelaciones de Temuco, respecto de un acuerdo reparatorio aprobado por el Juzgado de Garantía de Pucón (caso RUC N. . 3130-1): "Temuco, diez de abril de dos mil uno. VISTOS: Atendido el mérito de los antecedentes, en lo que consta que el imputado L. A. Q. H. registra una sola condena anterior por el delito de la misma especie, y que el art. 241 inc. 3 del Código Procesal Penal exige para la procedencia de acuerdos reparatorios que no exista un interés público prevalente, entendiéndose que concurre este interés si el imputado hubiere incurrido "reiteradamente" en hechos similares al que se investiga en la causa, circunstancia que como ya se dijo no concurre en la especie, puesto que existe un solo hecho anterior que afecte al imputado. Y Atendido lo dispuesto en la norma legal antes citada, se CONFIRMA la resolución pronunciada en la audiencia de veintitrés de marzo del presente en cuanto aprobó el acuerdo reparatorio en contra de todos los imputados, y ordenó sobreseimiento total y definitivo en esta causa" (Boletín del Ministerio Público, N. ${ }^{\circ}$ 3, Julio 2001)".
} 
DÍAZ, ALEJANDRA. "La experiencia de la mediación penal en Chile".

El Art. 246 CPP establece que el fiscal deberá llevar un registro especial en el cual dejará constancia de los casos en los cuales hubiere decretado la Suspensión Condicional del Procedimiento (en adelante, SCP) o aprobado un acuerdo reparatorio. Este registro tiene por objeto verificar si el imputado cumple las condiciones impuestas en la $\mathrm{SCP}$, o si reúne los requisitos para acogerse, en su caso, a una nueva SCP o un acuerdo reparatorio. De manera que este registro permite al fiscal evaluar si la existencia de acuerdo reparatorio o suspensión condicional del procedimiento previa, amerita o no oponerse a la aprobación de la salida alternativa de que se trate. La ley señala que el registro tiene carácter de reservado, sin perjuicio del derecho de la víctima a conocer la información relativa al imputado.

Como se señaló previamente, el cumplimiento del acuerdo produce la extinción de la responsabilidad penal del imputado, que debe ser declarada por el juez a través de la dictación del "sobreseimiento definitivo" de la causa. Con anterioridad a la Ley N²0.074 del año 2005, la extinción de la responsabilidad penal se producía al momento de la aprobación judicial del acuerdo, debiendo el juez dictar en ese momento el "sobreseimiento definitivo" de la causa, aunque no se hubiese cumplido todavía el acuerdo. Dado que en algunos casos había incumplimiento de los acuerdos ya aprobados judicialmente, y no era posible continuar con la persecución penal del imputado pues la acción penal ya se había extinguido, siendo sólo posible exigir el cumplimiento forzado de la obligación mediante un procedimiento de carácter civil seguido ante el juez de garantía, se decidió reformar esta salida procesal por la Ley $\mathrm{N}^{\circ} 20.074$ y se estableció que el juez dictaría el sobreseimiento definitivo de la causa, extinguiendo consiguientemente la responsabilidad penal del imputado, sólo una vez que se hubiesen cumplido las obligaciones contraídas por el imputado en el acuerdo reparatorio o se haya garantizado debidamente su pago a satisfacción de la víctima (Art. 242 inciso $1^{\circ} \mathrm{CPP}$ ).

Por último, si hay varios imputados en una causa, y sólo uno o algunos de ellos convienen un acuerdo reparatorio con la víctima, el sobreseimiento definitivo se decreta sólo respecto de aquéllos que hubieren concurrido al acuerdo. ${ }^{24}$

\section{a) Mecanismos autocompositivos para celebrar Acuerdos Reparatorios.}

La ley no se refiere expresamente a la forma o mecanismo de resolución de conflictos mediante la cual los Acuerdos Reparatorios podrán ser llevados a la práctica, limitándose a señalar que "la víctima y el imputado podrán convenir acuerdos reparatorios" y que el juez de garantía deberá aprobarlos en audiencia a la que citará a los intervinientes (Art. 241 del $\mathrm{CPP}$ ). De esta forma, el legislador no mencionó expresamente a la mediación penal en el marco de los acuerdos reparatorios. Pero, dada la naturaleza autocompositiva de los acuerdos reparatorios, nada impide que éstos se lleven a cabo a través de la mediación penal o de algunas de las diversas formas de resolución alternativa de conflictos existentes, siempre y cuando se cumpla con los demás requisitos legales. Además, al no prescribir la

\footnotetext{
${ }^{24}$ Se trata, jurídicamente, de un "sobreseimiento definitivo parcial", que extingue la responsabilidad penal sólo respecto de uno o más de los imputados en una causa.
} 
Polít. crim. Vol. 5, No 9 (Julio 2010), Art. 1, pp. 1-68.

[http://www.politicacriminal.cl/Vol_05/n_09/Vol5N9A1.pdf]

norma del artículo 241 CPP un determinado procedimiento para celebrar los acuerdos reparatorios, deja abierta la posibilidad de incorporar diversos mecanismos de resolución alternativa de conflictos en el marco de aquéllos, lo cual tiene la ventaja de posibilitar el desarrollo flexible de las prácticas de justicia restaurativa.

Cabe señalar que esta técnica legislativa ha demostrado ser útil en términos de facilitar el desarrollo de la justicia restaurativa en otros países. En efecto, la experiencia internacional indica que muchas prácticas de resolución alternativa de conflictos y justicia restaurativa que se han desarrollado en el ámbito penal, han tenido lugar precisamente basándose en disposiciones legales flexibles que han establecido el principio de oportunidad ${ }^{25}$ del fiscal en la persecución penal, sin que estas normas se hayan referido específicamente a un modelo determinado de resolución de conflictos. ${ }^{26}$ De manera que el hecho que la ley procesal penal no se refiera expresamente a la mediación penal, no es razón suficiente para que esta última no se desarrolle.

Actualmente, la mediación penal se ha desarrollado escasamente en el contexto de los AR desde que se instauró la reforma procesal penal. Si bien más adelante se hace referencia detallada a las diversas experiencias de mediación penal desarrolladas en Chile, puede señalarse que la forma más común de concretar los AR es a través del uso de diversas técnicas de RAC por parte de fiscales y defensores, así como por abogados querellantes cuando los hay (típicamente en delitos económicos).

\section{b) Procedencia de los AR en relación a determinados delitos.}

El Art. 241 CPP señala en qué delitos procede el AR. A su vez, el Fiscal Nacional ha entregado criterios de actuación a los fiscales en el Oficio 38 (2003), especificando respecto de qué delitos el fiscal favorecerá, evaluará con detención, o se opondrá a la aprobación de acuerdos reparatorios. Así, y a modo de ejemplo, el Oficio 38 señala que, respecto de delitos que afecten bienes jurídicos disponibles de carácter patrimonial, el fiscal:

- Favorecerá los AR en: hurtos, daños, estafas, giro fraudulento de cheques, entre otros.

- Evaluará con detención la procedencia de los AR en: robo con fuerza en lugar habitado y robo con fuerza en lugar no habitado, robo de cosas en bienes nacionales de uso público, violación no violenta de domicilio, delitos aduaneros, delitos tributarios, entre otros.

- Se opondrá a los AR, en los delitos de: robo por sorpresa, robo con violencia e intimidación, entre otros.

\footnotetext{
${ }^{25}$ Entendido no en el sentido restringido del artículo 170 del CPP, sino que en el sentido amplio y como es tratado por parte de la doctrina nacional y comparada (Véase HORWITZ/LÓPEZ, Derecho Procesal Penal Chileno, cit. nota $\mathrm{n}^{\mathrm{o}} 16, \mathrm{pp} .48-52$ ).

${ }^{26}$ Ver, por ejemplo, el caso francés, en CRAWFORD, Adam, "Justice de Proximité - The Growth of 'Houses of Justice and Victim/Ofender Mediation in France: A Very Un French Legal Response?", Social \& Legal Studies, vol. 9, No. 1 (2000), pp. 29- 53.
} 
DÍAZ, ALEJANDRA. "La experiencia de la mediación penal en Chile".

c) Caso especial de los delitos de violencia intrafamiliar.

En los primeros años de la reforma procesal penal, se celebraron acuerdos reparatorios para delitos que tenían, en su base, una relación de violencia intrafamiliar (se trataba, mayoritariamente de delitos de lesiones, cuasidelitos, y delitos contra la libertad e intimidad de las personas, siendo el delito de violación de morada el más común entre estos últimos). Sin embargo, la Ley $\mathrm{N}^{\mathrm{o}} 20.066$ de 7 de octubre de 2005, sobre violencia intrafamiliar, prohibió en su artículo 19 la procedencia de acuerdos reparatorios en los procesos por delitos constitutivos de violencia intrafamiliar. El legislador recogió en este sentido algunas de las críticas formuladas por organizaciones e instituciones de defensa de los derechos de la mujer en contra de la celebración de acuerdos reparatorios respecto de estos casos, planteando que la dinámica de la violencia intrafamiliar está configurada por ciclos de violencia caracterizados por períodos de violencia-reconciliación ${ }^{27}$-violencia, en la cual, además, la fase siguiente de violencia suele ser más severa que la anterior. De esta manera, el perdón y reconciliación que se podía dar en el marco de los acuerdos reparatorios podía formar parte de estos ciclos de violencia y abuso.

Sin perjuicio de que este es un tema complejo, y que cualquier decisión de política criminal al respecto debe ser objeto de un acabado análisis, estudio y debate, es preciso señalar que en la literatura comparada sobre justicia restaurativa existen propuestas que favorecen la aplicación de procesos restaurativos para abordar los casos de violencia intrafamiliar. ${ }^{28}$

\subsubsection{La Suspensión Condicional del Procedimiento.}

Otra "salida alternativa" al proceso penal que posibilita el desarrollo de la mediación penal, es la Suspensión Condicional del Procedimiento contemplada en el Art. 238 del CPP. Consiste en un acuerdo entre fiscal e imputado, asesorado este último por su defensor, ${ }^{29}$ por el cual se suspende la investigación y el procedimiento por un tiempo determinado, que puede ser entre 1 y 3 años según los Arts. 237 y 238 CPP, a cambio de que el imputado acepte cumplir ciertas obligaciones o condiciones que son aprobadas en audiencia por el juez de garantía. Si el imputado cumple las condiciones en el tiempo establecido, y no es objeto de una nueva formalización de la investigación por hechos distintos, se extingue la acción penal por los ilícitos que motivaron la investigación, debiendo el tribunal de oficio o a petición de parte dictar sobreseimiento definitivo. El sobreseimiento definitivo, al igual que en el caso de los acuerdos reparatorios, implica que el imputado queda sin antecedentes penales. Además, la SCP no supone aceptación de responsabilidad penal, sólo implica la

\footnotetext{
${ }^{27}$ La fase de reconciliación se conoce en la literatura especializada como "luna de miel".

${ }^{28}$ Para una propuesta de política criminal en Chile al respecto, así como una síntesis de los argumentos en pro y en contra de la aplicación de la justicia restaurativa en casos de violencia intrafamiliar, ver BLANCO, R.; DIAZ, A.; HESKIA, J.; ROJAS, H., Justicia Restaurativa: Marco Teórico, Experiencias Comparadas y Propuestas de Política Pública, Santiago de Chile: Universidad Alberto Hurtado, 2004, pp. 87 y ss.

${ }^{29}$ Pues la ley exige que en la audiencia de aprobación de la SCP esté presente el abogado defensor, como requisito de validez de la misma. La ley no exige la presencia del abogado defensor en la audiencia de aprobación de acuerdos reparatorios, sin perjuicio de que pueda estar presente y que lo usual será que así sea.
} 
Polít. crim. Vol. 5, No 9 (Julio 2010), Art. 1, pp. 1-68.

[http://www.politicacriminal.cl/Vol_05/n_09/Vol5N9A1.pdf]

voluntad del imputado de acordar esta salida. ${ }^{30}$ La presencia del defensor del imputado en la audiencia judicial de aprobación de la SCP, es un requisito de validez de la misma. En contraste, la ley no exige la presencia de abogado defensor en la audiencia de aprobación de los acuerdos reparatorios.

$\mathrm{Al}$ igual que los acuerdos reparatorios, la suspensión condicional del procedimiento tiene su origen en la necesidad de diversificar las respuestas penales, de manera de evitar los efectos y costos del juicio oral y la pena estatal tradicional, entregando respuestas más rápidas a la vez que menos desocializadoras para el infractor. También obedecen al reciente reconocimiento de la posición y derechos de las víctimas en el proceso penal, como lo refleja, en particular, la letra e) del Art 238 CPP que contempla como una de las posibles condiciones a imponer al imputado la de indemnizar a la víctima mediante el pago de una suma de dinero.

Sin embargo, los acuerdos reparatorios constituyen una salida alternativa que supone una mayor "descentralización" del poder punitivo estatal que la suspensión condicional del procedimiento, entendiendo "descentralización" en el sentido propuesto por Nils Christie (1977), según el cual a través de formas de justicia informal ${ }^{31}$ y autocompositivas, el Estado le "devuelve" a las partes la propiedad sobre su conflicto. Esto se refleja, en primer lugar, porque los AR suponen un acuerdo entre víctima e imputado, que son las partes directamente afectadas por el delito, en tanto que la SCP supone un acuerdo entre el imputado y el Estado, representado por la figura del fiscal. La misma circunstancia de que en la SCP el imputado deba "negociar" con el Estado, representado por el Ministerio Público, justifica que la presencia del defensor sea un requisito de validez, y más aún, de legitimidad, de esta salida procesal. En cambio, en los acuerdos reparatorios, el acuerdo se produce entre las partes directamente afectadas, no siendo la presencia del defensor, ni de fiscal, un requisito de validez de la misma. ${ }^{32}$

Por su parte, Horwitz y López ${ }^{33}$ señalan que el fundamento de esta diferencia radica en que tratándose de los acuerdos reparatorios, la extinción de la responsabilidad penal se produce desde que se aprueba el acuerdo, en tanto que en la suspensión condicional del procedimiento ésta sólo se produce cuando ha transcurrido el plazo de la suspensión sin que ésta se hubiere revocado. Con la reforma incorporada por la Ley N 20.074 al Art. 242 CPP, éste fundamento ya no subsistiría, por cuanto es preciso que el acuerdo se haya cumplido o garantizado su cumplimiento para que proceda la extinción de la

\footnotetext{
${ }^{30}$ No obstante, algunos fiscales invocan estos antecedentes en la solicitud de medidas cautelares, con lo cual se relativiza, en la práctica, la protección al principio de presunción de inocencia que conlleva esta salida.

${ }^{31}$ La "informalidad" de los programas y sistemas de autocomposición de conflictos varía según la intensidad del contacto e interdependencia que éstos tengan con el sistema penal, de manera que no es lo mismo, por ejemplo, si un programa de mediación penal funciona en la Fiscalía, que si funciona en la comunidad.

${ }^{32}$ HORWITZ/LÓPEZ, Derecho Procesal Penal Chileno, cit. nota $\mathrm{n}^{\circ}$ 16, p. 574, plantean que si bien el juez debe citar a todos los intervinientes a la audiencia, incluyendo entre éstos al imputado, defensor y fiscal, la presencia del fiscal no es un requisito de validez de la misma, sin perjuicio de la imposición de sanciones disciplinarias en caso de su inasistencia.

${ }^{33}$ HORWITZ/LÓPEZ, Derecho Procesal Penal Chileno, cit. nota no 16, p. 574.
} 
DÍAZ, ALEJANDRA. "La experiencia de la mediación penal en Chile".

responsabilidad penal. En los acuerdos reparatorios al Estado le cabe una participación menor, constituyéndose en el garante de la legalidad y voluntariedad de los acuerdos, a través del requisito de aprobación de los acuerdos por parte del juez de garantía. Sin embargo, el Estado no ha renunciado por completo a su poder sobre el conflicto en cuestión, pues aún cuando se trate de delitos que el legislador autorizó para terminar mediante esta vía autocompositiva, el fiscal puede oponerse a su aprobación, o el juez negarla de oficio, si existe un "interés público prevalente" en la persecución penal.

La suspensión condicional del procedimiento procede en general respecto de delitos leves o de mediana gravedad, dado que la ley señala como límite de su procedencia que se trate de delitos que, en el evento de dictarse sentencia condenatoria, la pena que pudiere imponerse al imputado no excediere de tres años de privación de libertad. En la práctica, la SCP se dicta mayoritariamente para delitos contra la propiedad no violentos. Sin embargo, como el límite de tres años de privación de libertad se refiere a la pena concreta que pudiere imponerse al imputado en caso de ser condenado, la SCP se puede aplicar a delitos más graves, de concurrir circunstancias atenuantes de responsabiliadad penal u otras circunstancias del hecho o personales del imputado (por ejemplo, que se trate de un delito frustrado, o de un cómplice o encubridor). Además, debe tratarse de imputados que no hubieren sido condenados anteriormente por crimen o simple delito (sin embargo, podría tener condenas por faltas, que son las infracciones a la ley penal más leves del ordenamiento jurídico nacional). ${ }^{34}$

El 14 de marzo de 2008 se dictó la Ley $\mathrm{N}^{\circ} 20.253$ llamada de "Agenda Corta", que modificó diversas disposiciones del Código Penal, Código Procesal Penal y Ley Orgánica del Ministerio Público en materia de seguridad ciudadana, reformando, entre otros, al art. 237 del CPP, haciéndolo más restrictivo, por la vía de añadir, en su nueva letra c), un requisito adicional de procedencia de la suspensión condicional del procedimiento, cual es: "Si el imputado no tuviere vigente una suspensión condicional del procedimiento, al momento de verificarse los hechos del nuevo proceso". Asimismo, se añadió un nuevo inciso $6^{\circ}$ al mismo artículo, señalando:

"Tratándose de imputados por delitos de homicidio, secuestro, robo con violencia o intimidación en las personas o fuerza en las cosas, sustracción de menores, aborto, los contemplados en los artículos 361 a 366 bis, 367 y 367 bis del Código Penal y conducción en estado de ebriedad causando la muerte o lesiones graves o gravísimas, el fiscal deberá someter su decisión de solicitar la suspensión condicional del procedimiento al Fiscal Regional”.

Por su parte, el Oficio $N^{\circ} 404$ de 2003 del Fiscal Nacional instruyó a los fiscales de abstenerse de decretar la suspensión condicional del procedimiento tratándose de delitos sexuales, especialmente cuando la víctima es menor de edad o se trata del delito de violación. En general, el Oficio establece que excepcionalmente procede la SCP en delitos

\footnotetext{
${ }^{34}$ Las infracciones u ofensas penales en el sistema jurídico penal chileno se dividen, atendida su gravedad, en crímenes, simples delitos y faltas, según la pena asignada al delito (Art. 3 Código Penal).
} 
Polít. crim. Vol. 5, No 9 (Julio 2010), Art. 1, pp. 1-68.

[http://www.politicacriminal.cl/Vol_05/n_09/Vol5N9A1.pdf]

sexuales, cuando el único antecedente inculpatorio es la declaración de la víctima y ésta se encuentra de tal manera victimizada que es casi cierto que no declarará en el juicio, y siempre mediando autorización previa del Fiscal Regional. Este Oficio se dictó luego de la ocurrencia de algunos casos de connotación pública difundidos a través de la prensa nacional, en donde se acordaron suspensiones condicionales del procedimiento en ciertos delitos sexuales.

\subsubsection{El principio de oportunidad.}

Finalmente, una tercera oportunidad para incorporar la mediación penal en Chile como forma de "diversión", 35 es a través del principio de oportunidad. Este principio consiste en la facultad del fiscal de no iniciar la persecución penal, o abandonar la ya iniciada, cuando se tratare de un hecho que no comprometiere gravemente el interés público, y siempre que la pena mínima asignada al delito no exceda de presidio o reclusión menor en su grado mínimo (esto es, 540 días de privación de libertad), ni que se trate de un delito cometido por un funcionario público en el ejercicio de sus funciones (Art. $170 \mathrm{CPP}$ ). El fiscal debe emitir una decisión motivada, la que debe ser comunicada al juez de garantía, quien a su vez la notificará a los intervinientes, otorgando una oportunidad a éstos para reclamar de dicha decisión (que en definitiva permite a la víctima oponerse al ejercicio de la oportunidad por parte del fiscal). Dentro del plazo de 10 días de comunicada la decisión del fiscal, el juez podrá dejarla sin efecto, de oficio o a petición de parte, cuando el fiscal hubiere excedido sus atribuciones en cuanto a las hipótesis de procedencia de la misma. También la dejará sin efecto, cuando dentro del mismo plazo, la víctima manifestare de cualquier modo su interés en el inicio o la continuación de la persecución penal. La resolución del juez en cualquiera de estos casos obliga al fiscal. Transcurrido el plazo de 10 días para reclamar, o rechazada la reclamación, los intervinientes contarán con un plazo de 10 días para reclamar ante las autoridades del Ministerio Público. El Art. 170 CPP regula el procedimiento de reclamación en estos casos. El principio de oportunidad extingue la responsabilidad penal del imputado, pero no impide perseguir la responsabilidad civil derivada del hecho ilícito.

El principio de oportunidad, por tanto, puede resultar un mecanismo más simple para desarrollar la mediación penal, en términos de procedimiento, que los acuerdos reparatorios, en la medida que no se requiere de una audiencia judicial especial con la presencia de la víctima e imputado para aprobarlo, sino que basta la comunicación del fiscal al juez y, si la víctima no se opone y se cumplen con los requisitos de procedencia del principio de oportunidad, y transcurrido los plazos legales para formular la reclamación, se entenderá extinguida la responsabilidad penal. Sin embargo, el acuerdo reparatorio procede respecto de delitos para los cuales no es posible aplicar el principio de oportunidad por la entidad de la pena, como el robo en lugar no habitado, por lo que siempre sería necesario recurrir a este mecanismo, o a la suspensión condicional del procedimiento, tratándose de

\footnotetext{
${ }^{35}$ En el sentido de la palabra en inglés "diversion", que hace referencia, en términos generales, a la posibilidad de derivar tempranamente un caso fuera del proceso penal formal, para que sea resuelto por medios más informales o bien sea desestimado completamente, por su carácter de bagatela.
} 
DÍAZ, ALEJANDRA. “La experiencia de la mediación penal en Chile”.

esos delitos. Por otra parte, la ventaja del acuerdo reparatorio es que establece un control judicial a la legalidad de los acuerdos, así como a la voluntariedad de las partes. Además, no se debe desestimar el efecto simbólico que tiene para algunas personas el hecho de que sea el mismo juez quien aprueba el acuerdo. Se suele señalar que en la cultura chilena, las personas otorgan mayor validez a los acuerdos cuando son aprobados por una autoridad judicial, o a lo menos, cuando poseen un mecanismo eficiente para exigir su cumplimiento. Este aspecto se menciona más adelante, a propósito de un estudio sobre proyectos de mediación realizados en Chile.

\section{La Mediación Penal en Chile.}

Las instituciones procesales analizadas en los párrafos anteriores, esto es, las salidas alternativas y el principio de oportunidad, posibilitan o abren la puerta para incluir mecanismos de resolución alternativa de conflictos y de justicia restaurativa en ellas, tales como la mediación penal. Sin embargo, el desarrollo de la mediación penal para ofensores adultos es aún incipiente en Chile, no habiéndose implementado una política nacional tendiente a hacerla efectiva, como sí ha sucedido, por ejemplo, en el caso de la mediación familiar. ${ }^{36}$

No es posible analizar el desarrollo de la mediación penal en Chile, sin hacer referencia a distintos movimientos, tendencias, teorías e iniciativas que han tenido lugar en el país en las últimas décadas en el ámbito de la justicia penal y de la justicia en general. Se trata de: a) el movimiento por la resolución alternativa de conflictos (RAC), b) la incorporación de las necesidades e intereses de las víctimas en el proceso penal, y c) la recepción en Chile de la teoría de la justicia restaurativa. A ellos se hará referencia a continuación, para luego abordar el desarrollo específico de proyectos de mediación penal. En lo que respecta al movimiento RAC, se hará referencia a las diversas modalidades de mediación familiar, laboral, de salud, $y$ otras que, si bien no constituyen mediación penal, han permitido sensibilizar tanto a los actores de la justicia como a la opinión pública con estas formas alternativas de resolución de conflictos.

\footnotetext{
${ }^{36}$ La nueva Ley de Tribunales de Familia No 19.968 contempla a la mediación como proceso de resolución de conflictos alternativo al juicio. Se contempla también la figura del mediador, estableciéndose por ley los requisitos para ser mediador familiar en Chile. En un principio, la Ley $\mathrm{N}^{\mathrm{o}} 19.968$ estableció a la mediación como una alternativa al juicio, de carácter voluntario para las partes, debiendo primero interponerse la demanda civil para poder acceder a la mediación y debiendo las partes, además, pagar por el servicio del mediador. Sin embargo, la mediación fue poco utilizada en la práctica, pues las partes preferían tramitar su causa ante el juez, para lo cual no necesitaban comparecer a través de abogado habilitado, pudiendo hacerlo personalmente. El poco uso de la mediación motivó un cambio en la ley, siendo ésta reformada por Ley $\mathrm{N}^{\circ} 20.286$ de septiembre de 2008, la cual transformó la mediación en obligatoria para las materias de derecho de alimentos, cuidado personal y visitas, además de convertirla en gratuita para estos casos (salvo que la persona disponga de recursos para costearla total o parcialmente), y de exigir la obligatoriedad de comparecer ante el tribunal de familia mediante abogado habilitado, salvo excepciones. Obviamente, sólo es obligatorio acudir al proceso de mediación, más el acuerdo sigue siendo voluntario. Con estas reformas se pretende aumentar significativamente el uso de la mediación en materias de familia en Chile. El Reglamento detalla los principios de la mediación familiar, los cuales son, en muchos aspectos, similares a los que se señalan para la mediación penal en diversos instrumentos de organizaciones internacionales, de Estados y de organismos internacionales.
} 
Polit. crim. Vol. 5, No 9 (Julio 2010), Art. 1, pp. 1-68.

[http://www.politicacriminal.cl/Vol_05/n_09/Vol5N9A1.pdf]

\subsection{El movimiento RAC o ADR.}

El movimiento de resolución alternativa de conflictos, de resolución alternativa de disputas (RAD, o ADR - según su sigla en inglés-), o también llamado de sistemas alternos de resolución de conflictos (SARC), llega a Chile a comienzos de la década de los 90, de la mano de una serie de reformas a la administración de justicia destinadas a su modernización. Se caracterizan por ser procedimientos voluntarios y no adversariales, que permiten resolver disputas de manera alternativa al juicio legal, formal. De acuerdo a Cox y Salgado, "aunque la legislación chilena contempla diversas modalidades de aplicación tanto judicial como extrajudicial, estos mecanismos no constituyen la expresión definida de un

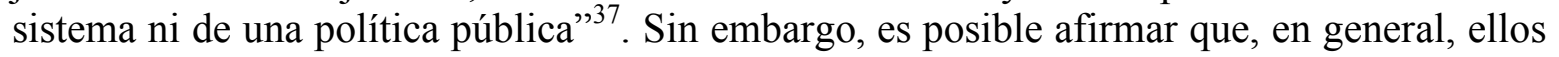
han estado vinculados en Chile con las siguientes finalidades y/o ideologías:

- Aumentar el acceso a la justicia de sectores más pobres que, por los altos costos de la litigación, no pueden acceder a ésta o sólo lo hacen de manera insuficiente o de mala calidad. Se vincula ese objetivo generalmente a una crítica a los sistemas judiciales formales (lentos, engorrosos, distantes) así como al uso extensivo de la ley como sistema para dirimir las disputas (por ser clasista, abstracta y por ende definir los conflictos de manera muy distinta a cómo lo viven los directamente involucrados en ellos, y que logra una igualdad formal más no sustancial).

- Entregar soluciones de mejor calidad a las partes, que sean de tipo colaborativo, en donde todos ganan, a diferencia de la justicia legal, en donde casi siempre hay un perdedor y un ganador. Este objetivo es especialmente perseguido tratándose de conflictos de naturaleza sistémica y/o en donde las partes continuarán relacionándose, como en los conflictos de familia y laborales.

- Democratizar la sociedad por la vía de difundir, promover y enseñar una cultura del diálogo, que propenda a una mayor paz social.

- Descongestionar la carga de los tribunales, permitiendo que éstos se aboquen a causas más complejas, y así poder dar respuestas de mejor calidad. Se presupone en esta lógica que los RAC serían más baratos que la judicialización. Se derivarían a mecanismos informales los asuntos menos graves, o de menor entidad, y/o aquellos en los que hay un interés marcadamente privado, y en donde el interés público en su resolución es más lejano o indirecto (como por ejemplo, ciertas disputas comerciales y civiles) ${ }^{38}$

\footnotetext{
${ }^{37}$ COX, S.; SALGADO, C., "Resolución alternativa de conflictos en América: Chile", Resolución Alternativa de Conflictos, Revista $\mathrm{N}^{\circ} 2$ (2001), en: http://www.cejamericas.org/sistemas-judiciales

38 VARGAS, J.E., "Problemas de los sistemas alternos de resolución de conflictos como alternativa de política pública en el sector judicial", Resolución Alternativa de Conflictos, No2 (2001), en: http://www.cejamericas.org/sistemas-judiciales
} 
DÍAZ, ALEJANDRA. "La experiencia de la mediación penal en Chile".

- Propuestas comunitarias, que ven en las RAC una vía para empoderar a las comunidades, lo que a su vez tendría beneficios en distintos ámbitos en términos de ampliar los espacios de participación democrática.

La RAC en Chile surge principalmente en base a iniciativas del Estado, existiendo también un significativo apoyo de parte de organismos internacionales, tales como la OEA, para su promoción y financiamiento, el cual se recibe de forma coetánea a la colaboración internacional prestada para realizar reformas a la justicia en términos más amplios. ${ }^{39}$ También, la RAC surge en Chile desde la sociedad civil, especialmente a través de organizaciones no gubernamentales (ONGs) y Universidades, aunque generalmente con apoyo estatal.

Los métodos de RAC más implementados y conocidos en Chile son:

\subsubsection{La Conciliación judicial y extrajudicial.}

Es un proceso a través del cual un tercero neutral intenta avenir a las partes en conflicto, proponiéndoles bases de arreglo para ello. En la conciliación judicial, el que propone bases de arreglo es el juez. En la extrajudicial, el tercero puede estar representado por un organismo administrativo, como la Inspección del Trabajo. ${ }^{40}$ Lo que marca la diferencia con la mediación es la forma de intervención del tercero. En la conciliación, el tercero opina y propone fórmulas de acuerdo. Muchas veces la opinión del tercero que interviene lleva a las partes a adoptar la solución propuesta y, en muchos casos, puede derivar en una falta de cumplimiento en los acuerdos. Por esto se suele decir, también, que "el juez concilia, no media". La conciliación judicial es más directiva que la conciliación extrajudicial y que la mediación, al estar radicada en el juez. La Ley No 19.333 de 1994 sobre Conciliación Judicial, la estableció por primera vez con carácter obligatoria para todos los procesos civiles, de menores y del trabajo. ${ }^{41} \mathrm{La}$ conciliación laboral ha representado un alto porcentaje de formas de término para este tipo de causas (alrededor de un $75 \%) .{ }^{42}$ Se ha contemplado este mecanismo expresamente en diversas leyes en Chile, tales como la primera ley de violencia-intrafamiliar $\mathrm{N}^{\circ} 19.325$, de materias de familia, derechos de los consumidores, y asuntos indígenas. Con anterioridad a la Reforma Procesal Penal, la reparación podía poner término al proceso penal en algunos casos, como por ejemplo, en el delito de giro doloso de cheques y, en los delitos de acción penal privada, en donde existía la fórmula del "avenimiento" para poner término anticipado al juicio.

\footnotetext{
${ }^{39}$ PARKER, L., "El uso de prácticas restauradoras en América Latina", Revista CREA, №4 (2003), pp. 217 242.

${ }^{40}$ ULLOA, M., "Los sistemas alternativos de resolución de conflictos", Ponencia presentada en el Colegio de Abogados de Concepción, Septiembre de 1998.

${ }^{41}$ Posteriormente, en el ámbito de menores y laboral, estas materias pasan a ser reguladas, respectivamente, en la Ley de Tribunales de Familia $\mathrm{N}^{\circ} 19.968$ y en el Código del Trabajo modificado por diversas leyes que establecen una nueva justicia laboral (Leyes No20.022, No 20.023, No20.252 y N²0.087).

${ }^{42} \mathrm{COX} / \mathrm{SALGADO}$, "Resolución alternativa de conflictos", cit. nota ${ }^{\circ} 37$.
} 
Polít. crim. Vol. 5, No 9 (Julio 2010), Art. 1, pp. 1-68.

[http://www.politicacriminal.cl/Vol_05/n_09/Vol5N9A1.pdf]

Asimismo, la reparación podía (y aún puede) tener consecuencias en la pena, por ejemplo, como atenuante de responsabilidad penal. ${ }^{43}$

\subsubsection{El arbitraje.}

Es un mecanismo alternativo de resolución de conflictos en el que las partes delegan la decisión del asunto en un tercero neutral, denominado árbitro. El arbitraje se aplica ampliamente en materias comerciales, civiles y laborales. Existen los Centros de Arbitraje de las Cámaras de Comercio, en distintas regiones del país.

\subsubsection{La negociación.}

Consiste en un proceso de mutua comunicación encaminado a lograr un acuerdo con otros cuando hay algunos intereses compartidos y otros opuestos. Los negociadores tienen una participación híbrida en cuanto a su imparcialidad, ya que representan a una de las partes, o bien, sin que las representen jurídicamente, trabajan para una de ellas, pero en todo caso, también trabajan para que las dos lleguen a un acuerdo. En Chile, la negociación se asimila al contrato de transacción en el ámbito civil (Art. 2446 y ss. del Código Civil) y en el ámbito laboral (Art. 386 y ss. del Código del Trabajo). Como se verá más adelante, también es una herramienta que se usa comúnmente en el ámbito penal entre fiscales y defensores, y abogados querellantes cuando los hay, en el marco de las salidas alternativas y el procedimiento abreviado.

\subsubsection{La mediación.}

En Chile, como se señaló, la mediación se ha desarrollado fundamentalmente en los ámbitos de familia, y laboral y, en menor medida, vecinal, comunitario y penal. También es un mecanismo contemplado en la Ley Indígena $\mathrm{N}^{\circ}$ 19.253. Si bien la norma del Art. 55 de dicha ley habla de "conciliación" para los juicios sobre tierras en los que se encuentre involucrado algún indígena, en la práctica, lo que se ha desarrollado es un proceso de mediación. ${ }^{44}$

La mediación ha sido entendida en Chile, en sus orígenes y en términos generales, como parte de los sistemas de resolución alternativa de conflictos, adoptándose las definiciones y modelos que sobre este mecanismo se han producido en el ámbito comparado, especialmente en Estados Unidos y Canadá, siendo especialmente influyentes en el ámbito práctico y teórico el modelo tradicional lineal de Harvard, el modelo transformativo de Bush y Folger, y el Modelo Circular Narrativo de Sara Cobb, entre otros; en Argentina, siendo particularmente influyentes las autoras Marinés Suárez, Elena Highton y Gladys Álvarez, y en España, la cual ha sido especialmente influyente en sus modelos y

\footnotetext{
${ }^{43}$ CARNEVALI, R., "Las políticas de orientación a la víctima examinadas a la luz del Derecho Penal", Revista de Derecho de la Pontificia Universidad Católica de Valparaíso, XXVI, Semestre I (2005), pp. $27-$ 39.

${ }^{44}$ LÓPEZ, J., "Formas Alternativas de Resolución de Conflictos en la Ley Indígena 19.253", Revista CREA, №2 (2002), p. 79.
} 
DÍAZ, ALEJANDRA. "La experiencia de la mediación penal en Chile".

experiencias de mediación penal, tales como el modelo de mediación penal de Catalunya, así como los autores Gema Varona, que conecta a la mediación con los principios y teorías del derecho penal y con la teoría y movimiento de justicia restaurativa, Jaume Funes, que trata la mediación penal en el ámbito de la justicia juvenil, y José Dapena, quien ha sido mediador y coordinador del Centro de Mediación Penal para jóvenes infractores de Catalunya, entre otros.

La Ley N 19.968 sobre Tribunales de Familia define a la mediación en su Art. 103 como: "aquel sistema de resolución de conflictos en el que un tercero imparcial, sin poder decisorio, llamado mediador, ayuda a las partes a buscar por sí mismas una solución al conflicto y sus efectos, mediante acuerdos". Esta definición posee, sin embargo, algunas diferencias con los elementos de la mediación penal, si se compara, por ejemplo, con la proporcionada por Gema Varona. ${ }^{45}$ La definición de Varona enfatiza elementos propios de la justicia y del conflicto penal que lo diferencian de los del ámbito de familia, civiles o laborales, por lo que permite ilustrar las diferencias a que apunta la mediación en general y la mediación penal, diferencias que no siempre han sido claramente comprendidas en Chile. Uno de los ámbitos en donde esto ha tenido influencia, es en que los proyectos que han realizado mediación penal en Chile, han tendido a plantear el desarrollo de varias reuniones de mediación entre víctima y ofensor, como sucede generalmente en la metodología de la mediación familiar. Esto no es necesariamente así en los programas comparados, como en el caso de los VORP, en donde el acuerdo se concluye por lo general en una sesión de mediación, de 1 a 2 horas máximo de duración. En estos programas VORP, la mayor frecuencia de sesiones se dará muchas veces en la fase de pre-mediación, en donde hay reuniones individuales con cada parte. Optar por una u otra metodología tiene relevancia considerando que los tiempos de duración del proceso pueden ser un aspecto muy sensible para que las instituciones de justicia penal (fiscalía o defensoría) estén dispuestas a derivar casos a mediación.

Se analizan a continuación algunos proyectos o programas destacados en mediación, los cuales han tenido lugar principalmente en los ámbitos civil y de familia. Se distingue entre aquéllos proyectos que surgen como una iniciativa estatal, y por tanto, ilustrativos de un desarrollo de la mediación "de arriba hacia abajo", de aquellos que surgen desde la sociedad civil, y por tanto, ilustrativos de un desarrollo "de abajo hacia arriba".

\section{a) Proyectos de mediación que surgen desde el Estado.}

Estos proyectos se enmarcan en el proceso de modernización de la justicia en Chile, y la promoción del acceso a la justicia a través de la resolución alternativa de conflictos, en los ámbitos de familia, civil, laboral, vecinal, y en menor medida, penal. Son una de las bases del desarrollo de la mediación penal posterior, pues permiten acumular experiencia en mediación, e incorporar este concepto por primera vez en la cultura jurídica chilena, la cual ha sido caracterizada como formalista y proclive a la judicialización de los conflictos, aspecto que se aborda más adelante (Sección V). Asimismo, estos primeros proyectos han

\footnotetext{
${ }^{45}$ Ver Supra, par. II.
} 
Polít. crim. Vol. 5, No 9 (Julio 2010), Art. 1, pp. 1-68.

[http://www.politicacriminal.cl/Vol_05/n_09/Vol5N9A1.pdf]

capacitado a numerosos profesionales en técnicas de mediación, principalmente abogados, asistentes sociales y sicólogos, formando una red de mediadores calificados, algunos de los cuales posteriormente han participado en iniciativas relacionadas con la mediación penal. Asimismo, forman una base interesante de profesionales mediadores calificados a la cual recurrir a futuro, en el evento de que se expanda la mediación penal en Chile. Finalmente, han aportado datos, estudios, y reflexiones acerca del proceso de mediación, su impacto en las partes, el perfil de los participantes, los tiempos que toma el proceso, y las dificultades de llevar a cabo la mediación, de arribar a acuerdos y de que éstos se cumplan, todo lo cual, sin duda, constituye y ha constituido, un insumo importante para el desarrollo de la mediación penal.

- Centro de Mediación de Santiago, de la Corporación de Asistencia Judicial.

Las Corporaciones de Asistencia Judicial (en adelante, CAJ) son entidades públicas, que tienen por objeto proporcionar asistencia jurídica gratuita a las personas de escasos recursos, que no pueden procurárselos por sí mismas, en los diversos ámbitos del derecho. Las CAJ también prestan sus servicios legales a través de estudiantes egresados de las Escuelas de Derecho, que deben hacer su práctica profesional en dichas instituciones como requisito para titularse. ${ }^{46}$ Las Corporaciones están divididas en dos secciones: la sección jurídica y la sección social, la primera compuesta por abogados y la segunda, por asistentes sociales. Desde principios de la década de los 90, los profesionales de la sección social comenzaron a introducir prácticas de conciliación y mediación como una forma distinta de dar respuesta a los conflictos de las personas que llegaban a solicitar los servicios de la Corporación, dándose cuenta, al poco andar, que esta aproximación tenía muy buenos resultados. ${ }^{47}$ Así, comienza a gestarse la idea de institucionalizar estas prácticas, y nace en el año 1996 el Centro de Mediación de Santiago de la CAJ, con el apoyo del Ministerio de Justicia el cual lo monitoreó y evaluó como proyecto piloto. La evaluación positiva de este programa motivó a que la CAJ abriera otro centro en la zona nor-poniente de Santiago, y suscribiera un convenio con la Ilustre Municipalidad de Las Condes para implementar un programa de mediación vecinal y familiar vinculado a sus centros comunitarios. ${ }^{48}$ Paralelamente, se creó un Centro Piloto de Resolución de Conflictos en la comuna de Huechuraba, mediante un convenio entre la municipalidad y la CAJ, y entre los años 1999 y 2000, se implementó el Centro de Mediación de Independencia. ${ }^{49}$ El Centro de Mediación de Santiago se integró por una abogada coordinadora, dos asistentes sociales mediadoras, un psicólogo mediador, una técnico social encargada de la recepción de las personas, una

\footnotetext{
${ }^{46} \mathrm{Si}$ bien con la reforma procesal penal ya no proporcionan abogado defensor a los imputados de escasos recursos, servicio que es actualmente prestado por la Defensoría Penal Pública, sí pueden representar a las víctimas para actuar como querellantes en las causas criminales.

${ }^{47}$ CORPORACIÓN DE ASISTENCIA JUDICIAL R.M. Resolución Alternativa de Conflictos: Una opción democrática de acceso a la justicia. Una forma de intervención humanizante en la Asistencia Jurídica Gratuita, Santiago: Editorial Jurídica de Chile, 2003.

${ }^{48}$ BURGOS, J., "Centro de mediación de Santiago 'experiencia y desafíos futuros", Revista CREA, №3 (2002), pp. 185-90.

${ }^{49}$ CORPORACIÓN DE ASISTENCIA JUDICIAL R.M., Resolución Alternativa de Conflictos, cit. nota no 47.
} 
DÍAZ, ALEJANDRA. "La experiencia de la mediación penal en Chile".

secretaria y un postulante de derecho. Atendió variadas materias, aunque la mayor parte de éstas eran familiares, civiles y laborales, una menor cantidad de causas vecinales, y una pequeña cantidad de causas penales, siendo entre éstas, las más frecuentes, los cuasidelitos y negligencias médicas. El centro ha sido muy activo en la difusión de la mediación, y actividades de extensión, capacitaciones en mediación, las cuales han incluido la realización de pasantías para los alumnos.

Las cifras de la CAJ sobre resolución alternativa de conflictos llevada a cabo en la Región Metropolitana, la VI, VII, y XII Regiones, entre enero y agosto de 2002, muestran que se atendió por esta vía a un total de 10.002 casos, que representa el 13,6\% del total de tipos de atención prestadas por la $\mathrm{CAJ}$ en dichas regiones, siendo los restantes tipos de atención la judicial y extrajudicial (entre estas últimas, la información de derechos). Del total de 10.002 casos, un $0,3 \%$ correspondió a casos penales, consistiendo mayoritariamente en cuasidelitos y negligencias médicas.

Respecto a los resultados de las intervenciones en RAC, el 52\% se terminaron en acuerdo, el $40 \%$ no hubo acuerdo, y el $8 \%$ se encontraban en proceso al momento de elaborar las estadísticas. $^{50}$

Algunas de las características centrales del modelo de RAC utilizado en el Centro son: ${ }^{51}$

- El tercero facilitador puede ser un abogado o asistente social, y su rol es equiparar a las partes y asesorarlas en la clarificación e identificación de los factores intervinientes en el conflicto, el marco legal vigente y las alternativas de solución.

- La utilización en el desarrollo de la sesiones de elementos técnicos tales como: observación (participante y no participante), entrevista (estructurada, semi-estructurada, en profundidad, etc.) sociogramas, dinámicas participativas, negociación, mediación y/o conciliación.

- Si las partes logran acuerdos, éstos se formalizan en un documento denominado "transacción", solicitándose posteriormente su aprobación judicial.

- Se valora tanto el proceso en sí, como los resultados consistentes en la consecución de un acuerdo.

- Se considera a los usuarios como "persona/sujeto", en donde la persona (reclamante y reclamado) y sus derechos tienen un lugar central, abordándose ello desde la perspectiva kantiana, del hombre no como cosa, que pueda usarse como medio, sino como fin en sí mismo. La idea es ir generando espacios de reconocimiento, primero de

\footnotetext{
${ }^{50}$ CORPORACIÓN DE ASISTENCIA JUDICIAL R.M., Resolución Alternativa de Conflictos, cit. nota ${ }^{\circ}$ 47, pp. 41-5.

${ }^{51}$ CORPORACIÓN DE ASISTENCIA JUDICIAL R.M., Resolución Alternativa de Conflictos, cit. nota ${ }^{\circ}$ 47, pp. 47-8.
} 
Polít. crim. Vol. 5, No 9 (Julio 2010), Art. 1, pp. 1-68.

[http://www.politicacriminal.cl/Vol_05/n_09/Vol5N9A1.pdf]

sí mismos, y luego hacia el otro, promoviendo un proceso de revinculación y sensibilización, basándose en el respeto de los derechos en disputa.

\section{- Programa de Resolución de Conflictos Anexo a Tribunales}

Este programa fue implementado en el año 1997 por el Ministerio de Justicia, en las ciudades de Valparaíso y Santiago, como un proyecto piloto destinado a conocer, testear y socializar la aplicación de las experiencias de mediación comparadas en el sistema de justicia chileno, vinculado a conflictos de familia. Nace estrechamente relacionado con el proyecto de ley que crea los tribunales de familia, el cual contemplaba la incorporación de la mediación como un mecanismo importante de resolución de conflictos familiares. El proyecto transformado finalmente en ley en el 2004, incorporó por primera vez en Chile a la mediación a nivel legislativo. El programa piloto anexo a tribunales permitió testear esta experiencia previo a la entrada en vigencia de la ley de tribunales de familia y a la implementación de un sistema de mediación a nivel nacional, a la vez que posibilitó sensibilizar a la población en el uso de estas prácticas más colaborativas.

El Programa fue integrado por un cuerpo de mediadores compuesto por 14 profesionales: 6 abogados, 6 asistentes sociales y 2 psicólogos. Los casos eran derivados, en una primera etapa, por los juzgados de menores, ${ }^{52}$ y luego se amplió la fuente de derivación recibiéndose casos directamente desde la comunidad y/o público en general, gracias tanto a la implementación de una campaña de difusión del programa, como a la recomendación del programa a familiares y conocidos, por parte de quienes habían participado en el mismo.

El modelo teórico e ideológico aplicado por el Programa privilegió tanto la consecución de acuerdos, como los aspectos relacionales entre las partes, tanto por los beneficios inmateriales que se obtienen del proceso de diálogo entre las partes propiciado por la mediación, como por la creencia de que una buena comunicación es esencial para lograr un buen acuerdo. Así, no adscribieron a un modelo teórico único - de negociación en base a principios, transformativo o circular narrativo- sino que se encaminaron hacia la búsqueda de un modelo propio, de carácter más bien ecléctico, que combinó elementos distintivos de uno y otro: del modelo circular narrativo de Sara Cobb, tomaron aspectos relativos a la comunicación e interacción entre los participantes, del modelo transformativo de Bush y Folger, recogieron la valorización del proceso como espacio de validación $\mathrm{y}$ reconocimiento de las necesidades de cada uno, y del modelo de negociación de Harvard, tomaron el acento puesto en el logro de acuerdos. ${ }^{53}$

\footnotetext{
${ }^{52}$ Con anterioridad a la ley que creó los tribunales de familia, a los juzgados de menores correspondía ver las causas de familia.

${ }^{53}$ VARGAS, Macarena, "Mediación familiar en Chile. La experiencia del Programa de Resolución de Conflictos anexo a Tribunales", Resolución Alternativa de Conflictos, № (2001), p. 4, en: http://www.cejamericas.org/sistemasjudiciales/tema central.php? revista $=2 \&$ idioma $=$ espanol $\&$ secc $=230 \&$ TemaNiv $2=230$ [visitado en marzo de 2009]
} 
DÍAZ, ALEJANDRA. "La experiencia de la mediación penal en Chile".

La evaluación de la experiencia mostró los siguientes resultados: ${ }^{54}$

Desde el año 1997 a 2000, ingresaron un total de 1.044 casos. Del total de ingresos, 695 casos $(66,5 \%)$ fueron efectivamente mediados. De los casos mediados, se alcanzó acuerdo en el $52,3 \%$ de ellos.

En cuanto a los resultados cualitativos, se realizó un estudio de percepción de usuarios que reveló lo siguiente:

De una muestra de 100 casos seleccionada al azar, se detectó la siguiente percepción de los entrevistados (sólo se pudo entrevistar a los demandantes, ${ }^{55}$ que en su mayoría eran mujeres jóvenes, de menos de 35 años, que desempeñaban labores remuneradas fuera del hogar):

La gran mayoría de los demandantes manifestaron que al momento de concurrir al tribunal para hacer su demanda, no tenía conocimiento acerca de la mediación, y también una gran mayoría señaló que al proponérsele la mediación, se le explicó en qué consistía. La mayoría de los demandantes $(78 \%)$ declara haber percibido la propuesta de mediación como un consejo susceptible de seguir o no. Esta mayoría sostiene, además, haber tenido claro su derecho a aceptar la mediación o a seguir adelante con el trámite judicial. Aquellos entrevistados que dicen haber tenido claro su derecho a rechazar la propuesta de mediación y el haber percibido en ella sólo un consejo, expresan con la mayor frecuencia que sus motivos para preferir la mediación fueron el deseo de evitar la agudización del conflicto con la otra parte (44\%) o el de evitar lo engorroso del trámite judicial (29\%).

Una amplia mayoría de los entrevistados consideró que el mediador facilitó su comunicación con la otra persona, que le inspiró confianza con respecto a su discreción, y que fue imparcial y no trató de imponer sus ideas.

De la muestra de 100 casos, el 66\% percibió que la mediación finalizó con un acuerdo. De éstos, el $77 \%$ percibió que éste fue satisfactorio. Un dato interesante es que el cruce de edades entre los que llegaron a acuerdo y los que no, constató que la proporción de acuerdos fue mayor entre los menores de 30 años, es decir, entre los más jóvenes.

Al total de entrevistados que dicen haber llegado a acuerdos, se les consultó sobre el cumplimiento de los mismos, siendo el porcentaje de cumplimiento de un $42 \%$. Casi la totalidad de los entrevistados (93\%) que llegaron a acuerdo, estima que la mediación fue un aporte positivo, señalándose entre los motivos que la mediación ayudó a mejorar la comunicación con el otro. Por su parte, la totalidad de los entrevistados $(100 \%)$ que llegaron a acuerdos -se hayan o no cumplido- recomienda la mediación como instancia de solución de problemas.

\footnotetext{
${ }^{54}$ La sistematización de la experiencia y detalle de datos estadísticos se puede consultar en: VARGAS, "Mediación familiar en Chile", cit. nota $\mathrm{n}^{\circ} 53$.

${ }^{55}$ Que es quien demanda o pretende interponer una demanda o acción judicial en contra de la otra parte, que en casos de familia será por lo común el otro cónyuge o progenitor de hijo/s en común.
} 
Polít. crim. Vol. 5, No 9 (Julio 2010), Art. 1, pp. 1-68.

[http://www.politicacriminal.cl/Vol_05/n_09/Vol5N9A1.pdf]

Finalmente, del 34\% que declaró no haber llegado a acuerdo, la mayoría estimó de todas formas que su experiencia de mediación fue positiva y el $82 \%$ la recomendaría a familiares o conocidos con problemas semejantes a los suyos.

Estos resultados validan la metodología abordada por el programa en cuanto a privilegiar tanto el logro de acuerdos como los aspectos relacionales entre las partes.

Se entrevistó también a 12 jueces de menores de Santiago y Valparaíso adscritos al programa. Es interesante destacar el siguiente párrafo del estudio en el que se da cuenta de algunas de las opiniones y percepciones de los jueces entrevistados:

"Si bien no hay consenso, la mayoría de los jueces entrevistados -deriven o no casos a los centros de mediación y hagan o no reparos jurídicos a ella- piensan que ésta no se aviene a nuestro contexto cultural. Señalan que en general, y sobre todo en los sectores populares, anima una cultura exacerbadamente autoritaria. Prima la inseguridad en sí mismo y la desconfianza en el otro. A juicio de los entrevistados, ambos sentimientos se conjugan con la convicción de que sólo una figura o ámbito de autoridad -el juez, el tribunal- son capaces de hacer "entrar en vereda a las partes". Una vez que estalla el conflicto, el manejo de la agresividad es tal, que se piensa que sólo el golpe de autoridad de un tercero es capaz de imponer orden.

Opinan que la nuestra no es una cultura que elabore las discrepancias vía la discusión, la negociación y la articulación de acuerdos.... Y cuando se trata de conflictos entre la pareja, el machismo viene a potenciar el autoritarismo imperante, percibiéndose hombres y mujeres atropellados en la dignidad de su sexo. "Librados a sí mismos no van a llegar nunca a un arreglo. Cada cual defiende tozudamente su posición, luego alguien tiene que proponer soluciones". (magistrado).

Otro juez agrega: "A la hora de la verdad sale el macho que, cuando hay crisis, usa al niño para castigar a la mujer. La paternidad en Chile es algo débil, se da según como ande la relación de pareja. Si el hombre anda mal con la mujer, hay indiferencia con el niño"”."

En cierto sentido, estas opiniones ilustran un aspecto relevante de la cultura jurídica en Chile y específicamente, la judicial, así como la posición o lugar que cabe a la mediación en ella. Este aspecto será profundizado más adelante ${ }^{56}$ al explorar las razones del particular desarrollo que ha tenido la mediación penal en Chile.

- Programa de Asistencia Jurídica (PAJ)

Este programa se implementa en el año 1993 por el Ministerio de Justicia en la Región Metropolitana y del Bío-Bío, extendiéndose posteriormente a otras regiones del país. La finalidad del Programa era permitir el acceso a la justicia de las personas de escasos de recursos que habitaran en las comunas pobres del país en donde el PAJ funcionase. Tenía 4 líneas o ejes de acción: 1) Información y Orientación Social individual, 2) Resolución

\footnotetext{
${ }^{56}$ Ver Sec. V.
} 
DÍAZ, ALEJANDRA. "La experiencia de la mediación penal en Chile".

extrajudicial de conflictos, 3) Patrocinio judicial (tramitación en tribunales) en los casos en que no se llegase a acuerdo, y 4) Trabajo comunitario para la difusión de derechos y capacitación en materias jurídico-sociales, que involucraba coordinación con otras instituciones públicas y privadas para enfrentar con anticipación los problemas más acuciantes y recurrentes de la comuna. ${ }^{57}$ En la línea de Resolución Alternativa de Conflictos, las materias más comúnmente recibidas eran temas de familia, y entre éstos, de pensión de alimentos. Al igual que en el caso del programa Anexo a Tribunales, los casos se recibían principalmente de mujeres que querían demandar a sus parejas o ex parejas por alimentos. El programa funcionaba en base a consultorios fijos y móviles, en los cuales trabajaban equipos conformados por un abogado y una asistente social (ambos jornada completa), una secretaria o chofer, y en varios consultorios existían, además, abogados auxiliares contratados por media jornada y alumnos de la carrera de Derecho que realizaban su práctica profesional. Los mecanismos de resolución alternativa de conflictos más usados por el PAJ eran la conciliación y el arbitraje.

El tipo de conciliación usada consistía en que un tercero semi-imparcial (profesional del PAJ) ${ }^{58}$ estaba presente en la discusión con el propósito de facilitar la búsqueda de una solución al conflicto. Si bien no asumía una postura pasiva, trataba de motivar a las partes a centrarse en los puntos comunes más que en las diferencias que pudieran tener. Las partes iban proponiendo alternativas en función de las áreas que el tercero podía proponerles, sobre todo cuando las partes no eran capaces de identificar los aspectos en conflicto, cuestión que ocurría básicamente cuando una de las partes había sido víctima de una situación de violencia física, psíquica o económica, con lo cual no existía igualdad de poderes para negociar. ${ }^{59}$ El arbitraje utilizado tenía características más similares a la conciliación extrajudicial que al arbitraje propiamente tal. El procedimiento de recepción de casos consistía en que una de las partes acudía al consultorio jurídico a solicitar alguna de las asesorías socio-jurídicas que éste prestaba. Los profesionales del PAJ procedían a citar a ambas partes a un comparendo extrajudicial en el cual, luego de analizar la situación conflictiva, se ofrecía la posibilidad de buscar una alternativa de solución mediante algunas de las técnicas de RAC previamente descritas. Si se llegaba a acuerdo, se redactaba un escrito de avenimiento o acuerdo extrajudicial, al cual se le podía o no dar carácter judicial mediante su aprobación por el juez. ${ }^{60}$

\footnotetext{
${ }^{57}$ ABARCA, A., "Resolución Alternativa de Conflictos en el área familiar", Revista Crea, $\mathrm{N}^{\circ} 1$ (2000), pp. 150-61.

${ }^{58}$ La circunstancia de que el procedimiento se iniciase a instancias de una de las partes, generalmente la demandante, con perfil de ser mujer, dueña de casa, con hijos y escasos recursos, que demandaba alimentos del marido o pareja, y que, si la causa no llegaba a acuerdo, el PAJ asumía la representación judicial de la demandante en tribunales, los motivaba a caracterizar al conciliador como "semi-imparcial".

${ }^{59}$ ABARCA, "Resolución Alternativa de Conflictos", cit. nota n 57, p. 153.

${ }^{60}$ Es interesante destacar que en una investigación llevada a cabo respecto del Centro de Mediación de Santiago de la CAJ, se detectó que las personas consideraron que la mediación, en cuanto al cumplimiento de los acuerdos, sería más efectiva si dichos arreglos estuviesen sometidos a la ratificación de un ministro de fe (juez, mediador, etc.) con poder de hacerlo cumplir, en PURCELL, C.; ARRUÉ, A.P.; MUÑOZ, C.G., "Investigación exploratoria acerca del proceso y resultados de la aplicación de la mediación como técnica alternativa de resolución de conflictos en el ámbito judicial”, Revista CREA, №2 (2001), pp. 204-212
} 
Polít. crim. Vol. 5, No 9 (Julio 2010), Art. 1, pp. 1-68.

[http://www.politicacriminal.cl/Vol_05/n_09/Vol5N9A1.pdf]

Finalmente, una característica especial de este programa es que estaba orientado tanto a la prevención de los conflictos, a través de su trabajo social y comunitario, como a la solución de los mismos, una vez que el conflicto se había producido y no había podido ser resuelto autónomamente por los involucrados. En el ámbito de la solución de los conflictos, destaca la aproximación del programa de representar a la parte demandante cuando no ha sido posible el acuerdo. Esto puede ser útil en términos de otorgar poder de negociación a la parte demandante que, dado el perfil común de éstas, suele estar en una situación de mayor vulnerabilidad o de menor poder.

Además de estos tres programas destacados en el movimiento de RAC en Chile, tanto por su calidad de pioneros, su influencia en el desarrollo de otros proyectos, como por la magnitud de los casos tramitados, cabe mencionar distintos proyectos impulsados desde el Estado en el ámbito de las RAC, especialmente: el proyecto Mece Media del Ministerio de Educación para la formación de mediadores escolares juveniles; el programa Cultura del Diálogo del Ministerio del Trabajo para formar "mediadores-comparendistas" para actuar en el primer comparendo de conciliación y en la negociación entre sindicatos y empresas; el amplio campo de la resolución de conflictos contemplada en la ley indígena, ${ }^{61}$ en donde cabe destacar el trabajo de la Oficina de Mediación de la CONADI (Corporación Nacional de Desarrollo Indígena) en Temuco, entre otros.

\section{b) Proyectos de mediación que surgen desde la sociedad civil.}

- Centro CREA de la Escuela de Derecho de la Universidad Católica de Temuco

El Centro CREA (Centro de Resolución Alternativa de Conflictos) nace el año 1998-1999 como una iniciativa desde el mundo universitario, con apoyo del Estado a través del Ministerio de Educación, para promover el acceso adecuado a la justicia de la población, por la vía de fomentar el uso de medios alternativos de resolución de conflictos, siendo el primer Centro de esta naturaleza en Chile en constituirse al interior de una Universidad. Luego de los primeros años de co-financiamiento entre la Universidad y el Ministerio, el Centro se independiza, quedando como un Centro perteneciente a la Escuela de Derecho. Este Centro comenzó haciendo mediación en el ámbito familiar y luego se extendió, aunque tímidamente, a la mediación de casos penales.

Otros objetivos perseguidos por el Centro, fueron: ${ }^{62}$

- Contribuir a mejorar la percepción sobre la justicia entre los sectores pobres del país, quienes, según diversos estudios de la época, la consideraban discriminatoria, ineficiente, arbitraria y lenta. ${ }^{63}$

\footnotetext{
${ }^{61}$ LÓPEZ, "Formas Alternativas", cit. nota $\mathrm{n}^{\circ}$ 44; LILLO, R., "Conflictos ambientales en territorios indígenas", Revista CREA, No2 (2002), pp. 70-112.

${ }^{62}$ VALENCIA, A.; DÍAZ, A., "El proyecto "Centro de Resolución Alternativa de Conflictos-CREA"”, Revista CREA, No 1 (2000), pp. 7-9.

${ }^{63}$ BARROS, L., Justicia y Marginalidad Rural, DESUC, Santiago: CDJ-CPU, 1994; CORREA, J.; JIMENEZ, M.A., Sistema Judicial y Pobreza. Estudio sobre el acceso a la justicia, Cuadernos de Análisis
} 
DÍAZ, ALEJANDRA. "La experiencia de la mediación penal en Chile".

- Fomentar la desjudicialización de los conflictos, promoviendo soluciones menos costosas, y más democráticas, y

- Capacitar a los operadores del sistema de justicia y a la comunidad en general, en técnicas que reforzaran la eficacia de las reformas legales vigentes y aquellas que serían pronto aprobadas, todas las cuales contemplaban mecanismos de RAC.

Nació así la idea de la creación del Centro como un ente difusor, capacitador, investigador y gestionador de mecanismos de resolución alternativa de conflictos, el que, junto con incorporar el elemento educativo en su misión, se propuso tener un impacto social en la comunidad, prestando servicios de mediación a la misma, lo que, junto con contribuir a una cultura de diálogo, permitiría formar a otros mediadores mediante experiencias clínicas o de pasantías.

La Escuela de Derecho ha incorporado en sus curriculums de enseñanza el aprendizaje de la RAC y mediación, y a través del Centro se ha capacitado a numerosos abogados, psicólogos y asistentes sociales en mediación, y ha realizado numerosos Congresos y Seminarios sobre la materia. Asimismo, anualmente se publica una Revista especializada en resolución de conflictos, la "Revista CREA".

El Centro de mediación propiamente tal comenzó a operar la mediación familiar, pero abarcando también conflictos laborales, vecinales e indígenas. Tiene un equipo multidisciplinario de mediadores, compuesto por abogados, psicólogos y asistentes sociales. Con el inicio de la Reforma Procesal Penal en la región en el año 2000, se comienza a intervenir también en mediación penal. Sin embargo, los casos penales que han mediado hasta la fecha son muy pocos, siendo varios de ellos realizados en la Fiscalía de Angol. En estos casos, los mediadores se trasladan a la Fiscalía y realizan la mediación, generalmente, en la misma sede de la Fiscalía Local, siendo la derivación de casos realizadas por las/los asistentes de fiscal. Los casos penales que ingresan son generalmente delitos menores donde, en general, existe una relación previa entre las partes (de vecindad o familiar). Desde el año 2001 al año 2003, ingresaron 19 casos penales, siendo sus fuentes de derivación: la Fiscalía Local (11 causas), la Unidad Regional de Atención a Víctimas y Testigos (3 causas), la Defensoría Penal (2 causas) y los Juzgados de Garantía (3 causas). Se trataba de delitos de lesiones, daños y amenazas básicamente, algunos de los cuales tuvieron aplicación de principio de oportunidad, facultad de no iniciar investigación del fiscal, archivo provisional, y salidas alternativas. De los 19 ingresos, 12 fueron mediados, de los cuales en 9 se llegó a acuerdo. ${ }^{64}$

Jurídico No 35, Serie Seminarios, Santiago de Chile: Universidad Diego Portales, 1997; CORREA, J.; JIMENEZ, M.A.; LEÓN MONCAYO, H.; Equipo de investigadores del IBAM, Acceso de los pobres a la justicia en países de América Latina. PNUD, Colección Estudios Urbanos, Ed. SUR, 1995.

${ }^{64}$ LAGOS, S., "Experiencias de Mediación Penal", Ponencia presentada para el Seminario La mediación, instrumento de paz social en distintos ámbitos: penal, laboral, familiar e infancia, Temuco, 21 de noviembre de 2003. 
Polít. crim. Vol. 5, No 9 (Julio 2010), Art. 1, pp. 1-68.

[http://www.politicacriminal.cl/Vol_05/n_09/Vol5N9A1.pdf]

Procedimiento o modelo utilizado:

El Centro no aplica un procedimiento o modelo de mediación penal específico, sino que más bien aplica el mismo modelo que se usa en las mediaciones familiares, adaptándolo a las situaciones del caso concreto. A su vez, este modelo combina distintos elementos de los modelos de mediación existentes (circular narrativo, tradicional lineal, y transformativo). El Centro ha inscrito su modelo de mediación penal dentro del marco de la justicia restaurativa ${ }^{65}$. La mediación puede durar dos o más sesiones, siendo lo común que dure de tres a cuatro sesiones. En la primera sesión se cita a ambas partes y se toma conocimiento de los hechos, se realiza un encuadre a las partes, y se les informa que el proceso es confidencial y voluntario. Todas las mediaciones penales realizadas por el Centro implican un encuentro personal entre víctima e imputado. Al finalizar la mediación, se entrega un informe al fiscal, que contiene la estructura del acuerdo (resguardándose el principio de confidencialidad de la mediación), o la información de que no se llegó a acuerdo, siendo éste el momento de cierre de la mediación. Todo lo que ocurra después con el caso, si el fiscal decide o no formalizar y no oponerse al acuerdo reparatorio, es facultativo del fiscal y el Centro no tiene intervención en ello. No se hace un seguimiento del caso por parte del Centro, como sí ocurre en materia de conflictos de familia. Finalmente, no existe un procedimiento de coordinación formal entre el Centro y la Fiscalía de Temuco, en donde se hayan protocolizado los pasos a seguir por parte del fiscal una vez que las partes han llegado a acuerdo.

c) Otras iniciativas surgidas desde la sociedad civil en RAC y mediación.

Sin ser exhaustivo, se pueden destacar las siguientes iniciativas al respecto: El Programa Conversando es Mejor: Resolución de Conflictos en la Escuela, impulsado por la Fundación de Ayuda Social de Iglesias Cristianas (FASIC), e implementado entre los años 2001-2005, involucrando a tres escuelas de la comuna de Huechuraba, jardines infantiles de la comuna de Cerro Navia (apoderados y organizaciones de base) y organizaciones de base de la comuna de Pudahuel, y en la que se realizaron charlas, seminarios y talleres, dirigidos a estudiantes, docentes y apoderados, acerca de habilidades para el diálogo, la actitud pacífica frente a los conflictos, y la importancia de la comunicación en las relaciones humanas; el trabajo que desde hace décadas viene desarrollando la Organización no Gubernamental (ONG) FORJA en la difusión de las RAC y en la formación de líderes comunitarios con capacidad para ejercer como conciliadores o pacificadores en sus comunidades; el trabajo desarrollado por la ONG Casa de la Paz; por el Instituto de Terapia Familiar; por el Centro de Mediación Familiar de la Florida, dependiente de la Fundación de Asistencia Social y Legal de la Familia; y, por último, la experiencia de los centros de mediación vecinales apoyados por las Municipalidades y el Ministerio del Interior, tales como: el Centro de Mediación de la Municipalidad de El Bosque, y el Centro de Orientación y Resolución de Conflictos Vecinales de la Comuna de Cerro Navia, impulsada por la Fundación de Ayuda Social de Iglesias Cristianas (FASIC), y que es parte del

\footnotetext{
${ }^{65}$ LAGOS, “Experiencias de Mediación Penal”, cit. nota n 64 .
} 
DÍAZ, ALEJANDRA. "La experiencia de la mediación penal en Chile".

Programa Comuna Segura 2006 de la Municipalidad de Cerro Navia - Ministerio del Interior.

Además de estas iniciativas, son varias las Universidades, Centros e Institutos que actualmente capacitan y/o han capacitado en los mecanismos de resolución alternativa de conflictos, sea incorporándolos en su currículo de enseñanza de pregrado, sea impartiendo cursos de especialización y/o postítulos, con docentes nacionales y/o extranjeros, entre los que cabe mencionar: el Centro de Mediación y Negociación de la Universidad Católica, el Centro CREA de la Universidad Católica de Temuco, el Instituto Carlos Casanueva, el Instituto de Terapia Familiar, la Universidad Bolivariana, la Universidad Central y la Universidad Diego Portales, la Facultad de Educación de la Universidad Mayor, entre otros.

Estos desarrollos permiten afirmar que en Chile existe hoy un movimiento de RAC o MARC, vinculado a distintos valores tales como el acceso a la justicia, la modernización del Estado, la promoción de una cultura de diálogo y de paz, la descentralización de la justicia y la reducción de sobrecarga de los tribunales, entre otros. Este movimiento RAC se conecta con, y nutre el desarrollo de la mediación penal en Chile, si bien ésta, como se verá, también surge vinculada a otros movimientos sociales y pensamientos jurídicos paralelos. Esta conexión, sin embargo, a veces conlleva problemas, cuando se pretende trasladar de manera casi automática los principios y prácticas de la mediación familiar al ámbito penal. La mediación penal comparte técnicas y principios con la mediación civil, pero también posee sus propios principios, que mucho tienen que ver con la necesidad de considerar los elementos y características propias del sistema penal en el cual ésta última se desenvuelve. Entre estas características, una de las más relevantes es el elemento de "coerción", el cual obliga a considerar de manera más exhaustiva el problema de los límites y garantías para el imputado u ofensor en la mediación penal, así como los posibles efectos que la misma pueda tener en la ampliación de la red de control social.

Otra diferencia importante, dice relación con que en la mediación familiar y civil, se trata de la negociación y/o conciliación de intereses y necesidades de las partes. En cambio, en la mediación penal, si bien incluye el elemento de negociación de intereses, se parte de una premisa totalmente distinta, por cuanto requiere del reconocimiento por parte del infractor u ofensor de que éste ha cometido una injusticia en contra de la víctima (aunque dicho reconocimiento no tenga relevancia jurídico-penal, en el sentido de que no signifique necesariamente "reconocer culpabilidad penal", Es decir, la mediación penal, especialmente en aquellos modelos que persiguen la reconciliación de las relaciones personales, como el modelo VORP (Programas de Reconciliación Víctima-Infractor) desarrollado en Canadá y Estados Unidos, ${ }^{66}$ requiere del reconocimiento por parte del autor de los hechos materia de la imputación y/o del reconocimiento de haber cometido un hecho que ha causado un daño o perjuicio a una víctima real y concreta. La mediación penal opera, así, sobre la base del reconocimiento de la condición de víctima que afecta a una de las partes en el conflicto. Así, se puede incluso sostener que en la mediación penal existe un juicio de "denuncia" que

${ }^{66}$ ZEHR, H., Changing Lenses: A New Focus for Crime and Justice, Pennsylvania: Herald Press, 1990. 
Polít. crim. Vol. 5, No 9 (Julio 2010), Art. 1, pp. 1-68.

[http://www.politicacriminal.cl/Vol_05/n_09/Vol5N9A1.pdf]

es condición de la celebración de cualquier acuerdo entre las partes, lo cual no encuentra un equivalente dentro de la mediación civil o familiar. ${ }^{67}$

\subsection{La incorporación de las necesidades e intereses de las víctimas en el proceso penal.}

Una segunda tendencia que favorece la incorporación de la mediación penal en Chile es la preocupación que en las últimas décadas se ha producido por las necesidades e intereses de las víctimas de delitos, de manera similar, aunque posterior, a lo sucedido en otros países (Estados Unidos, Canadá, Reino Unido y Europa Continental) en donde el movimiento por los derechos de las víctimas ha tenido un significativo impacto en las legislaciones de esos países. ${ }^{68}$ En Chile, esta tendencia se ha manifestado en diversas reformas legales que otorgan más derechos a las víctimas en el proceso penal, buscando ampliar las posibilidades de participación de éstas en el proceso, de recibir reparación por los daños morales, materiales y psicológicos causados por el delito, y de recibir medidas de protección durante el curso del proceso, así como en la creación de diversos servicios e instituciones que proporcionan ayuda y asistencia social, material y de salud a las víctimas de delitos.

Así, por ejemplo, en el Código Procesal Penal de 2000, que introdujo la reforma procesal penal en Chile, se incorpora por primera vez una norma específica (Artículo 109) que establece los derechos de las víctimas. Si bien antes de la reforma procesal penal, las víctimas en Chile podían querellarse, ejerciendo la acción penal en contra del imputado, con la reforma procesal penal no sólo subsiste este derecho sino que, además, se consagran una serie de otros derechos que pueden ejercer las víctimas por sí mismas, aunque no se hayan constituido en querellantes en el proceso penal. Entre estos derechos, destacan: a) el derecho a ser oída, si lo solicitare, por el fiscal, antes de poner término al procedimiento por cualquiera de los términos facultativos del fiscal, así como de la suspensión condicional del procedimiento, b) el derecho a ser oída por el tribunal antes de que se ponga término anticipado al procedimiento y se decrete el sobreseimiento temporal o definitivo de la causa, y c) el derecho a impugnar la sentencia absolutoria aun cuando la víctima no hubiere intervenido previamente en el procedimiento.

Una diferencia interesante entre el fenómeno de incorporación de derechos de las víctimas en el proceso penal en Chile, en comparación con la evolución en países anglosajones y algunos países de Europa Continental, es que en éstos un antecedente importante de creación de estos derechos tenía que ver con la crítica que se hacía al sistema penal en cuanto a que la víctima era algo así como "el actor olvidado" del proceso penal, pues ésta era convocada como testigo, siendo muchas veces su declaración un elemento clave para obtener la condena del imputado, pero no se le otorgaban derechos de participación en el

\footnotetext{
${ }^{67}$ DÍAZ, A., "La Mediación Penal y los Acuerdos Reparatorios: Potencialidades de Aplicación y Principios Involucrados", Ponencia presentada en III Encuentro Iberoamericano de Resolución Alternativa de Conflictos, Viña del Mar, 22 al 24 de Septiembre de 2004, p. 9, en: http://www.redesalternativas.com/notas.htm; http://www.restorativejustice.org

${ }^{68}$ DÍAZ, A., "La Influencia del Movimiento Pro-Víctimas en la Justicia Restaurativa", Revista CREA, Vol. 4 (2003), pp. 195-212; ELÍAS, R., "Community Control, Criminal Justice and Victim Services", en: FATTAH, E.A. (Ed.) Towards a Critical Victimology, London: The Macmillan Press, 1992, pp. 373-395.
} 
DÍAZ, ALEJANDRA. "La experiencia de la mediación penal en Chile".

proceso, el cual, en ocasiones iba incluso en contra de sus intereses concretos. Esta crítica se fundamentaba en gran parte en el hecho de que no existía en tales sistemas jurídicos la figura del querellante particular, teniendo el fiscal el monopolio de la persecución penal pública. Esto nunca fue así en Chile, pues siempre la víctima pudo ejercer la querella, y con la reforma procesal penal este derecho se mantuvo, incorporando, además, nuevos derechos de participación para las víctimas de delitos, que pueden ejercer aún cuando no se constituyan en querellantes

Los acuerdos reparatorios son una expresión clara de la incorporación de los intereses de las víctimas en el proceso penal. También lo es la suspensión condicional del procedimiento, al incorporar entre las posibles condiciones a cumplir por el imputado, la de indemnizar a la víctima (Art. 238 letra e) CPP).

\subsection{La justicia restaurativa.}

En tercer lugar, la idea de mediación penal ingresa a Chile y/o es gradualmente asociada por parte de algunos autores y promotores de la misma, a la teoría de la justicia restaurativa, siendo la mediación penal concebida, en general, como una técnica, estrategia o práctica específica de justicia restaurativa. ${ }^{69}$ Esto ha tenido lugar a medida que el medio nacional ha ido progresivamente conociendo esta teoría a través de diversos artículos en español e inglés, conferencias y seminarios.

La identificación clara entre mediación penal y justicia restaurativa se ha dado, sin embargo, sólo en la presente década e, incluso, podría decirse, con especial fuerza en los últimos cinco años. Puede decirse, sin temor a exagerar, que la justicia restaurativa recién viene instalándose en Chile, siendo un movimiento muy incipiente. Así, algunos autores nacionales comienzan a identificar a la institución de los acuerdos reparatorios con la justicia restaurativa ${ }^{70} \mathrm{y}$, en menor medida, identifican también a la SCP con esta forma de justicia $^{71}$, la conciliación contemplada en los delitos de acción penal privada, tales como los

\footnotetext{
${ }^{69}$ Así, ver: DÍAZ, cit. nota $\mathrm{n}^{\circ} 67$; BLANCO/DÍAZ/HESKIA/ROJAS, Infra nota $\mathrm{n}^{\circ} 70$.

${ }^{70}$ MORALES, A.M., "Las salidas alternativas y las sanciones no privativas de libertad de reparación del daño y servicios en beneficio de la comunidad en el subsistema de responsabilidad penal de adolescentes infractores de la ley penal", Revista de Estudios de la Justicia, No 7 (2006), pp. 159-182; BLANCO, R.; DIAZ, A.; HESKIA, J.; ROJAS, H., Justicia Restaurativa: Marco Teórico, Experiencias Comparadas y Propuestas de Política Pública, Santiago de Chile: Universidad Alberto Hurtado, 2004; DÍAZ, A., "Justicia Restaurativa: Concepto y Modelos Prácticos", Boletín Jurídico, Ministerio de Justicia, Santiago de Chile, 2004; CARNEVALI, "Las políticas de orientación a la víctima", cit. nota $\mathrm{n}^{\circ}$ 43; TSUKAME, A., "Mediación y Responsabilidad Penal del Adolescente", Ponencia presentada en III Encuentro Iberoamericano de Resolución Alternativa de Conflictos, Viña del Mar, 22 al 24 de Septiembre de 2004, en: http:// www.redesalternativas.com/notas.htm

${ }^{71}$ MORALES, "Las salidas alternativas", cit. nota $\mathrm{n}^{\circ}$ 70; BLANCO/DÍAZ/HESKIA/ROJAS, Justicia Restaurativa, cit. nota $\mathrm{n}^{\mathrm{0}} 70$, quienes admiten la posibilidad de incorporar la justicia restaurativa en el marco de la SCP, pero en menor medida que en el caso de los acuerdos reparatorios, que es visto como la institución procesal penal que se identifica o que manifiesta los valores y principios de la justicia restaurativa con mayor fuerza y claridad; DÍAZ, A., "Justicia Restaurativa: Concepto y Modelos Prácticos", Boletín Jurídico, Ministerio de Justicia, Santiago de Chile, 2004.
} 
Polít. crim. Vol. 5, No 9 (Julio 2010), Art. 1, pp. 1-68.

[http://www.politicacriminal.cl/Vol_05/n_09/Vol5N9A1.pdf]

delitos de injuria y calumnia - Art. $404 \mathrm{CPP},{ }^{72}$ y el principio de oportunidad como mecanismo que hace posible o abre la puerta para la eventual incorporación de procesos restaurativos en él. ${ }^{73}$

Incluso, recientemente, se ha articulado el concepto de "mediación penal restaurativa". Por ejemplo, este concepto es planteado en la Mesa de Trabajo sobre Mediación Penal, implementada por el Ministerio de Justicia. ${ }^{74}$ El concepto que entrega la Mesa de Trabajo es interesante, especialmente si lo contrastamos con el concepto de mediación que se ha manejado en el medio nacional hasta ahora, que como decíamos, se aplicaba especialmente en el ámbito de familia ${ }^{75}$. Entienden por mediación penal restaurativa: "Un plan de acción para la solución de un conflicto penal que aborda y repara el daño causado a una víctima o a su familia por un delito, falta o conducta abusiva que afecta sus derechos", y:

"Es un proceso de solución de conflictos penales guiado por un tercero imparcial, en el que las partes participan voluntariamente, buscando en forma colaborativa el restablecimiento del equilibrio roto por la transgresión ocasionada por un delito, falta u ofensa, mediante la restauración de sus consecuencias y la reconciliación de las personas afectadas".

En esta definición destacan la presencia de ciertos valores propios de algunas tradiciones de justicia restaurativa, como es el caso de la "reconciliación", así como los elementos explícitamente penales incorporados a la definición de mediación. Esto último tiene consecuencias prácticas importantes en el diseño y metodología de la mediación. Por ejemplo, se agregan nuevos principios que no estaban mencionados regularmente por el movimiento de RAC como integrantes de la mediación, y que ciertamente tampoco lo están entre los principios de la mediación establecidos en la ley de tribunales de familia. Así, a los principios clásicos de la mediación, tales como la voluntariedad, la confidencialidad y la imparcialidad o neutralidad del mediador, se añaden: la responsabilización del infractor, la reparación a la víctima, la adecuación del proceso a la situación de vulnerabilidad de la víctima y la consideración de las posibilidades de reparación del infractor.

Asimismo, en cuanto al perfil del mediador, se agregan elementos distintivos, como por ejemplo, que el mediador tenga especial empatía hacia la víctima, que tenga formación en criminología y victimología, entre otros. Esta concepción de la mediación penal restaurativa refleja el avance de las concepciones sobre mediación penal en el medio nacional hacia las concepciones propias de la justicia restaurativa.

\footnotetext{
${ }^{72}$ CARNEVALI, "Las políticas de orientación a la víctima", cit. nota ${ }^{\circ} 43$.

${ }^{73}$ DÍAZ, A., "Justicia Restaurativa: Concepto", cit. nota n 70.

${ }^{74}$ GONZÁLES, I.; CASTILLO, A.D.; DE LAS HERAS, M.J., "Mediación penal y justicia restaurativa en Chile", 2006, en http://www.accesoalajusticia.cl/webjusticia/nuevos/docs/mediacionpenalyjusticiaII.pdf, [visitado en Diciembre de 2008].

${ }^{75}$ Ver Par. IV, 1.4.
} 
DÍAZ, ALEJANDRA. "La experiencia de la mediación penal en Chile".

Los conceptos de justicia restaurativa planteados hasta ahora en el medio nacional, abarcan desde la definición general de Tony Marshall ${ }^{76}$ hasta el concepto de Lode Walgrave ${ }^{77}$ y su propuesta de énfasis no sólo en los procesos sino que también en los resultados; la mirada puesta en "los valores" de la justicia restaurativa de los autores Van Ness y Strong. ${ }^{78}$ la teoría de la "vergüenza reintegradora" de John Braithwaite ${ }^{79}$ y, el planteamiento de Howard Zehr con su énfasis en la reconciliación de relaciones, así como su ilustrativo contraste entre la justicia retributiva y restaurativa. ${ }^{80}$ También es posible apreciar en el medio nacional propuestas de justicia restaurativa que enfatizan la idea de responsabilización del infractor y los aspectos educativos de la misma, ${ }^{81}$ ámbito en el cual se cita también a autores continentales europeos como el español Jaume Funes. ${ }^{82}$ Los planteamientos sobre la devolución del conflicto a los directamente implicados en la comisión del delito que tienen su origen en el abolicionismo también han sido acogidos en el medio nacional, así como las nociones de la justicia restaurativa como una justicia holística, que involucra no sólo al infractor y a la víctima, sino que a la sociedad toda, la cual comparte cierta responsabilidad en la comisión de la ofensa $y$, por tanto, también en la restauración. Las definiciones contenidas en instrumentos internacionales sobre la materia, como la Declaración de la ONU sobre Principios de Justicia Restaurativa en materia penal, también han sido incorporados en las propuestas sobre el desarrollo de la justicia restaurativa y mediación penal en Chile. ${ }^{83}$ Finalmente, se analiza la justicia restaurativa desde los planteamientos y/o reflexiones sobre la misma y sobre la reparación a la víctima provenientes de la dogmática penal de raíz continental europea, que se plantean la posibilidad de vincular a la reparación en el ordenamiento jurídico penal con los fines de la pena ${ }^{84}$ entre los cuales destacan especialmente los planteamientos de Roxin.

\footnotetext{
${ }^{76}$ DÍAZ, "La Mediación Penal y los Acuerdos Reparatorios", cit. nota nº 67.

${ }^{77}$ WALGRAVE, "Extending the Victim Perspective", cit. nota no 6.

78 VAN NESS/STRONG, Restoring Justice, cit. nota $n^{\circ}$ 9; BLANCO/DÍAZ/HESKIA/ROJAS, Justicia Restaurativa, cit. nota $\mathrm{n}^{\circ} 70$.

${ }^{79}$ FRIEDMAN, L., "Justicia restaurativa. Nuevas formas de tratamiento para delincuentes juveniles", 2007, en: http://www.cienciaspenales.net

${ }^{80}$ BLANCO/DÍAZ/HESKIA/ROJAS, Justicia Restaurativa, cit. nota $\mathrm{n}^{\circ}$ 70; CAMPOS, H., "Reflexiones en torno a la incorporación de estrategias restaurativas en nuestro país" Ponencia presentada en III Encuentro Iberoamericano de Resolución Alternativa de Conflictos, Viña del Mar, 22 al 24 de Septiembre de 2004, en: http://www.redesalternativas.com/notas.htm

${ }^{81}$ La vinculación entre justicia restaurativa y la educación se da especialmente en el ámbito de la justicia juvenil. Así, por ejemplo, esta vinculación se encuentra presente en las Orientaciones Técnicas para la Sanción de Reparación del Daño, elaboradas por el Servicio Nacional de Menores, servicio encargado de administrar la ejecución de las sanciones juveniles.

${ }^{82}$ FUNES, J., Mediación y Justicia Juvenil, Barcelona: Fundación Jaume Callís, 1995.

${ }^{83}$ VIAL, P., "La justicia restaurativa y la justicia juvenil en Chile: Una perspectiva desde la Defensoría Penal Pública", Ponencia presentada en Seminario Justicia Juvenil: una Visión Restaurativa, Santiago de Chile, 17 y 18 de Noviembre de 2008. Ver también, las Orientaciones Técnicas para la Sanción de Reparación del Daño, SENAME, Febrero de 2007.

${ }^{84}$ MORALES, "Las salidas alternativas", cit. nota ${ }^{\circ} 70$.
} 
Polít. crim. Vol. 5, No 9 (Julio 2010), Art. 1, pp. 1-68.

[http://www.politicacriminal.cl/Vol_05/n_09/Vol5N9A1.pdf]

Algunas de las prevenciones que se han señalado en la incipiente literatura chilena respecto a la justicia restaurativa y la incorporación de salidas alternativas en el sistema penal, han sido: ${ }^{85}$

- En una sociedad desigual como la chilena, los poderosos tendrán siempre acceso a esta salida, quedando el instrumento penal reservado para los más débiles y con menos recursos económicos. ${ }^{86}$

- Al considerarse los intereses de las víctimas actuales en reparación, por sobre los de las víctimas potenciales en la prevención de delitos futuros (función de prevención general positiva de la pena), se privatiza un conflicto que ha sido calificado previamente como penal, es decir, respecto del que se ha manifestado públicamente su afección a bienes jurídico-penales, que expresan intereses de relevancia social. El delito, así, no es un conflicto de estructura dual, sino que tiene trascendencia general, que va más allá de la víctima actual. Uno de los problemas con los mecanismos de mediación penal, es que no estaría comprobada su eficacia preventivo general, de estabilización de la norma, de manera que podrían estar implicando el sacrificio de los intereses de las víctimas potenciales y de los fines de prevención general positiva de la pena ${ }^{87}$. Se plantea, en este ámbito, que si el conflicto fue considerado no merecedor de pena punitiva, siendo derivado al proceso de mediación penal, quiere decir que, o no es un conflicto de tanta relevancia, o bien, que la pena punitiva es ineficaz para dichos casos. En cualquiera de las dos situaciones, la pregunta que cabe hacerse es; ¿por qué, mejor, no despenalizar la conducta? En definitiva, se cuestiona la factibilidad de incorporar estos mecanismos dentro de la esfera del derecho penal, planteándose como mejor opción que operen fuera del mismo. ${ }^{88}$.

- Posibles efectos de extensión de la red de control social a delitos de escasa gravedad. ${ }^{89}$ En este sentido, se plantea que si bien estos mecanismos surgen, en gran medida, desde movimientos y perspectivas teóricas de crítica al sistema penal punitivo, en la práctica, en lugar de reemplazar a la pena punitiva estatal, lo que hacen es ampliar la capacidad del Estado para procesar y controlar conflictos de escasa gravedad que, de no existir el mecanismo informal de resolución de conflictos, no habrían podido ser absorbidos por los aparatos de persecución penal en razón de la imposibilidad de los mismos para dar respuesta a todos los delitos que se cometen en la sociedad.

- La justicia restaurativa sería irreconciliable con el proceso "civilizatorio" que estaría viviendo el país. Este planteamiento ha sido expresado por Cristián Riego. ${ }^{90}$ Según

\footnotetext{
${ }^{85}$ Algunas de estas prevenciones o críticas son planteadas por autores que apoyan la idea de justicia restaurativa, y otros que la rechazan.

${ }^{86}$ HORWITZ/LÓPEZ, Derecho Procesal Penal Chileno, cit. nota no 16.

${ }^{87}$ CARNEVALI, "Las políticas de orientación a la víctima", cit. nota ${ }^{\circ} 43$, p. 14.

${ }^{88}$ CARNEVALI, "Las políticas de orientación a la víctima", cit. nota n ${ }^{\circ} 43, p .17$.

${ }^{89} \mathrm{BLANCO} / \mathrm{DII} A Z / \mathrm{HESKIA} / \mathrm{ROJAS}$, Justicia Restaurativa, cit. nota $\mathrm{n}^{\circ} 70$.

${ }^{90}$ Entrevista a Cristián Riego, académico y penalista chileno, en Tesis de Grado, Alejandra Díaz Gude, 2004, Cap.10.
} 
DÍAZ, ALEJANDRA. "La experiencia de la mediación penal en Chile".

Riego, Chile estaría actualmente atravesando por un proceso "civilizatorio", que estaría ocurriendo de manera violenta, involucrando la eliminación de ciertas formas de vida que se apartan de la moral dominante, siendo la población delincuente una de ellas. El Estado no estaría "integrando" estas otras formas de vida, sino que las estaría eliminando. Este proceso ya habría tenido lugar en Europa, y una vez que para ellos se acabó la amenaza, entonces se sentaron a la mesa y dijeron "bueno, conversemos". La justicia restaurativa habría surgido en países de Europa y, según Riego; "una vez que el proceso civilizatorio estuvo completo, y se aplicó a un tipo de criminalidad más relacionada con problemas de conducta que con pobreza, como sería este último, el caso de Chile y Latinoamérica. Esta circunstancia, impide que en Chile tenga lugar un diálogo genuino, como el propuesto por la justicia restaurativa. En Latinoamérica y en Chile concretamente, la gran cantidad de los delitos, se relaciona con marginalidad, con que las personas roban para sobrevivir, y en ese marco, no hay negociación posible, porque cómo lo vas a hacer entender al tipo de que no es justo que haya robado la radio del auto de un tipo que tiene dos autos, regia casa, etc. Ahí, los intereses son irreconciliables, porque para el del auto, a su vez, no va a aceptar que sea justo que le roben la radio. Ahí lo que habría que hacer, en justicia, es que el rico u otro le pasara plata al ladrón".

- Otra crítica plantea que la justicia restaurativa no sería apropiada en un sistema procesal penal que, como el chileno, ha entregado amplios poderes a la víctima para oponerse a las decisiones facultativas del fiscal de no continuar con la persecución penal. Ello es así, porque en el contexto de una negociación o conciliación, la víctima podría usar esos poderes como un instrumento de extorsión en contra del imputado para obtener reparación económica. Se estaría usando al aparato coercitivo estatal al servicio de la satisfacción de los intereses privados de la víctima. ${ }^{91}$ Conforme a Soto:

"En un sistema en el cual la acción punitiva pertenezca sólo al Estado, la pretensión de
reparación por parte de la victima excluye a la pena, en cambio aquí va todo junto, por
la forma como fue reglamentado en el nuevo Código Procesal Penal. Eso distorsiona
toda la percepción de la función de la víctima, que pasa a ser titular no solo de la
pretensión reparadora, sino también punitiva. Por lo tanto, la renuncia a la acción
penal no depende tan sólo de consideraciones estatales, de fines públicos, sino también
de fines privados. Luego dependerá de la victima la consideración de la suficiencia, de
la conveniencia, de la persecución penal. En ese contexto, la reparación no cumple una
función minimizadora de la represión, sino que incluso puede cumplir una función de
aumento de ésta."

Para otro autor, ${ }^{92}$ este problema aparecería más bien en delitos de ofensores adultos, típicamente económicos, y no en causas juveniles.

\footnotetext{
${ }^{91}$ Entrevista a Miguel Soto, académico y abogado penalista chileno, en DÍAZ, Alejandra, Tesis doctoral, (2004c), Cap.10.

${ }_{92}$ Entrevista a Jaime Couso, académico y experto en justicia juvenil chileno, en DÍAZ, cit. nota ${ }^{\circ} 91$.
} 
Polít. crim. Vol. 5, No 9 (Julio 2010), Art. 1, pp. 1-68.

[http://www.politicacriminal.cl/Vol_05/n_09/Vol5N9A1.pdf]

- Vinculado a lo anterior, se plantea el problema de que la justicia restaurativa puede implicar una dilución de las fronteras del derecho penal, con expansión encubierta del derecho penal y rebaja de garantías, dado el contexto informal en que ésta tiene lugar, lo que favorecería relajar las garantías del debido proceso, pero alcanzando resultados que son similares a la pena, en términos de restricción de derechos al imputado. ${ }^{93}$

El panorama nacional refleja que se están suscribiendo y/o adoptando diversos conceptos sobre justicia restaurativa por parte de académicos y operadores de justicia, que se caracterizan por su diversidad y, muchas veces, por las tensiones entre ellos. No obstante, no es posible afirmar aún que existan tradiciones de justicia restaurativa propiamente tal asentadas en Chile, como sí existen en otros países como Estados Unidos, Inglaterra, y países de Europa Continental, y el debate en torno al tema es aún incipiente.

Habiendo analizado los distintos movimientos, tendencias y teorías que sustentan el desarrollo de la mediación penal en Chile, a continuación, se describirán someramente los proyectos que se han implementado específicamente para el desarrollo de la mediación penal, así como las prácticas desarrolladas por los operadores en el ámbito de la justicia restaurativa.

\section{Proyectos y prácticas específicas sobre Mediación Penal.}

Como se ha señalado previamente, la mediación penal para adultos ha tenido lugar básicamente en el contexto de los acuerdos reparatorios, bajo distintas modalidades, y se han llevado a cabo ya sea en las Fiscalías Locales o en Centros de Mediación externos a los cuales han llegado casos derivados, principalmente, desde las Fiscalías, y/o a instancias de los Defensores. En las Fiscalías Locales, si bien la mediación penal ha sido una de las técnicas de resolución alternativa de conflictos utilizadas para concluir acuerdos reparatorios, ésta ha sido, numéricamente, la menos significativa.

El Fiscal es naturalmente la institución que mayor posibilidad tiene de promover acuerdos reparatorios y hacer derivaciones de casos a centros externos de mediación penal, como lo demuestra la evidencia empírica en todo el mundo, y en razón del contacto y acceso que éste tiene con la víctima. Además, en Chile, el apoyo del Fiscal a esta figura es importante porque éste posee la facultad legal de oponerse a la celebración de acuerdos reparatorios en la audiencia de aprobación judicial, si bien el juez puede aprobar los acuerdos aún en contra de la voluntad del fiscal. Además, el Código Procesal Penal establece en su Art. 6 inciso $2^{\circ}$ que el Ministerio Público tiene el deber de "promover acuerdos patrimoniales, medidas cautelares u otros mecanismos que faciliten la reparación del daño causado a la víctima", con lo cual existe una base legal importante para la promoción de los acuerdos por parte de los Fiscales.

\footnotetext{
${ }^{93}$ Entre quienes plantean esta crítica: Miguel Soto, en DÍAZ, Alejandra, "The Growth of an International Restorative Justice Movement: Some Implications for Juvenile Justice in Chile", Phd Thesis, University of Leeds, 2004, The British Library, Dewey class. no. 345.8308 22, en: The British Library Electronic Online System (EThOS) http://ethos.bl.uk/ViewTerms.do 416554
} 
DÍAZ, ALEJANDRA. "La experiencia de la mediación penal en Chile".

El Oficio $\mathrm{N}^{\circ} 38$ del Fiscal Nacional (21 de enero de 2003) establece la forma o procedimiento de RAC que se utilizará por los fiscales en la celebración de acuerdos reparatorios, señalando las siguientes alternativas de actuación:

El fiscal puede derivar el caso a la Unidad Regional de Atención de Víctimas y Testigos de la Fiscalía ${ }^{94}$ (en adelante, URAVIT) a fin de que informe acerca de la factibilidad de alcanzar esta medida o bien, para que conduzca un proceso de mediación o de conciliación entre las partes;

El fiscal puede derivar el caso a un servicio o programa de mediación externo a la fiscalía, si hubiere alguno en la región;

El fiscal puede coadyuvar a una negociación entre víctima e imputado, pero con la salvedad de que el fiscal no es ni actúa como abogado de la víctima. Se señala expresamente que los fiscales no podrán conducir procesos de mediación penal entre las partes, ya que no son terceros en el conflicto, sino que representan el interés público en la persecución.

Cabe señalar que en los primeros años de la reforma procesal penal, las URAVIT participaron activamente en la celebración de acuerdos reparatorios a través de procesos de mediación y conciliación penal. No obstante, a partir del año 2004-2005 comienza a disminuir la actividad de las URAVIT en estas materias, producto de orientaciones técnicas nacionales que veían en la conducción de procesos conciliatorios un alejamiento de la función propia de las URAVIT, así como por una objeción de principios, consistente en que las URAVIT, por su orientación especial hacia la víctima, no cumplirían con el requisito de neutralidad propio del mediador. Desde entonces, la participación de las URAVIT en procesos de mediación penal y conciliación ha disminuido considerablemente.

Las instrucciones generales de actuación contenidas en el Oficio $\mathrm{FN} \mathrm{N}^{\circ} 38$ se han traducido en la práctica en la aplicación de diversas técnicas de resolución de conflictos por parte de los Fiscales, operando de la siguiente forma:

\subsection{Acuerdos Reparatorios promovidos y celebrados en la Fiscalía Local.}

Suelen tener lugar tempranamente, al inicio del proceso, cuando concurre la víctima a declarar a la fiscalía, o cuando ambos, víctima e imputado, están en la fiscalía en la misma

\footnotetext{
${ }^{94}$ Las URAVIT actualmente están en proceso de cambio en su modelo de intervención, de modo que transitarán de un modelo cuyo objeto fue proporcionar atención integral, psicológica y social a las víctimas de delitos más vulnerables, hacia un modelo centrado en la Orientación (fundamentalmente entrega efectiva de información durante el proceso) la Protección y el Apoyo durante el proceso. Existe una de estas unidades administrativas en cada Región. Están integradas generalmente por un Abogado Jefe, y profesionales sicólogos y asistentes sociales.
} 
Polít. crim. Vol. 5, No 9 (Julio 2010), Art. 1, pp. 1-68.

[http://www.politicacriminal.cl/Vol_05/n_09/Vol5N9A1.pdf]

ocasión. Es el fiscal quien aplica alguna de las técnicas de RAC conocidas, siendo las más comúnmente utilizadas en estos casos la negociación y la mediación penal indirecta. ${ }^{95}$ Prácticamente, no se producen encuentros personales entre las partes. Excepcionalmente, en algunas fiscalías, como en Temuco, sí se promueven encuentros cara a cara entre víctima e imputado.

\subsection{Acuerdos Reparatorios promovidos y celebrados en la Audiencia de Formalización de la Investigación, o en Audiencia Especial citada al efecto.}

Pueden tener lugar al inicio del procedimiento penal, o bien luego de un tiempo de iniciado éste. El fiscal, en estos casos, se acerca primero a la víctima, y luego al imputado, conversando y negociando con ellos de manera separada, llevando y trayendo las propuestas de las partes. La técnica de RAC utilizada por el fiscal en estos casos comparte ciertos componentes característicos de la mediación penal indirecta. Aunque víctima e imputado estén en el mismo lugar físico, no hay una comunicación o diálogo directo entre ellos. El fiscal habla con el imputado en presencia del defensor, pero no necesariamente para incluirlo en las negociaciones, sino más que nada para que actúe como una especie de ministro de fe y transmita confianza al imputado acerca de la seriedad de las conversaciones y de que sus derechos están siendo resguardados. Se ha detectado que el defensor puede ser clave en el éxito de estos acuerdos, al aconsejar a su cliente y transmitirle confianza acerca de la conveniencia de esta salida, así como aclararle las dudas que pueda tener. El fiscal podrá haberse comunicado con el abogado defensor previo a la audiencia, directamente, o bien recomendándole al imputado que converse con su defensor. La promoción del Acuerdo Reparatorio en la audiencia se da de manera bastante informal $\mathrm{y}$, por la agilidad y brevedad de estas audiencias, pueden durar entre 5 a 10 minutos.

También, en muchos casos los acuerdos reparatorios son promovidos por los propios Defensores, generalmente con el apoyo de profesionales de las Unidades de Atención a Testigos e Imputados (en adelante, UATI) de las Defensorías Regionales, que están integradas generalmente por asistentes sociales y psicólogos. Esto sucede, por lo común, cuando la defensa posee antecedentes de las víctimas para contactarlas, como cuando el delito ha tenido lugar entre personas conocidas, y/o cuando los antecedentes de la víctima están en la carpeta del fiscal. En estos casos, el proceso de formación del acuerdo se inicia con anterioridad a la audiencia judicial, y podrá involucrar visitas a terreno y/o contactos telefónicos a víctimas e imputados por parte de los profesionales de las UATI. En ocasiones, estos profesionales también hacen seguimiento del cumplimiento de los acuerdos. En todo caso, las prácticas regionales son variadas, siendo algunas regiones más activas que otras en la promoción de salidas alternativas con la participación de sus profesionales UATI.

\footnotetext{
${ }^{95}$ Proceso de mediación que se diferencia de la mediación directa en que no se produce un "encuentro personal", cara a cara, entre la víctima y el imputado u ofensor, sino que el tercero neutral o mediador hace las veces de intermediario entre uno y otro, visitando a cada parte de manera separada y ayudándoles a expresar sus sentimientos e intereses en relación al conflicto. El tercero, en la mediación indirecta, recibe y transmite los mensajes de cada una de las partes, para finalmente, negociar un acuerdo voluntario entre ellas.
} 
DÍAZ, ALEJANDRA. "La experiencia de la mediación penal en Chile".

\subsection{Acuerdos Reparatorios facilitados por las Unidades Regionales de Atención a Víctimas y Testigos - URAVIT- previa derivación del fiscal.}

Como se señaló previamente, la participación de las URAVIT en los acuerdos reparatorios ha disminuido, pero es relevante mencionar su experiencia por cuanto durante algunos años fueron activas en la implementación de técnicas de RAC, especialmente algunas regiones, como la I y II Regiones del Norte del país, ${ }^{96}$ con lo cual poseen un conocimiento y experiencia acumuladas que puede ser útil de difundir. La técnica de RAC más comúnmente utilizada en las URAVIT para la celebración de acuerdos reparatorios ha sido la conciliación o negociación y la mediación penal indirecta. Al respecto, cabe señalar que para algunos profesionales URAVIT, no es posible hablar de mediación indirecta, sino sólo de negociación o conciliación, por cuanto las URAVIT no reunirían el requisito de neutralidad propio de la mediación, pues ellos representarían más los intereses de la víctima $^{97}$. Otros profesionales estiman que sí realizan mediación penal, pero de un tipo diferente al de la mediación civil o familiar, pues en la penal, habría una opción preferencial por la víctima, lo que además se relacionaría adecuadamente con la orientación de las Unidades hacia las víctimas.

Tanto los fiscales como las URAVIT proponen el AR primero a la víctima, y después al imputado. En la literatura especializada, esta estrategia es vista como útil cuando se quiere evitar una presión a la víctima a aceptar el AR, si el imputado ya ha aceptado (por ej., por temor a represalias). Por otro lado, esto tiene el inconveniente de que puede provocar una doble victimización en la víctima, si ésta ha aceptado la idea de llegar a AR con el imputado, y luego éste declara que no está dispuesto a reparar. ${ }^{98}$

Así, y a diferencia de la lógica de la mediación penal y de los procesos de reconciliación víctima-infractor que tienen lugar en otros países, en la práctica de las fiscalías (y URAVIT) en Chile prácticamente no se promueven encuentros personales entre víctima e imputado, siendo lo más común que se produzcan contactos separados con cada una de las partes involucradas, sea por parte del fiscal, asistente de fiscal, o profesional URAVIT, aunque en ocasiones se dan encuentros personales cuando son las partes las que lo piden y/o quienes llegan autónomamente a un acuerdo. El espacio institucional en el cual sí se han dado encuentros personales entre las partes, es en las mediaciones penales facilitadas por centros externos de mediación penal. Excepcionalmente, sí se realizan encuentros personales o cara a cara entre víctima e imputado en la Fiscalía, como en el caso de la Unidad de Delitos Menores de la Fiscalía de Temuco.

\footnotetext{
${ }^{96}$ En la ciudad de Calama, II Región, se exploró la posibilidad de crear un proyecto piloto para derivar causas a centros de mediación de casas de estudio regionales, como el Instituto INACAP. En la I Región, la URAVIT en Arica era especialmente activa en la celebración de acuerdo reparatorios, debido a las destrezas de una de sus profesionales asistentes sociales.

${ }^{97}$ Conversaciones personales con algunos profesionales URAVIT.

${ }^{98}$ DÍAZ, "La influencia del movimiento pro-víctimas", cit. nota $n^{\circ} 68$.
} 
Polít. crim. Vol. 5, No 9 (Julio 2010), Art. 1, pp. 1-68.

[http://www.politicacriminal.cl/Vol_05/n_09/Vol5N9A1.pdf]

La Defensoría Penal publicó un interesante estudio sobre las salidas alternativas en Diciembre de 2004. ${ }^{99}$ La investigación se llevó a cabo entre noviembre de 2003 y julio de 2004, y comprendió diversas fuentes de recolección de datos, entre ellas, el desarrollo de dos tipos de entrevistas. La primera corresponde al grupo de personas a quienes se les otorgó una salida alternativa y la segunda corresponden a entrevistas en profundidad a jueces de garantía, defensores y fiscales dirigidas a recoger la experiencia que en la práctica tenían con estas salidas.

La primera entrevista de tipo estructurada, se aplicó a 289 personas cuyas causas estaban radicadas en cinco regiones del país, 240 de las cuales habían finalizado suspensión condicional del procedimiento, y 49 un acuerdo reparatorio. Respecto de los resultados obtenidos para los acuerdos reparatorios, se destacan, entre otros, los siguientes:

Perfil social, laboral y familiar de los ofensores: los resultados muestran que dicho perfil no siempre es similar al de la justicia penal en general, y tampoco resulta análogo con el de aquellas personas a quienes se les concedió una SCP. Así, en cuanto al género, el 74\% correspondió a hombres y el $26 \%$ a mujeres, lo que resulta notablemente superior al $6 \%$ que alcanzan las mujeres en la SCP. La edad de las personas oscila entre 30 y 60 años (51\%). El nivel socioeconómico de las personas a quienes se les concedió un AR es más alto que en el caso de la SCP. Todos señalaron tener algún tipo de estudio, un menor porcentaje no había completado su educación media, y un porcentaje mayor tiene estudios universitarios. Este dato es interesante, pues podría estar dando la razón a las críticas que plantean que el AR se podría estar aplicando especialmente para ciertos grupos de la población más aventajados, si bien estas cifras son todavía pequeñas y sería interesante explorar más esta hipótesis en un estudio que abarcara más casos, así como también, que se recogieran datos independientes sobre acuerdos reparatorios de ofensores juveniles. Por otro lado, la mitad de las personas a quienes se les decretó un AR estaban desocupadas al momento de iniciar su cumplimiento. ${ }^{100}$

En cuanto al tipo de delitos por los que se llegó a un AR, un $28 \%$ correspondió a robo y hurto, un $18 \%$ a lesiones leves, y un $14 \%$ a accidentes de tránsito que derivaron en cuasidelito de lesiones. A pesar de que se trata de delitos leves, un $13 \%$ de las personas señaló que cumplió prisión preventiva por períodos que se extienden entre 28 y 90 días.

Ante la pregunta de quién le informó/propuso primero el AR, el 51\% mencionó al defensor, el $37 \%$ al fiscal, y el $12 \%$ a la víctima.

En cuanto a los tipos de acuerdos alcanzados, el primero y más frecuente $(78 \%)$ consistió en el pago de una suma de dinero o de reparación económica, la segunda (12\%) en firmar

\footnotetext{
99 JIMÉNEZ, M.A. (Dir.); SANTOS, T.; HERMOSILLA, G.; SCALIA, P., Las salidas alternativas en el nuevo proceso penal. Estudio exploratorio sobre su aplicación. Santiago de Chile: Centro de Documentación Defensoría Penal Pública, 2004.

${ }^{100}$ La incorporación de la mediación penal en el marco de los acuerdos reparatorios permitiría hacer frente a aquellas críticas hacia la justicia consensuada que la plantean como elitista, en la medida que facilitaría el poder arribar a acuerdos no sólo monetarios, sino que de otro tipo.
} 
DÍAZ, ALEJANDRA. "La experiencia de la mediación penal en Chile".

por un período de tiempo determinado ante alguna autoridad o institución pública, y la tercera $(10 \%)$ consistió en la presentación formal de disculpas a la víctima.

En cuanto al cumplimiento de los acuerdos, se alcanza un alto nivel de cumplimiento, llegando al 96\% de cumplimiento.

En relación al apoyo social recibido, el 85,7\% señaló que su familia lo apoyó cuando supo de esta salida, el 63,2\% señaló que fue apoyado por su jefe, el 5,3\% dijo que el jefe le puso condiciones, el $10,5 \%$ que no pasó nada, y el $21,1 \%$ no respondió a la pregunta sobre la reacción de sus jefes. En cuanto al empleo, el $81 \%$ dijo haber conservado su trabajo producto del juicio que finalizó con un acuerdo reparatorio (en tanto que el 9,5\% lo perdió). ${ }^{101}$

Finalmente, en cuanto a la evaluación de la experiencia, ante la pregunta de ¿qué opina de esta solución de la justicia?, el 73,5\% respondió que era "buena", el 10,2\% que era "regular", y el 16,3\% que era "mala". Entre los que expresaron que era buena, las razones fueron: "es una justicia rápida y sincera", "es una alternativa para no perder la libertad", "posibilita acuerdos y repara el momento vivido". Entre los que la calificaron de regular o mala, las razones fueron: "el proceso duró mucho tiempo", "se imponen medidas que no se respetan", "no hubo una investigación a fondo de los hechos".

El segundo tipo de entrevistas se aplicó a 28 profesionales de la I, III, IV, VII, IX y XI región, que eran actores del nuevo sistema procesal penal -jueces de garantía, defensores y fiscales- y estuvo dirigida a recoger la evaluación que ellos hacían de las salidas alternativas. ${ }^{102}$ En particular, con relación a los acuerdos reparatorios, los resultados muestran que: todos los actores que están involucrados en el acuerdo reparatorio -jueces, defensores, fiscales, imputado y víctima- señalan y valoran el haber tenido una exitosa experiencia con esta salida alternativa (AR). Esto los lleva a coincidir en que debe ser más utilizada, no sólo para los delitos leves como lo prevé la actual normativa, sino para

\footnotetext{
${ }^{101}$ Respecto a esto último, habría que explorar si los casos de personas despedidas corresponden también a aquellas que estuvieron en prisión preventiva, dado que en ese caso sería más probable que el despido se haya debido a esa circunstancia que a la celebración del acuerdo reparatorio.

102 JIMÉNEZ et al, Las Salidas Alternativas en el nuevo proceso penal, cit. nota ${ }^{\circ}$ 99, p. 57. Para los resultados in-extenso de las entrevistas en profundidad a: jueces, defensores y fiscales, sobre medidas cautelares y salidas alternativas, consultar la III Parte de este mismo trabajo: Estudio exploratorio sobre medidas cautelares y salidas alternativas en el nuevo proceso penal, Defensoría Penal Pública, Diciembre 2004.
} 
Polit. crim. Vol. 5, № 9 (Julio 2010), Art. 1, pp. 1-68.

[http://www.politicacriminal.cl/Vol_05/n_09/Vol5N9A1.pdf]

muchos otros delitos que pudieran alcanzar respuestas más satisfactorias para las víctimas y menos gravosa para el imputado.

En definitiva, esta investigación confirma algunos de los beneficios y ventajas de la justicia restaurativa, a la vez que también permite advertir algunas de sus desventajas y/o peligros, los cuales pueden tal vez ser corregidos mediante un adecuado diagnóstico y la implementación de buenas prácticas.

\subsection{Derivación hacia centros externos de mediación penal.}

Finalmente, la cuarta estrategia de celebración de acuerdos reparatorios en las fiscalías consiste en la derivación del caso hacia centros externos de mediación penal, tales como el Centro CREA de la ciudad de Temuco, u otros centros que han funcionado sólo como proyectos pilotos. A continuación, se analizará la experiencia de dos proyectos pilotos sobre mediación penal y acuerdos reparatorios celebrados entre el Ministerio Público y centros externos de mediación penal:

4.4.1. Proyecto de Mediación Penal del Centro de Atención Integral de Víctimas de Delitos Violentos (CAVID) de la Corporación de Asistencia Judicial del Bío-Bío, en la ciudad de Temuco. ${ }^{103}$

El proyecto parte como una iniciativa conjunta entre el Ministerio Público, a través de su División Nacional de Atención a Víctimas y Testigos y la Unidad Regional de Atención a Víctimas y Testigos de la Araucanía, por un lado, y del CAVID y Centro de Mediación de la ciudad de Temuco, pertenecientes a la CAJ de Bío-Bío, por el otro.

Los objetivos Generales del proyecto eran:

- Privilegiar la implementación de términos judicializados y con solución del conflicto jurídico versus los no judicializados. ${ }^{104}$

- Mejorar la "calidad" de los términos del caso, a través de acuerdos reparatorios, en función de las expectativas de la víctima.

Por su parte, entre los objetivos específicos del proyecto, destacan:

- Generar un procedimiento estándar de abordaje de los acuerdos reparatorios.

\footnotetext{
${ }^{103}$ Esta descripción del programa se basa en un Informe elaborado en Octubre de 2007 por la Coordinadora del proyecto, Sra. Mónica Muhaded, Abogada Coordinadora del CAIVD, quien gentilmente lo facilitó a esta autora para su inclusión en el presente artículo.

${ }^{104}$ Las salidas o términos judicializadas, en los sistemas estadísticos del Ministerio Público, representan una mejor forma de término de la causa que las salidas facultativas del fiscal, tales como el archivo provisional y el principio de oportunidad (que representan formas de desestimación del caso sin que exista una condición a cumplir por parte del imputado y/o una reparación a la víctima).
} 
DÍAZ, ALEJANDRA. "La experiencia de la mediación penal en Chile".

- Radicar los procesos de RAC conducentes a la celebración de acuerdos reparatorios y, eventualmente, suspensiones condicionales del procedimiento, en órganos externos especializados y particularmente competentes en mediación penal, reduciendo la posibilidad de "fracaso" de los acuerdos.

A partir de Marzo del año 2006 hasta Agosto, se propuso como Proyecto Piloto, periodo en que no se registraron derivaciones por parte de las instituciones participantes, extendiendo dicho plazo hasta Septiembre del 2007.

El modelo utilizado se inscribe expresamente en el marco de la justicia restaurativa, reconociendo entre sus orígenes el movimiento VORP en USA y Canadá, el movimiento por los derechos de las víctimas, y el movimiento de RAC y los derechos de la comunidad, y reconociendo a las diversas tradiciones teóricas y prácticas sobre justicia restaurativa, tales como la Cristiana, la Comunitaria, el Abolicionismo y la Resolución Institucional de los Conflictos planteada por Wesley Cragg.

El modelo de Mediación Penal adoptado por el piloto se basa en los estudios y experiencias que se han realizado en el país, en aportes tomados de la experiencia española y argentina, y específicamente, en el trabajo con víctimas y en mediación desarrollado en la Región de La Araucanía (Novena región).

Para estos efectos, el proyecto concibe a la Mediación como:

"Un sistema de negociación asistida, mediante la cual las partes involucradas en un conflicto intentan resolverlo por sí mismas con la ayuda de un tercero imparcial, que actúa como conductor de la sesión, ayudando a las personas que participan en la mediación a encontrar una solución que sea satisfactoria para ambas partes" 105

En cuanto a la experiencia del Centro que sirve de contexto al modelo, el centro llevaba cinco años trabajando en mediación con resultados satisfactorios, en el sentido de haber hecho posible desjudicializar conflictos que antiguamente solo eran transables en Tribunales, como los de familia, y entregar a los usuarios la posibilidad de enfrentar situaciones difíciles, dentro de un marco más afable, aminorando el impacto y los costos emocionales del conflicto, aumentando así la satisfacción de los usuarios con el servicio.

Por otra parte, los Centros de Atención Integral a Víctimas de Delitos Violentos llevaban ya casi cuatro años de existencia, y su experiencia los llevó a querer mirar desde otra perspectiva el tema de la atención y reparación a la víctima. Esta nueva perspectiva les indicaba que además de un modelo sistémico, jurídico-psicosocial, se hacía necesario presentar una alternativa de atención a las víctimas en que, dependiendo del caso, el concepto de reparación pudiera involucrar una participación activa de víctima y ofensor.

${ }^{105}$ Toman dicho concepto de la siguiente fuente: “Intermediación”, en: http://www.intermediación.com 
Polít. crim. Vol. 5, No 9 (Julio 2010), Art. 1, pp. 1-68.

[http://www.politicacriminal.cl/Vol_05/n_09/Vol5N9A1.pdf]

De esta forma, la mediación surgió para ambos centros como una alternativa a la judicialización, que brindaba la oportunidad al infractor de solucionar el conflicto surgido entre él y la comunidad y de resolver directamente los problemas generados con la víctima a través de un proceso en que lo fundamental es la participación activa y voluntaria de las partes. Ello permitiría atender a las necesidades de los directamente involucrados, logrando la pacificación del conflicto penal, y evitando nuevos conflictos.

Se valoraba también el efecto preventivo de reincidencia en el ofensor, logrado a través de la responsabilización y auto-aprendizaje; la posibilidad para la víctima de obtener reparación tanto material como inmaterial y simbólica, y; la descompresión de la carga de trabajo de los Tribunales y del Ministerio Público.

Finalmente, se valoraba el que esta nueva forma de enfrentar los conflictos contribuyera a que la ciudadanía tuviera una mejor percepción acerca del sistema de justicia.

\section{PROCEDIMIENTO}

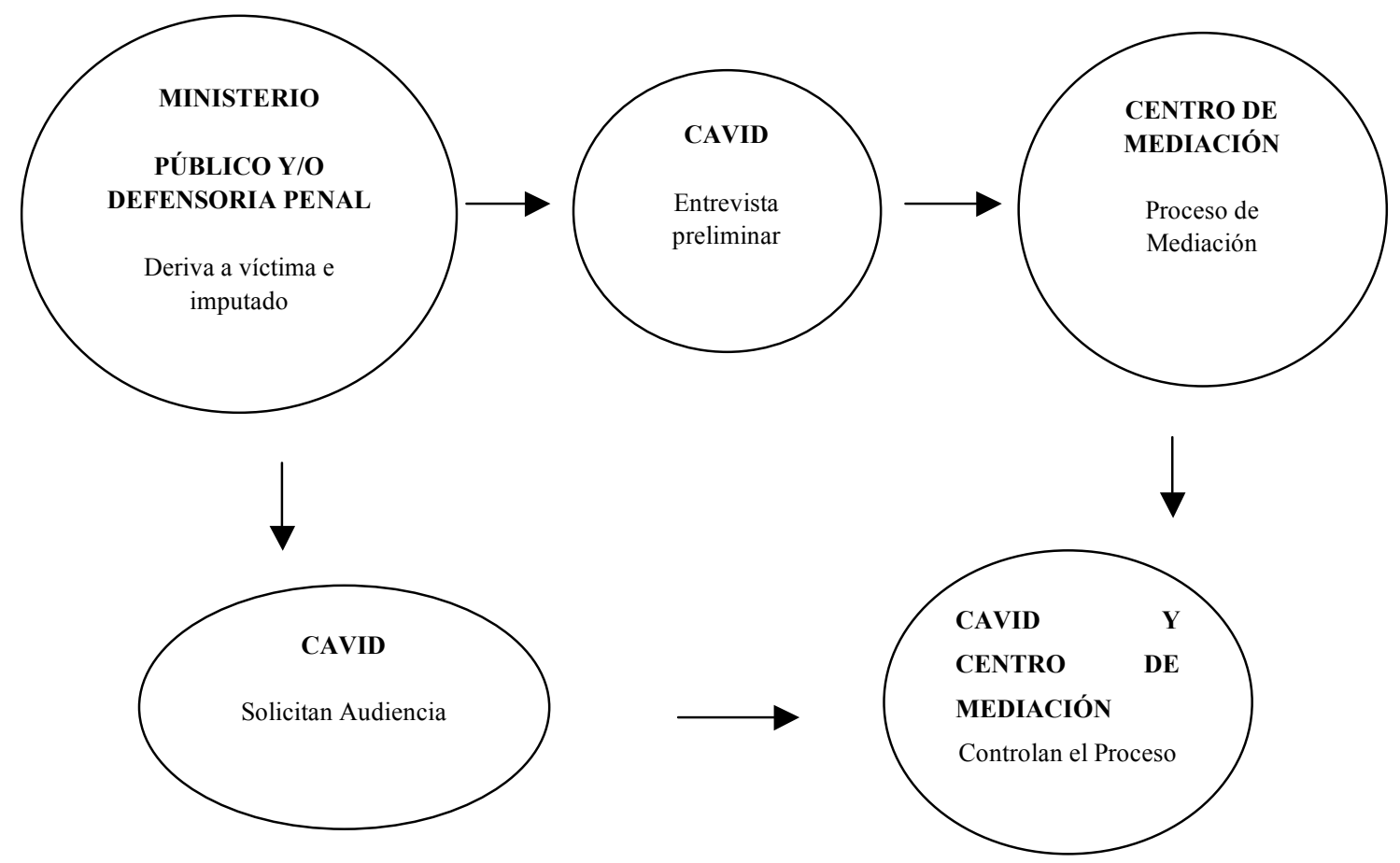

El Ministerio Público y/o Defensoría Penal Pública, derivan el caso al Centro de Atención Integral a Víctimas de la CAJ (cabe la posibilidad de que la derivación sea solicitada en audiencia por alguna de las Instituciones en referencia).

El caso es recepcionado por el CAVID, quien cita a víctima e imputado por separado a una entrevista preliminar. 
DÍAZ, ALEJANDRA. "La experiencia de la mediación penal en Chile".

Se realiza por separado la entrevista preliminar que tendrá por objetivo: Acoger a ambas partes, evaluar las reales posibilidades de llegar al acuerdo, verificar el consentimiento libre y espontáneo de la víctima para dicho acuerdo, y dar a conocer los efectos jurídicos que produce dicho acuerdo.

El Centro de mediación o CAVID de la CAJ, realiza a través de sesiones conjuntas o individuales el proceso de mediación o negociación penal asistida, con el objeto de fijar el contenido de los acuerdos.

Si se ha llegado a acuerdo, se solicita ante el Tribunal de Garantía la celebración de una audiencia para la aprobación judicial de dicho acuerdo.

Si no se ha arribado a acuerdo, se informa dicha situación al Ministerio Público y a la Defensoría Penal Pública.

a) Modificaciones incorporadas al Modelo original.

Las modificaciones realizadas al modelo original resultaron de las reuniones efectuadas con la Defensoría Penal Pública y el Ministerio Público, destinadas a optimizar las derivaciones y la atención de los usuarios en el menor tiempo posible. Para ello, tanto el Centro de Atención a Víctimas de Delitos violentos como el Centro de Mediación, establecieron horarios de atención acordes a las necesidades y, por otra parte, se acordó el número de casos con capacidad de ingresar y atender, correspondiendo éste a un máximo de 30 casos mensuales. Debido al bajo porcentaje de derivaciones, las modificaciones efectuadas no pudieron ser evaluadas en su real magnitud.

\section{b) Estadisticas.}

Total de Casos derivados: 33

Casos concluidos con acuerdo: 10

Evaluación de las partes frente a la experiencia:

- Se realizaron 11 encuestas de satisfacción

- De las cuales 8 llegaron a acuerdo y 3 no lo lograron, los resultados obtenidos de la encuesta diseñada son los siguientes: 
Polit. crim. Vol. 5, № 9 (Julio 2010), Art. 1, pp. 1-68.

[http://www.politicacriminal.cl/Vol_05/n_09/Vol5N9A1.pdf]

\begin{tabular}{|c|l|l|l|l|l|}
\hline PREGUNTAS & $\begin{array}{l}\text { Muy de } \\
\text { acuerdo }\end{array}$ & $\begin{array}{l}\text { De } \\
\text { acuerdo }\end{array}$ & No sabe & $\begin{array}{l}\text { En } \\
\text { desacuerd } \\
\text { o }\end{array}$ & $\begin{array}{l}\text { Muy en } \\
\text { desacuerd } \\
\text { o }\end{array}$ \\
\hline $\begin{array}{c}\text { En la primera entrevista, me explicaron claramente } \\
\text { de lo que se trataba el proceso de mediación, y los efectos } \\
\text { jurídicos de la misma. }\end{array}$ & $64 \%$ & $36 \%$ & $0 \%$ & $0 \%$ & $0 \%$ \\
\hline $\begin{array}{c}\text { En la primera entrevista, me sentí acogido(a) y } \\
\text { escuchado(a). }\end{array}$ & $46 \%$ & $27 \%$ & $0 \%$ & $18 \%$ & $9 \%$ \\
\hline $\begin{array}{c}\text { Durante el proceso de mediación, la atención fue } \\
\text { expedita, cumpliéndose los días y horas de las citaciones. }\end{array}$ & $82 \%$ & $9 \%$ & $0 \%$ & $0 \%$ & $9 \%$ \\
\hline $\begin{array}{c}\text { Durante la mediación los profesionales me } \\
\text { atendieron con respeto, y con actitud imparcial hacia ambas } \\
\text { partes. }\end{array}$ & $64 \%$ & $27 \%$ & $0 \%$ & $0 \%$ & $9 \%$ \\
\hline $\begin{array}{c}* \text { En el momento de analizar y aprobar el } \\
\text { acuerdo, me sentí libre para dar mi opinión. }\end{array}$ & $25 \%$ & $50 \%$ & $0 \%$ & $50 \%$ \\
\hline $\begin{array}{c}\text { En el momento de firmar el acuerdo, estaba } \\
\text { informado de mis derechos, y los había comprendido } \\
\text { totalmente. }\end{array}$ & $50 \%$ & $50 \%$ & $0 \%$ & $0 \%$ \\
\hline $\begin{array}{c}* \text { Creo que el proceso de mediación me entrego una } \\
\text { buena y rápida solución a mi problema }\end{array}$ & $37 \%$ & $63 \%$ & $0 \%$ & $0 \%$ \\
\hline $\begin{array}{c}\text { Si se presentara un nuevo problema, consideraría la } \\
\text { mediación una buena alternativa de solución. }\end{array}$ & $73 \%$ & $27 \%$ & $0 \%$ & $0 \%$ \\
\hline
\end{tabular}

Si bien estos datos no permiten hacer demasiadas inferencias debido a lo pequeño de las cifras, sí resulta interesante destacar algunos elementos que pueden servir de "luces de alerta" para el programa, como por ejemplo, el alto porcentaje que no se sintió libre de dar su opinión, considerando, sobre todo, que uno de los principios básicos de estos procesos son la posibilidad que entregan a las partes de participar activamente en los mismos, así como el elemento de voluntariedad. Por otro lado, destaca la buena aprobación del programa y del proceso, y que el 100\% volvería a considerar la mediación como una buena alternativa de solución frente a futuros problemas (entre el grupo de los "muy de acuerdo" y los “de acuerdo").

\subsubsection{Proyecto de Mediación Penal Fiscalía Centro Norte-Universidad Diego Portales.}

Este proyecto surge, al igual que el anterior y más o menos en la misma época, como una iniciativa conjunta entre el Ministerio Público, a través de su División Nacional de Atención a Víctimas y Testigos y la Unidad Regional de Atención a Víctimas y Testigos de la Fiscalía Regional Metropolitana Centro Norte, por un lado, y la Facultad de Derecho de la Universidad Diego Portales (en adelante, UDP), por la otra. Se enmarca, teóricamente, en el modelo de justicia restaurativa.

\footnotetext{
${ }^{*}$ Los porcentajes obtenidos en estas preguntas son los de las 8 personas que llegaron a acuerdo durante el proceso de mediación.
} 
DÍAZ, ALEJANDRA. "La experiencia de la mediación penal en Chile".

El piloto se desarrolló entre noviembre de 2006 y abril de 2007, abarcando delitos cometidos por infractores adultos, que pudieran resolverse mediante acuerdos reparatorios. Las mediaciones se llevaron adelante en la Facultad de Derecho de la UDP, y consistieron en mediación penal directa.

El proyecto recibió 14 casos. Hubo 8 casos en que se hizo algún tipo de mediación (reuniones preliminares con la víctima o el imputado) y dos casos terminaron en acuerdo luego de una mediación directa.

\subsubsection{Otros proyectos e iniciativas.}

Finalmente, han existido otros intentos por implementar proyectos de mediación penal en Chile, como el iniciado por el Instituto Carlos Casanueva y su red de centros de mediación, en conjunto con la Fiscalía Regional Metropolitana Sur. ${ }^{106}$ Esta red de centros, si bien tenían una especialización en mediación familiar, se capacitaron en mediación penal a fin de poder recibir casos desde la Fiscalía. Si bien las derivaciones de casos realizadas fueron pocas, esta iniciativa significó la creación de una Mesa de Trabajo de Implementación de la Mediación Penal entre el Instituto y algunos fiscales de la Fiscalía Metropolitana Sur comprometidos con el tema, culminando en la elaboración de un Manual de Procedimientos de Mediación Penal ${ }^{107}$ que establece, entre otros aspectos, un procedimiento estándar de derivación de casos y ejecución de la mediación penal. Algunas de las lecciones aprendidas a raíz de este proyecto, se refieren a las posibles razones por las cuales no pudo prolongarse en el tiempo, destacando las siguientes: ${ }^{108}$

a) Falta de financiamiento de los centros, los cuales operaban con profesionales mediadores y no con voluntarios,

b) Procedimientos de derivación de casos entre fiscales y mediadores no implementados adecuadamente,

c) La mediación penal puede implicar para el fiscal que el caso demore más tiempo en cerrarse, comparado con los tiempos de tramitación de un Acuerdo Reparatorio sin mediación, el cual puede concluirse mediante alguna otra técnica de RAC aplicada por el fiscal.

\footnotetext{
${ }^{106}$ Ver nota de prensa sobre el proyecto, en Diario La Nación, 4 de julio de 2005: http://www.lanacion.cl [visitado el 01.04. 2009].

${ }^{107}$ Ver en:

http://www.justiciarestaurativa.org/aroundla/chile/manual/view?searchterm=Manual\%20Mediacion $\% 20 \mathrm{Penal}$ [visitado el 31.03.2009]

${ }^{108}$ Conversación personal con Mario Vargas, Presidente Red de Centros de Mediación y Director del Instituto de Mediación y Arbitraje de Chile, Marzo de 2009.
} 
Polít. crim. Vol. 5, No 9 (Julio 2010), Art. 1, pp. 1-68.

[http://www.politicacriminal.cl/Vol_05/n_09/Vol5N9A1.pdf]

d) Distancia entre los centros de mediación y el lugar de residencia de los usuarios, los cuales vivían por lo general en la zona sur de Santiago, en tanto que los centros estaban ubicados en la zona centro de la capital.

Por su parte, la Corporación de Asistencia Judicial de Valparaíso ha comenzado a explorar en el área de la mediación penal, al igual que el Centro de Mediación Iquique perteneciente a la CAJ de Tarapacá y Antofagasta. ${ }^{109}$

Asimismo, la Corporación de Asistencia Judicial de la Región Metropolitana ha comenzado desde el año 2008 ha recibir regularmente derivaciones de casos por parte de los fiscales de las Fiscalías Regionales Sur, Centro-Norte y Oriente. En la Fiscalía Regional Centro Norte la derivación comenzó desde la Fiscalía Territorial A, con el levantamiento de casos por su Unidad de Tramitación de Casos Menos Complejos, de acuerdo a los criterios de selección de casos acordados con profesionales de la CAJ. A su vez, existe la posibilidad que los fiscales levanten casos en el transcurso de la investigación (especialmente en casos de cuasidelitos de lesiones).

A continuación se señalan algunos números respecto de la experiencia con la Fiscalía Centro Norte: ${ }^{10}$

\section{Cuadro $\mathrm{N}^{\circ} 1$}

Resultados del año 2008

\begin{tabular}{|l|r|}
\hline TOTAL DE CASOS DERIVADOS & \\
TOTAL DE CASOS SIN & 108 \\
MEDIACIÓN & \\
TOTAL CASOS CON MEDIACIÓN & 63 \\
\hline TOTAL CASOS CON ACUERDO & 45 \\
\hline TOTAL CASOS SIN ACUERDO & 37 \\
\hline
\end{tabular}

No se llegó a mediación en un 59\% de los casos (63).

Se mediaron un $42 \%$ (45) de los cuales se llegó a acuerdo en un $82 \%$ (37) y sin acuerdo en un $15 \%(8)$.

El tipo de delitos derivados fueron básicamente amenazas, cuasidelitos de lesiones, daños simples, disensiones domésticas, hurto simple, lesiones y otros hechos.

\footnotetext{
${ }^{109}$ El presente trabajo no comprende un catastro exhaustivo de centros de mediación que realicen mediación penal, sino que sólo se contienen los que se consideran más conocidos.

${ }_{110}$ Datos proporcionados gentilmente por Iván Navarro, coordinador (s) del Centro de Mediación de la CAJ Región Metropolitana.
} 
DÍAZ, ALEJANDRA. "La experiencia de la mediación penal en Chile".

En el mes de mayo de 2009, se integró al proyecto piloto la Fiscalía de Delitos Económicos, con el fin de derivar delitos de apropiación indebida.

\section{Cuadro $\mathrm{N}^{\circ} 2$}

Resultados del año 2009

\begin{tabular}{l:}
\hline TOTAL DE CASOS DERIVADOS \\
TOTAL DE CASOS SIN \\
MEDIACIÓN \\
TOTAL CASOS CON MEDIACIÓN \\
TOTAL CASOS CON ACUERDO \\
TOTAL CASOS SIN ACUERDO \\
\hline
\end{tabular}

Al 31 de Junio de 2009, se habían derivado 75 casos.

No se llegó a mediación en un $60 \%$ de los casos (45).

Se mediaron un $40 \%$ (30) de los cuales se llegó a acuerdo en un $83 \%$ (25) y sin acuerdo en un $17 \%(5)$.

Habiendo analizado la experiencia de la mediación penal con ofensores adultos, la siguiente sección se aboca a un breve análisis de la situación de la mediación penal con jóvenes ofensores en Chile.

\section{La Mediación Penal Juvenil.}

En Chile, la nueva Ley de Responsabilidad Penal Juvenil No 20.084, que comenzó a regir el 8 de junio de 2007, y que estableció un nuevo sistema de justicia penal para jóvenes cuyas edades fluctúen entre los 14 y 17 años cumplidos, cambió el antiguo sistema tutelar de menores hacia un sistema de responsabilidad o de justicia, basado en la Convención de los Derechos del Niño. Este nuevo sistema, en materia de procedimiento, es muy similar al de adultos, funcionando con la presencia de fiscales, defensores penales públicos, jueces de garantía y tribunales orales en lo penal y la existencia de juicio público, oral y contradictorio, entre otros aspectos. En él, los jóvenes gozan de los mismos derechos y garantías que los imputados adultos, más algunos derechos y garantías especiales establecidos en razón de su menor edad, madurez y culpabilidad, y son responsables de los delitos que cometan (eliminándose la tan criticada institución del "discernimiento", que determinaba si un joven sería o no juzgado en el sistema penal de adultos en base a su capacidad o no para discernir lo correcto de su actuar).

En la nueva Ley de Responsabilidad Penal Juvenil (en adelante, LRPA), existen numerosas oportunidades para aplicar la justicia restaurativa y la mediación penal, si bien aún es 
Polít. crim. Vol. 5, No 9 (Julio 2010), Art. 1, pp. 1-68.

[http://www.politicacriminal.cl/Vol_05/n_09/Vol5N9A1.pdf]

necesario ampliarlas, pues al momento de discutirse y aprobarse esta ley, no se dio un debate amplio en el Congreso acerca de la posibilidad de incorporar la justicia restaurativa como una respuesta central a la delincuencia juvenil. Las oportunidades para implementar la mediación penal y justicia restaurativa se dan principalmente en el marco de los acuerdos reparatorios, la suspensión condicional del procedimiento y las nuevas sanciones de contenido reparatorio que establece la ley. Sin embargo, es lamentable que esta ley no haya innovado demasiado en este aspecto, pues en el proyecto del Ejecutivo enviado al Congreso ( 2 de agosto de 2002) y en las versiones previas de la ley, sí se establecían los componentes restaurativos de manera más amplia.

El proyecto de ley del Ejecutivo establecía la procedencia de los acuerdos reparatorios en los procesos penales juveniles de manera mucho más amplia que en el caso de los adultos, pues no se establecían las limitantes de los incisos segundo y tercero del artículo 241 CPP, relativas al tipo de delito. Además, se eliminaba la facultad del juez de rechazar la aprobación del acuerdo reparatorio en base a la existencia de un interés público prevalente en la continuación de la persecución penal. Durante la tramitación legislativa, la regulación de esta institución sufrió varios cambios, planteándose incluso la posibilidad de incorporar mecanismos de mediación acordes con las tendencias restaurativas comparadas. Asimismo, se alcanzó a establecer como exigencia que tanto el Ministerio Público como la Defensoría contaran con equipos especializados destinados a mediar entre la víctima y el imputado. Sin embargo, en el tercer trámite constitucional, la Comisión Mixta finalmente decidió eliminar la alusión a dicha salida, toda vez que no le resultó satisfactoria la amplitud de su regulación, estimando que la misma podía desnaturalizarse en el evento que se utilizara como un mero mecanismo de compensación económica de quienes disponían de recursos. 111112 Cabe señalar, que la Defensoría Penal Pública planteó, ya en el año 2004, mientras se discutía la ley de responsabilidad penal juvenil en el Senado, que era necesario potenciar la justicia restaurativa con los adolescentes infractores, que es donde más se ha desarrollado a nivel internacional, y con un mayor número de casos. Sin embargo, no se hizo una mención expresa a esta forma de justicia, ni a la mediación penal, en la ley que fue finalmente aprobada en el Congreso. Tampoco se amplió el marco de procedencia de los acuerdos reparatorios. No obstante ello, es preciso señalar que tratándose de la suspensión condicional del procedimiento, por la rebaja de pena que opera para los adolescentes en relación a los adultos (Art 21 LRPA), y considerando que el límite de procedencia de la SCP consiste en delitos cuya pena concreta no supere los tres años de privación de libertad, esta salida alternativa procede respecto de una gama más amplia que para los adultos. ${ }^{113}$

En el nuevo sistema de justicia penal juvenil, se puede implementar la justicia restaurativa y la mediación penal no sólo en el ámbito de las salidas alternativas y principio de oportunidad, sino que en una fase más avanzada del procedimiento, cuando ya ha habido juicio y condena, a través de las penas de reparación a la víctima y los servicios en

\footnotetext{
${ }^{111}$ MORALES, cit. nota $\mathrm{n}^{\mathrm{0}}$ 70, p. 162.

${ }^{112}$ Vid. Informe de la Comisión Mixta en el Tercer Trámite Constitucional, pp.12.

113 COUSO, J., "La política criminal para adolescentes y la Ley 20.084", Documento de Trabajo, Unidad de Defensa Penal Juvenil, Defensoría Penal Pública, Santiago de Chile, 2008.
} 
DÍAZ, ALEJANDRA. "La experiencia de la mediación penal en Chile".

beneficio de la comunidad. La LRPA establece en su Art. 11 la sanción de Servicios en Beneficio de la Comunidad, señalando:

"La sanción de prestación de servicios en beneficio de la comunidad consiste en la realización de actividades no remuneradas a favor de la colectividad o en beneficio de personas en situación de precariedad. La prestación de servicios en beneficio de la comunidad no podrá exceder en ningún caso de cuatro horas diarias y deberá ser compatible con la actividad educacional o laboral que el adolescente realice. La sanción tendrá una extensión mínima de 30 horas y máxima de 120. La imposición de esta sanción requerirá del acuerdo del condenado, debiendo, en su caso, ser sustituida por una sanción superior, no privativa de libertad". 114

Por su parte, en el Artículo 10 se establece la sanción de Reparación del Daño a la víctima, reparación que puede consistir en el pago de una suma de dinero, la restitución o reposición de la cosa, o un servicio no remunerado a favor de la víctima. En este último caso, se requiere la aceptación previa del condenado y de la víctima. La ley no menciona expresamente la posibilidad de realizar procesos de mediación penal en estos casos.

Esta es la primera vez en Chile que se establecen penas de contenido reparatorio como sanciones de aplicación general. No existe una regulación similar en el caso de adultos.

Estas penas pueden ser aplicadas por el juez respecto de todos aquellos delitos cuyos marcos penales se ubiquen en los siguientes tramos de penalidad: ${ }^{115}$ en el caso de la pena de reparación, ésta se puede imponer respecto de los delitos cuyo marco penal fluctúe entre 1 a 540 días de privación de libertad (en la práctica, se tratará básicamente de delitos de menor y mediana gravedad, como los hurtos simples, las amenazas, los daños a la propiedad, el robo en lugar no habitado, el robo en bienes nacionales de uso público - típicamente el robo de vehículos-, el robo por sorpresa y las lesiones leves y de cierta gravedad, entre otros). Respecto de los Servicios en Beneficio de la Comunidad (en adelante, SBC), la ley los establece para delitos cuya pena no sea superior a 3 años de privación de libertad, de manera que los delitos para los que puede establecerse serán faltas, delitos menores y delitos de mediana gravedad, que abarcan prácticamente los mismos señalados para la sanción de reparación, más algunos otros delitos de mayor gravedad, como algunos delitos sexuales. Pero incluso, considerando el posible juego de circunstancias atenuantes de responsabilidad penal para el caso concreto (como la irreprochable conducta anterior), podrían eventualmente recibir una sanción de Servicios en Beneficio de la Comunidad delitos graves tales como el robo con violencia e intimidación.

\footnotetext{
${ }^{114}$ Esta sanción será una libertad asistida ordinaria o especial, cuya diferencia es que la especial es de mayor intensidad que la libertad asistida ordinaria.

${ }^{115}$ La ley de responsabilidad penal juvenil establece un mecanismo de determinación de penas consistente en establecer el marco penal que corresponde al delito a partir de la pena asignada al mismo en el Código Penal, para luego ordenar la rebaja de pena en un grado para los adolescentes, y a partir de ese marco de extensión medido en días de privación de libertad, se establece una gama de penas de distinta naturaleza que las de adultos, dentro de las cuales el juez puede elegir basándose en ciertos criterios establecidos por el legislador, y siendo las más comunes las penas no privativas de libertad.
} 
Polít. crim. Vol. 5, No 9 (Julio 2010), Art. 1, pp. 1-68.

[http://www.politicacriminal.cl/Vol_05/n_09/Vol5N9A1.pdf]

La sanción de reparación, por su naturaleza, es la que admite con mayor propiedad la inclusión de procesos de mediación penal y justicia restaurativa, en tanto que los servicios en beneficio de la comunidad, permitirían incorporar sólo algunas nociones y/o principios de justicia restaurativa en su implementación. ${ }^{116}$

Previo al inicio de la LRPA, y como una manera de preparar su puesta en marcha, se implementaron en Chile Programas de Medidas Reparatorias que incluían la reparación a la víctima y el servicio en beneficio de la comunidad. La idea era testear estos modelos e introducir correcciones a los mismos, de manera de implementarlos posteriormente en el marco de las salidas alternativas y las sanciones de contenido reparatorio. Estos proyectos fueron impulsados por el Servicio Nacional de Menores (en adelante, SENAME), ${ }^{117}$ a través de organizaciones privadas sin fines de lucro, y comenzaron a operar desde el año 2003 en diversas regiones del país. Específicamente, la línea de reparación del daño contempló el desarrollo de procesos de mediación penal entre jóvenes infractores y sus víctimas. Estos proyectos implicaron la acumulación de una valiosa experiencia en el campo de la mediación penal con jóvenes ofensores. Entre las lecciones aprendidas, se encuentran: ${ }^{118}$

- La importancia de la etapa de "pre-mediación", consistente en la realización de entrevistas individuales previas con las partes.

- La importancia de involucrar a los padres del joven ofensor en el proceso, de manera de comprometerlos con el mismo y que brinden su apoyo al joven en el cumplimiento de sus compromisos,

- La importancia de identificar tempranamente factores que puedan obstaculizar el éxito del proceso, tales como daño psico-social del joven o consumo problemático de drogas, y adoptar estrategias adecuadas al caso, que pueden ir desde cambiar la línea de intervención (a un servicio comunitario, por ejemplo) hasta brindar apoyo psico-social al joven.

- En relación a la víctima, la importancia de comunicarse directamente con ésta evitando intermediarios que modifiquen la información de los objetivos y forma del trabajo del programa. Asimismo, velar en todo momento por un proceso justo y porque los acuerdos se cumplan.

116 DÍAZ, Alejandra, "Los servicios en beneficio de la comunidad y la prevención de la reincidencia: enseñanzas de las experiencias comparadas", Ponencia presentada en Seminario Justicia Juvenil: una Visión Restaurativa, Santiago de Chile, 17 y 18 de Noviembre de 2008, en: http://www.restorativejustice.org [visitado el 01.04.2009].

${ }^{117}$ Servicio dependiente del Ministerio de Justicia.

${ }^{118}$ COUSO, J.; LÓPEZ, C., "Sistematización y proyección de experiencias de trabajo en medio libre con adolescentes infractores de ley", Informe para SENAME, encargado al Programa de Derechos del Niño de la Universidad Diego Portales, Octubre de 2005. 
DÍAZ, ALEJANDRA. "La experiencia de la mediación penal en Chile".

- Finalmente, en relación a los acuerdos propiamente tales, se releva la importancia de que éstos consideren los intereses y demandas de las víctimas, que consideren las posibilidades o capacidades reparatorias del joven y no atenten contra su dignidad, que estén relacionados con el daño causado (principio de proporcionalidad), y que tengan, por último, un efecto responsabilizador en el joven.

El Servicio Nacional de Menores administra las sanciones no privativas de libertad de los adolescentes, así como los centros privativos de libertad. Para las sanciones de reparación del daño y SBC, el SENAME ha establecido programas específicos, ejecutados por organizaciones sin fines de lucro de la sociedad civil, llamadas "instituciones colaboradoras" (del SENAME), las cuales debieron postular a procesos de licitación pública para adjudicarse los casos de jóvenes condenados en una determinada jurisdicción. Varias de estas instituciones fueron las que participaron previamente en los Programas Pilotos de Medidas Reparatorias descritos previamente. En su forma de trabajo, dichos programas deben regirse por las Orientaciones Técnicas que emite SENAME, de manera que tanto los principios como los procedimientos que apliquen estarán bastante determinados por el nivel central. El SENAME ha emitido Orientaciones Técnicas específicas para cada una de estas sanciones. En las Orientaciones Técnicas para la Sanción de Reparación del Daño, ${ }^{119}$ se señala a la mediación penal como la metodología principal de intervención, señalando que ello permitirá que la reparación del daño cumpla con los fines generales de las sanciones juveniles, señalados en el Art. 20 de la LRPA y consistentes en "hacer efectiva la responsabilidad de los adolescentes por los hechos delictivos que cometan, de tal manera que la sanción forme parte de una intervención socioeducativa amplia y orientada a la plena integración social".

Las Orientaciones Técnicas inscriben a la mediación penal juvenil dentro de un marco que persigue esencialmente fines educativos y responsabilizadores del joven, sin perjuicio de incorporar también otros fines que SENAME establece para todas sus sanciones. ${ }^{120}$

Además, las OT incorporan en la mediación penal juvenil expresamente algunos elementos del enfoque restaurativo, tomando en consideración a la Resolución de las Naciones Unidas (ECOSOC, 2002) y al Handbook on Restorative Justice Programmes de las Naciones Unidas (2006).

En cuanto a los modelos de mediación a utilizar, las OT plantean que éstos son variados, pudiendo adaptarse a las características de cada caso, y pudiendo utilizarse la mediación penal directa, la indirecta, así como aplicarse el modelo Tradicional - Lineal de Harvard, el Modelo Transformativo de Bush y Folger, y el Modelo Circular-Narrativo de Sara Cobb.

\footnotetext{
${ }^{119}$ Resolución Exenta N 81, de la Directora del Servicio Nacional de Menores, de 2 de Marzo de 2007.

${ }^{120}$ Ellas son: la Reparación del joven, consistente en detectar situaciones de vulneración de derechos y ofrecer al joven la posibilidad de repararlos (por ejemplo, mediante ayuda terapéutica de carácter voluntaria para el joven), la Habilitación, entendida como el aprendizaje de habilidades sociales y de otro tipo, que en el caso específico de la mediación, consistirán, por ejemplo, en aprender a resolver conflictos, y la Integración Social, consistente en evitar los efectos estigmatizantes de la sanción y propender a la reintegración del joven en la comunidad.
} 
Polít. crim. Vol. 5, No 9 (Julio 2010), Art. 1, pp. 1-68.

[http://www.politicacriminal.cl/Vol_05/n_09/Vol5N9A1.pdf]

Finalmente, las OT describen las etapas del proceso de mediación penal, desde el ingreso del caso hasta su cierre, incluyendo el envío de informes de cumplimiento al tribunal.

Lamentablemente, no se han llevado a cabo procesos de mediación penal en lo que va del primer año de vigencia de la nueva ley y han sido escasísimas las sanciones de reparación dictadas por los tribunales, y las pocas que se han dictado, no han implicado la realización de un proceso de mediación penal en su base. Según las estadísticas del primer año de vigencia de la LRPA, sólo un $0,3 \%$ del total de sanciones decretadas por los jueces correspondió a reparación del daño. Comparativamente, la sanción de servicios en beneficio de la comunidad representó el $29,1 \%$ del total de sanciones decretadas, configurándose en una de las más importantes y utilizadas sanciones del sistema penal juvenil. $^{121}$

Es probable que una de las razones del escaso número de sanciones de reparación dictadas por los jueces se deba a que la LRPA no contempló plazos ni procedimientos especiales para la realización de procesos restaurativos, de manera que, una vez establecido el veredicto de culpabilidad, no se contempla un plazo o período especial para intentar, por ejemplo, una mediación penal cuyo resultado, de llegar las partes a un acuerdo, pudiera ser considerado por el juez en su sentencia. Tampoco se establecen mecanismos que permitan a los jueces saber cuál es el tipo de reparación que la víctima desea recibir. Sin estos antecedentes, es muy difícil que un juez decida imponer una pena de reparación, especialmente porque cuando la reparación no es monetaria sino que consiste en un trabajo a favor de la víctima, se requiere de su acuerdo y el del joven para poder decretarla. Asimismo, el hecho de que el juez carezca de un informe que le señale si el joven tiene o no capacidad para reparar económicamente a la víctima, puede ser una razón adicional que desincentive a los jueces para decretar esta sanción.

Todo esto ha redundado en que los programas de Medidas Reparatorias, que se capacitaron y prepararon en mediación penal previo al inicio de la nueva ley, no están hoy por hoy utilizando esas capacidades y habilidades adquiridas, y han debido abocarse fundamentalmente a intervenir en las sanciones de servicios en beneficio de la comunidad. Estos programas tampoco están abocados a desarrollar procesos de mediación penal juvenil en el marco de los Acuerdos Reparatorios, debido a que las autoridades han interpretado que no existiría una base legal clara para ello, y no se habría incorporado esta posibilidad en sus contratos.

\section{Reflexiones finales acerca de la justicia restaurativa y la mediación penal en Chile.}

Del análisis realizado en este artículo, se desprende que no ha existido en Chile una política pública expresa para incorporar a la mediación penal en los casos de adultos y, tratándose de jóvenes, se puede afirmar que ha habido un asomo de política pública en este sentido, la cual no ha sido ni firme ni clara al respecto. Desde la sociedad civil, ha habido intentos de incorporar a la mediación penal, pero ello ha resultado una tarea muy difícil, especialmente

\footnotetext{
${ }^{121}$ Informe Estadístico Primer Año de Vigencia de la nueva Ley de Responsabilidad Penal Adolescente (8 de junio 2007 - 7 de junio 2008), Departamento de Estudios, Defensoría Penal Pública.
} 
DÍAZ, ALEJANDRA. "La experiencia de la mediación penal en Chile".

en lo tocante a cómo interactuar de manera efectiva con, y motivar a, los actores del proceso penal para participar activamente de esta nueva forma de hacer justicia.

La pregunta que surge a raíz de esta constatación es: ¿Por qué la mediación penal no ha podido consolidarse en Chile, ampliando así a la justicia restaurativa?

Una de las posibles explicaciones a este fenómeno tiene que ver con la tradición política chilena, la estructura de su poder judicial, y su cultura legal:

Políticamente, Chile ha sido caracterizado como un Estado fuerte y centralizado, con una serie de rasgos autoritarios y la existencia de visiones centralizadas del poder en la sociedad, ${ }^{122}$ todo lo cual habría generado instituciones civiles y políticas también centralizadas. A su vez, su sistema judicial, directamente heredero del sistema Monárquico Español, experimentó pocos cambios durante el siglo XIX y XX, siendo un sistema bastante jerarquizado y basado, ideológicamente, en las ideas del constitucionalismo clásico y el movimiento codificador. Conforme a estas ideas, debe haber una separación estricta de poderes entre el Poder Ejecutivo, el Legislativo y el Judicial, y el juez es concebido prácticamente como un "esclavo" de la ley, que la aplica mecánicamente. Se ha señalado, también, que el Poder Judicial ha tenido a lo largo de su historia una cultura "corporativista", de defensa de sus intereses corporativos, bastante cerrada a las demandas y necesidades de la población civil. ${ }^{123}$ En el ámbito específico de la justicia criminal, previo a la reforma procesal penal, imperó un modelo inquisitivo, donde el juez era investigador, juzgador y sentenciador, y en donde se aplicaba el principio de legalidad estricto en la persecución de los delitos (si bien en la práctica, se aplicaba la oportunidad de manera informal). En el ámbito de la cultura legal chilena, ${ }^{124}$ las ideas del constitucionalismo clásico y del movimiento codificador han penetrado profundamente en la cultural legal profesional chilena, particularmente a través de la adopción del Código Civil en el siglo XIX, el cual continúa siendo aplicado hasta hoy, con algunas modificaciones. ${ }^{125}$ El Código

${ }^{122}$ KREBS, R., "Prólogo" en: GÓNGORA, M., Ensayo Histórico sobre la Noción de Estado en Chile en los Siglos XIX y XX, Colección Imagen de Chile, Santiago: Ed. Universitaria, 1998, pp. 45-58, p. 48.

${ }^{123}$ PEÑA, C., "Hacia una Caracterización del Ethos Legal: de Nuevo sobre la Cultura Jurídica" en: SQUELLA, A. (Ed.) Evolución de la Cultura Jurídica Chilena, Santiago: CPU, 1994, pp. 23-149.

${ }^{124}$ Squella, siguiendo a Lawrence Friedman, distingue entre dos tipos de culturas jurídicas o legales: la 'cultura jurídica externa' y la "cultura jurídica interna". La cultura jurídica externa la constituyen el conjunto de valores, actitudes y orientaciones que respecto del derecho, y más ampliamente del sistema legal, prevalecen entre la población de una sociedad determinada, es decir, entre aquellos individuos que sólo ocasionalmente, y en forma esporádica, llegan a tener contacto con la esfera de las instituciones y estructuras legales. Por su parte, la "cultura jurídica interna" estaría representada por el conjunto de valores, actitudes y orientaciones respecto del sistema legal que prevalecen entre aquellos individuos que de manera más directa, intensa y continuada tienen relación con el mismo sistema. Se trata, en suma, de la cultura jurídica de las profesiones jurídicas, tales como jueces, abogados, etc. (Squella, 1988a: 31). Squella advierte que existe una interrelación mutua entre la cultura jurídica y los elementos estructurales y sustantivos (normativos) del "sistema legal" (entendido según lo comprende Lawrence Friedman). El autor también se refiere a estas culturas como "cultura jurídica de los legos" y "cultura jurídica profesional", respectivamente.

${ }^{125}$ BASCUÑÁN, A., "El Concepto de Derecho y el Problema de las Fuentes del Derecho. Rol Expresivo e Instrumental del Derecho en la Sociedad", en: SQUELLA, A. (Ed.), La Cultura Jurídica Chilena, Santiago: CPU, 1992, pp. 55- 66. 
Polít. crim. Vol. 5, No 9 (Julio 2010), Art. 1, pp. 1-68.

[http://www.politicacriminal.cl/Vol_05/n_09/Vol5N9A1.pdf]

Civil contiene ideas relevantes en torno al rol de los jueces como sujetos que deben aplicar la ley mecánicamente; a la preeminencia de la ley por sobre otras fuentes del derecho, y al monopolio del legislador en la creación de las normas. De acuerdo a algunos autores, estas ideas podrían formar parte de la cultural legal profesional chilena. ${ }^{126}$

Estos rasgos relativos a la tradición política chilena, su sistema judicial y su cultura legal, permiten aseverar que la justicia restaurativa, con sus valores de participación democrática de los ciudadanos en la resolución de sus conflictos, y la creación de órdenes normativos locales, está en tensión con la tradición de las instituciones políticas y la cultural legal y judicial en Chile. Desde el poder judicial, se puede prever resistencia hacia esta forma de justicia, más aún en el ámbito de la justicia penal, que hasta hace muy poco se regía por el principio de legalidad estricta. Con la reforma procesal penal, entra un nuevo actor no considerado previamente en el escenario jurídico chileno, cual es el Fiscal, quien resulta ser clave para el éxito de los programas de mediación penal. Si bien el fiscal ejerce el principio de oportunidad en sentido amplio como una herramienta esencial en su gestión, no es menos cierto que forma parte de una institución autónoma, jerarquizada y centralizada, que tiene a su cargo la investigación de los delitos, dirigiendo para ello a las policías, y que representa el interés público en la persecución penal de los delitos. Esto permite pensar que el fiscal tendrá ciertas resistencias para delegar o transferir el poder sobre la resolución de un caso penal a las partes directamente afectadas por el mismo y/o a la comunidad, misma resistencia que podrían tener los jueces en delegar la decisión del caso a las partes, en la fase de sentencia (por ejemplo, en la sanción juvenil de reparación del daño).

Finalmente, la cultura legal chilena puede también ayudar a explicar la resistencia de los profesionales del derecho, especialmente los abogados, a incorporar estas formas de resolución de conflictos en la justicia penal.

No debe olvidarse que el Estado puede estar dispuesto a delegar su poder en los particulares tratándose de conflictos que desde siempre han tenido un fuerte componente privado, como las causas civiles, comerciales y en menor medida, familiares, pero que el sistema penal es la expresión misma del poder soberano del Estado, con lo cual, la descentralización del poder en este ámbito resulta mucho más compleja. ${ }^{127}$

Por otro lado, al entrar al Siglo XXI, Chile ha comenzado un intenso proceso de reformas de modernización del Estado y de la Justicia, el cual ha significado en este último ámbito, la incorporación decidida de mecanismos alternativos de resolución de conflictos. Estos cambios, y la difusión de la mediación en el ámbito civil y familiar, sin duda han ido familiarizando a los jueces y profesionales del derecho con esta nueva forma de hacer

\footnotetext{
${ }^{126}$ SQUELLA, La Cultura Jurídica Chilena, cit. nota $\mathrm{n}^{\circ} 125$. Debe advertirse, sin embargo, que esta cultura jurídica profesional no constituye un conjunto unánime de valores, actitudes y orientaciones, pues existen en Chile lo que podrían llamarse "subculturas jurídicas" que sustentan visiones distintas, y que tratarán a veces de abrirse paso para reemplazar todo lo que pueda ser o representar la cultura jurídica dominante (Squella, 1988b: 156).

${ }^{127}$ DÍAZ, "The Growth of an International Restorative Justice Movement", cit. nota no 93

${ }^{127}$ Ver Anexo 1 para una descripción de los entrevistados.
} 
DÍAZ, ALEJANDRA. "La experiencia de la mediación penal en Chile".

justicia, de manera que les resulte menos extraño aplicarla en el ámbito penal. También, estos desarrollos han ido creando un movimiento de resolución alternativa de conflictos en Chile, que sin duda ejercerá influencia e impactará en un mayor desarrollo de la mediación penal a futuro.

\subsection{Tal vez mediación penal aún no, pero justicia consensuada sí.}

Es preciso destacar, en todo caso, que si bien la mediación penal no ha prosperado realmente en Chile, la justicia consensuada en el ámbito penal, en el marco de las salidas alternativas al proceso penal, especialmente los acuerdos reparatorios, sí ha tenido aplicación, como se puede observar del análisis previo acerca de las técnicas de RAC utilizadas en las Fiscalías y Defensorías del país.

Este hecho es interesante, pues indica que sí existe una apertura y disposición de los actores de la reforma procesal penal a descentralizar el poder estatal en la resolución de conflictos, y lo que puede estar en entredicho es más bien la técnica o modelo a utilizar. ${ }^{128}$ Pareciera ser que la mediación penal directa, hasta ahora al menos, no ha sido la más apropiada para los fiscales y defensores como mecanismo para concluir acuerdos reparatorios y otros términos anticipados al proceso penal. Ello podría estar estrechamente vinculado a razones de gestión, dadas por el tiempo y esfuerzos que requiere poner en contacto a las partes y conducir procesos de mediación entre ellas, que llevarían a los actores del Ministerio Público y de la Defensoría Penal Pública a concluir acuerdos reparatorios a través de técnicas de negociación, conciliación y/o mediación penal indirecta. $\mathrm{O}$ bien, podría deberse a razones más "culturales" y/o estructurales relativas a los actores e instituciones involucradas.

El impacto de los acuerdos reparatorios en la solución de los casos penales no es menor. Por ejemplo, si se observan las estadísticas del Ministerio Público para los acuerdos reparatorios en el año 2004, se puede apreciar que los acuerdos reparatorios representaban el 1,48\% del total de Formas de Término, pero si se mide su impacto en relación al total de Salidas Jurídicas, este porcentaje sube al 7,7\%: ${ }^{129}$

\footnotetext{
${ }^{128}$ Circunstancias que, o bien matizan el análisis previo acerca de la cultura legal chilena, o bien indican que ésta podría estar transformándose.

${ }^{129}$ Las Salidas Jurídicas son aquellas que terminan con una resolución judicial. Así, entre las salidas jurídicas no se considera al archivo provisional del procedimiento, que es una salida o forma de término facultativa del fiscal aplicable a casos en los que no existen antecedentes suficientes de investigación, por ejemplo, cuando no hay imputado conocido, y que se aplica a un alto porcentaje de casos que ingresan al sistema. Resulta de esta forma, más "real" apreciar la relevancia de los AR respecto del universo de "salidas jurídicas", y no del total de Formas de Término, pues en aquél universo se encuentran los casos en los cuales sería posible celebrar un acuerdo reparatorio, en la medida que es impensable su procedencia cuando no hay imputado conocido.
} 
Polit. crim. Vol. 5, № 9 (Julio 2010), Art. 1, pp. 1-68.

[http://www.politicacriminal.cl/Vol_05/n_09/Vol5N9A1.pdf]
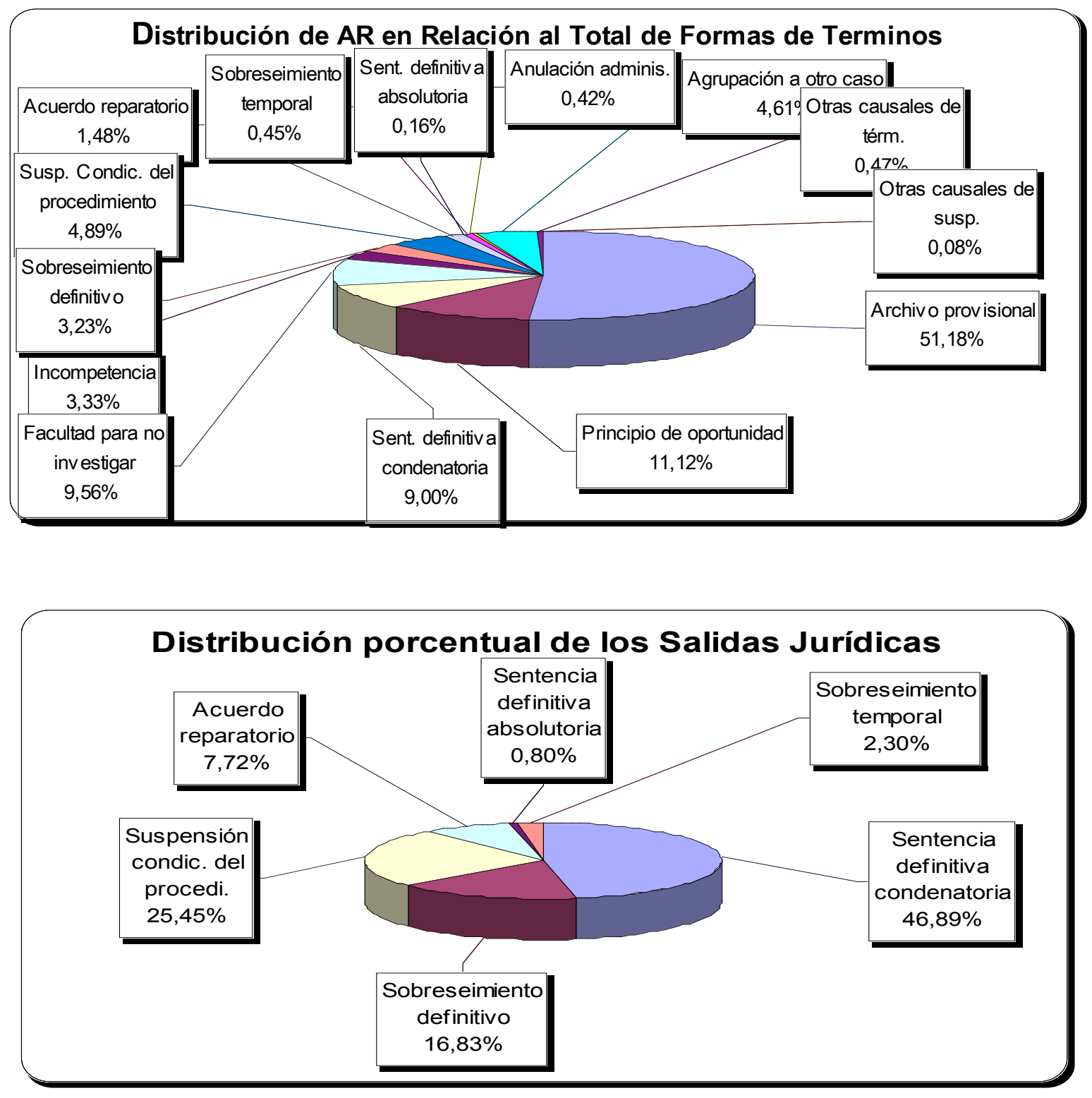

El porcentaje que los AR ocupan en el total de Salidas Jurídicas (7,7\% el año 2004), los sitúan como una forma de resolución de causas importantes del sistema procesal penal en su conjunto. Este porcentaje sube significativamente cuando se consideran los tipos de delitos susceptibles de AR (que son aquellos señalados en el Art. 241 del CPP), en lugar de la totalidad de delitos que ve el sistema: 
DÍAZ, ALEJANDRA. "La experiencia de la mediación penal en Chile".

Tipos de Delitos en los que el AR se aplica más frecuentemente y sus porcentajes, Período correspondiente al año 2004: ${ }^{130}$

\begin{tabular}{|l|c|c|}
\hline \multicolumn{1}{|c|}{ Delito } & $\begin{array}{c}\text { \% de AR en el Total de Formas } \\
\text { de Término }\end{array}$ & $\begin{array}{c}\text { \% de AR en el Total de Salidas } \\
\text { Jurídicas }\end{array}$ \\
\hline Hurtos & 1 & 5,7 \\
\hline Otros delitos c/propiedad & 3,7 & 19,6 \\
\hline Lesiones & 2,6 & 12,5 \\
\hline Delitos c/lib. e intimidad & 1,8 & 14,4 \\
\hline Delitos económicos & 3,6 & 20,5 \\
\hline
\end{tabular}

Como se puede apreciar en la tabla, en una selección de delitos en los cuales es procedente el AR, el lugar que éste ocupa como salida jurídica es bastante significativo, llegando incluso al $20,5 \%$ en los delitos económicos y al 19,6\% en los delitos contra la propiedad. Cabe señalar, sin embargo, que la proporción que los acuerdos reparatorios ocupan en el total de salidas alternativas ha tendido a disminuir desde que se implementó la Reforma Procesal Penal, según se muestra en Informe Estadístico de la Defensoría Penal Pública para el año 2007. ${ }^{131}$ Conforme a dicho informe, al inicio de la Reforma, los AR alcanzaban el 75\% del total de Salidas Alternativas alcanzadas por los imputados ingresados a la Defensoría Penal (en las Salidas Alternativas se incluye a la Suspensión Condicional del Procedimiento y los Acuerdos Reparatorios), porcentaje que fue disminuyendo cada año, y en el año 2007, los AR no superaban el 13,1\% del total de salidas alternativas, en tanto que la SCP representaba el $86,9 \%$ de éstas.

Esto nos indica, en principio, que algunos elementos propios de la justicia restaurativa, como la reparación del daño a la víctima, que sea el resultado de un acuerdo entre quienes son directamente afectados por la comisión del delito, sí estarían operando de manera importante en Chile a través de los acuerdos reparatorios, por lo que, si bien la mediación penal, al menos la directa, aún no tiene un desarrollo significativo, la justicia consensuada, y con ella algunos elementos restaurativos, sí estarían aplicándose.

\subsection{Chile en un período de Reformas a la Justicia.}

Desde otra perspectiva, es importante considerar que este país se ha embarcado en una profunda reforma a su sistema de justicia penal, cambiando desde un procedimiento inquisitivo, secreto y escrito, a un proceso acusatorio, oral y público, siendo tal vez la reforma de este tipo más exitosa que se ha llevado a cabo en Latinoamérica, como lo han señalado muchos actores y a juzgar también por las demandas de intercambio y

\footnotetext{
${ }^{130}$ Elaboración personal realizada en el año 2005, con la colaboración de la División de Informática del Ministerio Público.

131 Informe Estadístico Anual de la Defensoría Penal Pública, 2007, en http://www.defensoriapenal.cl/interior/estadisticas/2007/informe-estadistico-anual-2007.pdf
} 
Polít. crim. Vol. 5, No 9 (Julio 2010), Art. 1, pp. 1-68.

[http://www.politicacriminal.cl/Vol_05/n_09/Vol5N9A1.pdf]

capacitación que llegan a Chile desde diversos países latinoamericanos, ${ }^{132}$ todo lo cual supone a actores intervinientes en el proceso penal comprometidos con los valores que promueve esta justicia adversarial. La justicia restaurativa critica los principios y valores de la justicia adversarial y retributiva, de manera que esto puede explicar que sea difícil para estos nuevos actores acoger y suscribir a los valores sustentados por la justicia restaurativa, y ello permita explicar el particular desarrollo que ésta ha tenido hasta ahora.

Sin embargo, el escenario es más complejo, como lo demuestran el desarrollo de los AR, su relevancia en el conjunto del sistema, y los intentos que ha habido también desde los operadores de la justicia penal para implementar proyectos de mediación penal.

En este sentido, resulta interesante citar las palabras del experto en mediación penal, el norteamericano Marty Price, que visitó Chile en el año 2006 invitado por el Ministerio de Justicia de Chile, para promover, difundir y capacitar a los actores en Chile acerca de la mediación víctima-infractor (el modelo VORP):

"La importancia del movimiento de "Reformas a la Justicia" (Justice undergoing Change) en Sudamérica no debe ser subestimado. Tanto Argentina como Chile están en un período de profundas transformaciones a sus sistemas legales, transitando de cientos de años de haber tenido un procedimiento penal inquisitivo a tan sólo unos pocos años de procedimiento penal adversarial como el que siempre hemos tenido en Estados Unidos......Si bien no resulta accidental que yo haya sido invitado a Argentina y Chile durante el período de "Reformas a la Justicia", también me pareció algo irónico que fuese así. En Norteamérica, el movimiento de justicia restaurativa arribó, al menos en parte, en respuesta a las inequidades, injusticias e ineficiencias de nuestro sistema adversarial de justicia penal. En Argentina y Chile, los fiscales y defensores son percibidos como "una brisa de aire fresco", los custodios y proveedores de un sistema de justicia penal adversarial más moderno y democrático (el sistema de jurado aún no se implementa).

Debido a que el sistema adversarial que funciona con fiscales y defensores penales públicos es "la nueva vía" (y sin duda representa un gran avance en relación al sistema anterior), yo inicialmente imaginé que mi mensaje restaurativo, que proclama la sanación de las personas y las relaciones, por sobre la visión estrecha de "ganar el caso" que posee el enfoque adversarial, sería recibido con una gran resistencia. Pero para mi grata sorpresa, descubrí que la novedad de la "adversarialidad", en el contexto del espíritu de "Reformas a la Justicia", estimulaba la apertura hacia las nociones subyacentes a la justicia restaurativa...En mi mente, contrasté esa apertura con la resistencia al movimiento de justicia restaurativa que ha sido típico de Estados Unidos y otros países que llevan siglos de justicia penal adversarial. Los sudamericanos están en pleno período de cambios, sienten que es algo que se debió hacer desde hace mucho tiempo atrás, les gusta y quieren más. Parecen ver a la justicia restaurativa como una manera más de seguir modernizando y "democratizando" su manera de

\footnotetext{
${ }^{132}$ Ver, sólo como ejemplo, la actividad que en este sentido desarrolla la institución chilena CEJA, en
} http://www.ceja.org 
DÍAZ, ALEJANDRA. "La experiencia de la mediación penal en Chile".

hacer justicia penal, y de introducir aún más equidad y eficiencia en ella - por la cual están hambrientos- o simplemente, de hacer una justicia 'más justa'",133

Estas palabras captan, al menos desde uno de sus posibles ángulos, la complejidad del desarrollo de la justicia restaurativa y la mediación penal en Chile, la cual está plagada de matices y desafíos, conectados a estructuras y procesos socio-políticos, culturales y visiones más profundas que vive la sociedad chilena en su conjunto, como parte, además, de una sociedad globalizada que se ve afectada por los fenómenos y procesos que atraviesa el Estado y la sociedad civil tanto en la región latinoamericana como en el mundo o, por lo menos, en el mundo occidental. Pero también, que tienen su propia expresión y manifestación en la cultura y realidad local.

\section{Conclusiones}

Jurídicamente, la posibilidad de incorporar la justicia restaurativa y la mediación penal en Chile se dio, primero, en el ámbito de los ofensores adultos, a través, principalmente, de las salidas alternativas y el principio de oportunidad introducidos en el marco de la Reforma Procesal Penal en el año 2000. Sólo posteriormente, con la reforma al sistema de justicia juvenil en Chile en el año 2007, se abrió la posibilidad de incorporarlas también con jóvenes ofensores, pero ya no sólo como salidas alternativas o "diversión", sino que también en la fase de sentencia, a través de las nuevas sanciones de contenido reparatorio.

Si bien la institución de los acuerdos reparatorios puede considerarse una manifestación de justicia restaurativa, ella no ha implicado un desarrollo importante de la mediación penal en Chile, que supondría por sí misma un avance mayor de justicia restaurativa al hacer posible la inclusión del valor de "encuentro personal" entre las partes directamente afectadas por el delito, valor al que hacen alusión los autores Van Ness y Strong como un aspecto central en la justicia restaurativa.

Varias pueden ser las razones de este escaso desarrollo, como se vio a lo largo de este trabajo, desde motivos de gestión y razones de costo-eficiencia para los nuevos actores de la reforma procesal penal, hasta cuestiones culturales, y por último, debilidad y/o insuficiencia de políticas públicas al respecto. Si bien lo novedoso de la Reforma Procesal Penal pudiera, en un principio, constituirse en un obstáculo al desarrollo de la justicia restaurativa en Chile, ello no es necesariamente así, pues como lo ha señalado el autor Marty Price, pareciera ser que el "espíritu de reformas" alcanza también para la justicia restaurativa.

Por otro lado, resulta interesante esperar que la justicia restaurativa no surja necesariamente desde el Estado, como una política pública "desde arriba", sino que surja también como una

\footnotetext{
${ }^{133}$ Traducción libre de la autora, de un extracto del artículo del autor PRICE, Marty "Restorative Justice Speaking Tour in Argentina and Chile", Justice Connections, $\mathrm{N}^{\circ}$ 2, Otoño 2006, pp. 8-9, en http://www.voma.org/docs/connections2.pdf [visitado el 08.04.2009].
} 
Polít. crim. Vol. 5, No 9 (Julio 2010), Art. 1, pp. 1-68.

[http://www.politicacriminal.cl/Vol_05/n_09/Vol5N9A1.pdf]

fuerza "desde abajo", de la sociedad civil y la comunidad, y en donde la política pública cumpla un rol más bien de apoyo a la sociedad civil.

Por último, cabe señalar que algo de "restaurativo" ya está y ha estado desde siempre en nuestra sociedad, pues, como señala el criminólogo australiano John Braithwaite: ${ }^{134}$

"Todavía no he descubierto una cultura que no tenga algunas tradiciones restaurativas profundamente enraizadas en ella. Tampoco hay una cultura sin tradiciones retributivas. Las tradiciones retributivas eran útiles para la sobrevivencia. Las culturas que eran tímidas en responder o atacar, eran frecuentemente eliminadas por culturas más decididamente violentas. En el mundo contemporáneo, a diferencia del mundo de nuestros ancestros, las emociones retributivas tienen menor valor para la sobrevivencia. Debido a que el manejo del riesgo se ha institucionalizado en nuestro mundo moderno, las emociones retributivas tienen más posibilidades de meternos en problemas que en sacarnos de ellos, tanto como individuos, grupos y naciones". ${ }^{135}$

En verdad, las habilidades para negociar, persuadir, convencer, agrupar y reintegrar, parecen ser hoy más predictoras de sobrevivencia (y de éxito) que las de la retribución, el "ganar-perder" y el mirar al "otro" como un enemigo al que hay que vencer.

Si ello es así, si hay valores restaurativos en la cultura legal chilena y si, además, ellos son más útiles para nuestra sobrevivencia que los valores retributivos, lo "nuevo" en Chile sería la institucionalización de estas prácticas y/o valores; el que se instalen como una respuesta central de la sociedad frente al delito. El escenario que vive Chile en términos de justicia restaurativa, es interesante, no porque ella esté consolidada, sino precisamente por lo que es, un proceso en formación, y por el particular período histórico que vive Chile de "reformas a la justicia" y los desafíos que ello conlleva.

\section{BIBLIOGRAFÍA}

ABARCA, A., "Resolución Alternativa de Conflictos en el área familiar", Revista Crea, $\mathrm{N}^{\circ} 1$ (2000), pp. 150-61.

AIMONE, D. "Análisis de la Procedencia de la Mediación en el Nuevo Sistema Procesal Penal", La Semana Jurídica, No 195 (2004).

BARROS, L., Justicia y Marginalidad Rural, DESUC, Santiago: CDJ-CPU, 1994.

\footnotetext{
${ }^{134}$ BRAITHWAITE, cit. nota ${ }^{\circ} 2$, p. 331.

${ }^{135}$ Traducción libre de la autora. En inglés: "I have yet to discover a culture that does not have some deepedseated restorative traditions. Nor is there a culture without retributive traditions. Retributive traditions once had a survival value. Cultures that were timid in fighting back were often wiped out by more determinedly violent cultures. In the contemporary world, as opposed to the world of our biological creation, retributive emotions have less survival value. Because risk management is institutionalized in the modern world, retributive emotions are more likely to get us into trouble than out of it, as individuals, groups, and nations"
} 
DÍAZ, ALEJANDRA. "La experiencia de la mediación penal en Chile".

BASCUÑÁN, A., "El Concepto de Derecho y el Problema de las Fuentes del Derecho. Rol Expresivo e Instrumental del Derecho en la Sociedad", en: SQUELLA, A. (Ed.), La Cultura Jurídica Chilena, Santiago: CPU, 1988, pp. 55- 66.

BAZEMORE, G.; WALGRAVE, L., Restorative Juvenile Justice: Repairing the Harm of Youth Crime, Monsey: Criminal Justice Press, 1999.

BLANCO, R.; DIAZ, A.; HESKIA, J.; ROJAS, H., Justicia Restaurativa: Marco Teórico, Experiencias Comparadas y Propuestas de Política Pública, Santiago de Chile: Universidad Alberto Hurtado, 2004.

BRAITHWAITE, J., Crime, Shame and Reintegration, Cambridge: Cambridge University Press, 1989.

BRAITHWAITE, J., "Restorative justice" en: TONRY, Michael (Ed.) The Handbook of Crime and Punishment, Oxford: Oxford University Press, 1998, pp. 323-44.

BURGOS, J., "Centro de mediación de Santiago "experiencia y desafíos futuros", Revista CREA, No3 (2002), pp. 185-90.

CAMPOS, H., "Reflexiones en torno a la incorporación de estrategias restaurativas en nuestro país" Ponencia presentada en III Encuentro Iberoamericano de Resolución Alternativa de Conflictos, Viña del Mar, 22 al 24 de Septiembre de 2004, en: http://www.redesalternativas.com/notas.htm

CARNEVALI, R., "Las políticas de orientación a la víctima examinadas a la luz del Derecho Penal", Revista de Derecho de la Pontificia Universidad Católica de Valparaíso, XXVI, Semestre I (2005), pp. 27-39.

CORMIER, R., "Basic Principles on the Use of Restorative Justice Programmes in Criminal Matters", Ponencia presentada en la Fourth International Conference on Restorative Justice for Juveniles, Tübingen, Germany, October 1-4, 2000.

CORPORACIÓN DE ASISTENCIA JUDICIAL R.M. Resolución Alternativa de Conflictos: Una opción democrática de acceso a la justicia. Una forma de intervención humanizante en la Asistencia Jurídica Gratuita, Santiago: Editorial Jurídica de Chile, 2003.

COX, S.; SALGADO, C. "Resolución alternativa de conflictos en América: Chile", Resolución Alternativa de Conflictos, Revista $\mathrm{N}^{\circ} 2$ (2001), en: http://www.cejamericas.org/sistemas-judiciales

CORREA, J.; JIMENEZ, M.A.; LEÓN MONCAYO, H.; Equipo de investigadores del IBAM, Acceso de los pobres a la justicia en países de América Latina. PNUD, Colección Estudios Urbanos, Ed. SUR, 1995.

CORREA, J.; JIMENEZ, M.A., Sistema Judicial y Pobreza. Estudio sobre el acceso a la justicia, Cuadernos de Análisis Jurídico No 35, Serie Seminarios, Santiago de Chile: Universidad Diego Portales, 1997.

COUSO, J., "La política criminal para adolescentes y la Ley 20.084", Documento de Trabajo, Unidad de Defensa Penal Juvenil, Defensoría Penal Pública, Santiago de Chile, 2008.

CRAWFORD, A., "Justice de Proximité - The Growth of "Houses of Justice and Victim/Ofender Mediation in France: A Very Un French Legal Response?", Social and Legal Studies, Vol. 9, № 1 (2000), pp. 29- 53.

CHRISTIE, N., "Conflicts as property", The British Journal of Criminology 17 (1) (1977), pp. 1-14. 
Polít. crim. Vol. 5, No 9 (Julio 2010), Art. 1, pp. 1-68.

[http://www.politicacriminal.cl/Vol_05/n_09/Vol5N9A1.pdf]

DAPENA, J.; MARTÍN, J. "La mediación penal juvenil en Cataluña. España”, Estudio de la Dirección General de Medidas Penales Alternativas y de Justicia Juvenil, Barcelona, 1998, en: http://www.restorativejustice.org

DÍAZ, A., "La Influencia del Movimiento Pro-Víctimas en la Justicia Restaurativa", Revista CREA, Vol. 4 (2003), pp. 195-212.

DÍAZ, A., "La Mediación Penal y los Acuerdos Reparatorios: Potencialidades de Aplicación y Principios Involucrados", Ponencia presentada en III Encuentro Iberoamericano de Resolución Alternativa de Conflictos, Viña del Mar, 22 al 24 de Septiembre de 2004, en: http://www.redesalternativas.com/notas.htm; http://www.restorativejustice.org

DÍAZ, A., "Justicia Restaurativa: Concepto y Modelos Prácticos", Boletín Jurídico, Ministerio de Justicia, Santiago de Chile, 2004.

DÍAZ, A., "The Growth of an Internacional Restorative Justice Movement: Some Implications for Juvenile Justice in Chile", Phd Thesis, University of Leeds, 2004, The British Library, Dewey class. no. 345.8308 22, en: The British Library Electronic Online System (EThOS) http://ethos.bl.uk/ViewTerms.do 416554

DÍAZ, A., "Los servicios en beneficio de la comunidad y la prevención de la reincidencia: enseñanzas de las experiencias comparadas", Ponencia presentada en Seminario Justicia Juvenil: una Visión Restaurativa, Santiago de Chile, 17 y 18 de Noviembre de 2008, en: http://www.restorativejustice.org, accesible el 1 de abril de 2009.

DUCE, M., "La Suspensión Condicional del Procedimiento y los Acuerdos Reparatorios en el Nuevo Código Procesal Penal", en: CAROCCA, A.; DUCE, M.; RIEGO, C.; BAYTElmAN, A.; VARGAS, J.E., El Nuevo Proceso Penal, Cuadernos de Trabajo $\mathrm{N}^{\circ}$ 2, Santiago: UDP, 2000, pp. 139-171.

ELÍAS, R., "Community Control, Criminal Justice and Victim Services", en: FATTAH, E.A. (Ed.) Towards a Critical Victimology, London: The Macmillan Press, 1992, pp. 373-395.

FRIEDMAN, L., "Justicia restaurativa. Nuevas formas de tratamiento para delincuentes juveniles", 2007, en: http://www.cienciaspenales.net

FUNES, J., Mediación y Justicia Juvenil, Barcelona: Fundación Jaume Callís, 1995.

GONZÁLES, I.; CASTILLO, A.D.; DE LAS HERAS, M.J., "Mediación penal y justicia restaurativa en Chile", 2006, en http://www.accesoalajusticia.cl/webjusticia/nuevos/docs/mediacionpenalyjusticiaII.p $\underline{\mathrm{df}}$, accesible en Diciembre de 2008.

HORWITZ, M. I.; LÓPEZ, J., Derecho Procesal Penal Chileno, Tomo I, Santiago de Chile: Editorial Jurídica, 2002.

JIMÉNEZ, M.A. (Dir.); SANTOS, T.; HERMOSILlA, G.; SCALIA, P., Las salidas alternativas en el nuevo proceso penal. Estudio exploratorio sobre su aplicación. Santiago de Chile: Centro de Documentación Defensoría Penal Pública, 2004.

KREBS, R., "Prólogo" en: GÓNGORA, M., Ensayo Histórico sobre la Noción de Estado en Chile en los Siglos XIX y XX, Colección Imagen de Chile, Santiago: Ed. Universitaria, 1998, pp. 45-58.

LAGOS, S., "Experiencias de Mediación Penal", Ponencia presentada para el Seminario La mediación, instrumento de paz social en distintos ámbitos: penal, laboral, familiar e infancia, Temuco, 21 de noviembre de 2003. 
DÍAZ, ALEJANDRA. "La experiencia de la mediación penal en Chile".

LILLO, R., "Conflictos ambientales en territorios indígenas", Revista CREA, №2 (2002), pp. $70-112$.

LÓPEZ, J., "Formas Alternativas de Resolución de Conflictos en la Ley Indígena 19.253", Revista CREA, №2 (2002), pp. 77-85.

MARSHALL, T.F., Restorative Justice. An Overview. Home Office, 1999.

MATUS, J.P., "La justicia penal consensuada en el nuevo Código de Procedimiento Penal", Revista CREA, No 1 (2000), pp. 122-143.

McCOLD, P.; WACHTEL, T., "Restorative Justice Theory Validation", ponencia presentada en la Fourth International Conference on Restorative Justice for Juveniles, Tübingen, Alemania, 1 a 4 de October de 2000. Versión en español: "En busca de un paradigma, una teoría sobre justicia restaurativa", Revista EForum, Agosto 12 (2003), en: http://www.restorativepractices.org

MORALES, A.M., "Las salidas alternativas y las sanciones no privativas de libertad de reparación del daño y servicios en beneficio de la comunidad en el subsistema de responsabilidad penal de adolescentes infractores de la ley penal", Revista de Estudios de la Justicia - REJ-, No 7 (2006), pp. 159-182.

PARKER, L., "El uso de prácticas restauradoras en América Latina", Revista CREA, №4 (2003), pp. 217-242.

PEÑA, C., "Hacia una Caracterización del Ethos Legal: de Nuevo sobre la Cultura Jurídica" en: Squella, A. (Ed.) Evolución de la Cultura Jurídica Chilena, Santiago: CPU, 1994, pp. 23-149.

PRICE, M., "Restorative Justice Speaking Tour in Argentina and Chile", Justice Connections, Issue 2, Fall 2006, pp. 8-9, en: http://www.voma.org/docs/connections2.pdf (consultado el 8 de abril de 2009)

PURCELL, C.; ARRUE, A.P.; MUÑOZ, C.G., "Investigación exploratoria acerca del proceso y resultados de la aplicación de la mediación como técnica alternativa de resolución de conflictos en el ámbito judicial”, Revista CREA, №2 (2001), pp. 204212.

SUÁRES, M., Mediación, conducción de disputas, comunicación y técnicas. Buenos Aires: Paidós, 1997.

SQUELLA, A. (Ed.), La Cultura Jurídica Chilena, Santiago: CPU, 1992.

SQUELLA, A., "Documento Base del Seminario sobre la Cultura Jurídica Chilena. La Cultura Jurídica Chilena", en: Squella, A. (Ed.) La Cultura Jurídica Chilena, Santiago: CPU, 1992, pp. 9-48.

SQUELLA, A., "Documento de Síntesis del Seminario sobre la Cultura Jurídica Chilena. Síntesis del Desarrollo del Seminario", en: SQUELLA, A. (Ed.), La Cultura Jurídica Chilena, Santiago: CPU, 1992, pp. 127-159.

SQUELLA, A., "La Cultura Jurídica Chilena: Antecedentes, Estado Actual y Proyecciones de una Discusión", en: SQUELlA, A. (Ed.), Evolución de la Cultura Jurídica Chilena, Santiago: CPU, 1994, pp. 7- 21.

TSUKAME, A., "Mediación y Responsabilidad Penal del Adolescente", Ponencia presentada en III Encuentro Iberoamericano de Resolución Alternativa de Conflictos, Viña del Mar, 22 al 24 de Septiembre de 2004, en: http:// www.redesalternativas.com/notas.htm 
Polít. crim. Vol. 5, № 9 (Julio 2010), Art. 1, pp. 1-68.

[http://www.politicacriminal.cl/Vol_05/n_09/Vol5N9A1.pdf]

ULLOA, M., "Los sistemas alternativos de resolución de conflictos", Ponencia presentada en el Colegio de Abogados de Concepción, Septiembre de 1998.

VARGAS, J.E., "Problemas de los sistemas alternos de resolución de conflictos como alternativa de política pública en el sector judicial", Resolución Alternativa de Conflictos, №2 (2001), en: http://www.cejamericas.org/sistemas-judiciales

VARGAS, M., "Mediación familiar en Chile. La experiencia del Programa de Resolución de Conflictos anexo a Tribunales", Resolución Alternativa de Conflictos, №2 (2001), en: http://www.cejamericas.org/sistemas-judiciales

VARONA, G., La mediación reparadora como estrategia de control social. Una perspectiva criminológica, Granada: Editorial Comares, 1998.

VIAL, P., "La justicia restaurativa y la justicia juvenil en Chile: Una perspectiva desde la Defensoría Penal Pública", Ponencia presentada en Seminario Justicia Juvenil: una Visión Restaurativa, Santiago de Chile, 17 y 18 de Noviembre de 2008.

WALGRAVE, L., "Extending the Victim Perspective Towards a Systemic Restorative Justice Alternative" en: CRAWFORD, A.; GOODEY, J. (Eds.), Integrating a Victim Perspective Within Criminal justice: International Debates, Aldershot: Ashgate, 2000, pp. 253-83.

VALENCIA, A.; DÍAZ, A., "El proyecto 'Centro de Resolución Alternativa de ConflictosCREA", Revista CREA, No1 (2000), pp. 7-9.

VAN NESS, D.; STRONG, K.H., Restoring Justice, Cincinnati, Ohio: Anderson Publishing, 1997.

ZEHR, H., Changing Lenses: A New Focus for Crime and Justice, Pennsylvania: Herald Press, 1990. 